SILAGE INVESTIGATION

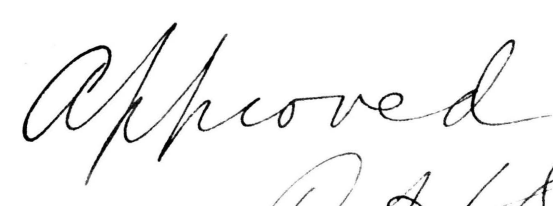

by

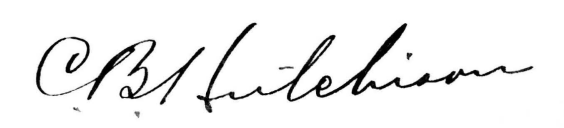

Albert Lark Darnell, B. S. in Agr.

SUBMITTED IN PARTIAL FULPIIAENT OF THE

REQUIRENENTS FOR THE DEGREE OF

MASTER OF ARTS

in the

GRADUATE SCHOOI

of the

UNIVERSITY OF MISSOURI

1916. 
1. Introduction ..................... Page

2. Review of Iiterature: . . . . . . . . . 4

Factors Influencing Acidity in Silage . . . . . 5

Losses in Silage . . . . . . . . . . 12

Legumes for silage . . . . . . . . . . 23

Shock Corn Silage . . . . . . . . . . 30

Silage from other Crops . . . . . . . . 34

Weight of silage per Cubic foot ....... 36

Influence of Mould upon Composition of silage. • • 42

3. Experimental Methods . . . . . . . . . . 44

Description of silos . . . . . . . . . 44

Taking Samples . . . . . . . . . . 45

Moisture Determination .......... . 46

Acidity Test . . . . . . . . . . 46

Chemicsl Analyses. . . . . . . . . . 47

sugar Determination............ . 47

Method of Taking Weights . . . . . . . 4 47

4. Factors Influencing Acidity. . . . . . . . 49

5. Iosses in the silo............ 58

6. Legumes for silage . . . . . . . . . . 75

7. Shock Corn Silage . . . . . . . . . 81

8. other crops for silage . . . . . . . . . 86

9. Weight of Silage per Cubic Foot . . . . . . 92

10. Influence of Mould upon Composition of Silage . . . 106

11. Conclusions . . . . . . . . . . . . 111

12. Bibliography . . . . . . . . . . . 115

14138159 


\section{SIIAGE INVESTIGATION.}

\section{INTRODUCTION.}

The practice of preserving green feeds in silos dates back about one hundred and thirty years. Accord1

ing to simonds, it was a common practice in Italy to preserve fresh leaves for cattle, in pits, or in casks, above ground, as early as 1786. Possibly the first article on the preservation of green feeds in silos was written by Johnston, an Anglishman, in 1843. The practice of storing green maize in silos was probably begun in 1869, when Adolph Reihlen, a sugar manufacturer of stuttgart, Germany, stored in a silo, a crop of corn of the large yellow dent variety. The results of his work were published in both German and French in 1870, which led many farmers in France to build silos. A. Goffart, in 1877 wrote, perhaps the first book on "ensilage" which was translated into finglish and published a few years later in New York.

1. U. S. Dep't. of Agriculture, Bul. No. 32,pp7. 
The first silage made in the United States was put up by Manly Miles of Michigan, who built two silos in 1875 and filled them with small grain and hay. From this beginning the silo has spread rapidly; due,first, to the fact that it prevents waste of a portion of the forage that would otherwise be lost, and converts it into palatable food; secondly, it is the most economical method of supplying succulent feed during the winter and the hot dry periods of summer.

At the present time the silo is found on many thousand farms in the United States, especially in dairy regions, and it may be considered a well-established fixture in American farm economy, where stock feeding is practiced.

The first work with silage along experimental

lines was probably conducted by Francis Morris of Maryland, in 1876. From this date to the early part of the twentieth century considerable work was carried out. After 1902, little work was done along this line until very recently. At the present time various phases of the subject are under investigation bj several experiment stations.

The work at the Missouri Experiment station 
was begun in 1913. The work for that year was conductod by D. G. Magruder. The work for 1914-15 was a continuation of that begun in 1913 and was carried on by 0. I. 0shel. The investigations during 1915-16 have been conducted by the present writer and were designed to continue and supplement the investigations of the previous years. The scope of the investigation reported in this thesis may be considered as an attempt to answer the following questions by experimental methods: 1. What are the factors affecting acidity in silage?

2. What is the percentage loss in the silo as compared with shocking corn in the field?

3. What are the possibilities of making silage from the legume crops?

4. What is the percentage loss when shock corn is put in the silo, and is there a normal acidity developed in silage from shock corn?

5. Is it possible to make silage from the small ceral crops, and from the non-saccride sorghum?

6. What are the factors affecting the weight of a cubic foot of silage at different depths?

7. What is the offect of mould upon the composition of Bllage? 


\section{IITERATURE.}

Finsilage as defined by Webster is the material as it appears while being put into the silo. Immediately after the material is stored it begins to undergo physical, chemical and bacterial changes, that continue for about fourteen days, at which time the material is known as silage. Thus silage formation includes all the physical, chemical and bacterial changes which take place in the silo the first fourteen days after being filled.

At the present time there are two views held as to silage fermentation: one, that it is due to the action of bacteria, the other, that it is due to the intra-molecular respiration of the cells. The former view is supported by several experiment stations: Pernot, Whitcombe and Kinsley of the Oregon Experiment Station, and Esten and Mason of the storrs Experiment station, being the strongest supporters. 3 Hart, Willaman, Babcock and Russell of the Wisconsin Experiment station, and ${ }^{5}$ E. J. Russell of the Rothamstead Experiment station in Fngland, support the latter view. The larger mass of evidence seem to oupport the intra-molecular theory.

1. Ore. Exp.sta.Rpt., 1902, pp.68-69; Bul. 72.

2. Storrs Exp.Sta.; Bul. No. 70, 19i2, pp.12-14.

3. Jaur, Amer Chem. Soc. . 34 (1912) No.11, pp.1619-1625.

4. Chem. News, $70(1894)$ pp.273-275.

5. Jour Agr. So1.2(1908). No. 4, pp. 395-410. 
FACTORS INFLUENCING ACIDITY IN SIIAGE.

As a result of work on silage fermentation for 1

three years at the Storrs Station, Connecticut, Esten and Mason pointed out that there is a thin film of juice surrounding each piece of silage which affords an ideal media for the growth of sugar fermenting yeast and bacteria, which begin to grow as soon as the silage enters the silo. The work of the bacteria in changing the sugar to acid is continued for a time until the lactic acid bacteria cease to work, then the yeast completes the fermentation of the remaining sugar.

The alcohol produced is immedictely acted on by acetic bacteria and changed to acetic acia.

The factors aiding these changes, as pointed out by authors, are, proper temperature, lack of air in the silage, and symbiosis. Acid bacteria need a temperature not lower than $60 \mathrm{~F}$ but grow much better at tempatures from $70 \mathrm{~F}$. to $90 \mathrm{~F}$. Yeast work better at a tempature between $70^{\circ} \mathrm{F}$. and $90^{\circ} \mathrm{F}$.

The Illinois Experiment station reports the

1. Storrs Expt. Sta. Bul. 70

2. IIl. Exp. Stc. (1888) Bul. 2. 
presence of Bacterium aceti, Bacterium lactis, and Spirillum postorianus in samples of silage. Amounts of acid found in three samples were $1.99 \%, 2.27 \%$, and 2.44\%. Clover silage fifteen days old had .038\% acetic acid, . $865 \%$ lactic acid or a total of $.903 \%$. Green wheat silage twenty-eight days old had . $338 \%$ acetic and $1.20 \%$ lactic, or a total of $1.53 \%$ acid. 1 Whitcombe and Kinsley of the Oregon Station found that corn silage, after being steamed in the silo, underwent very little fermentation. However, the fermenting organisms in silage from legume crops seemed to be more resistant agkinst heat, as there was more fermentation in silage from these crops than from corn. The acidity of silage not steamed varied from $1.01 \%$ to $1.94 \%$ and averaged $1.58 \%$. The acidity of the steamed silage varied from $30 \%$ to

$.88 \%$ and averaged $.55 \%$

Short, of Wisconsin, showed that as corn becomes more mature, it contains less water and produces silage with a lower per cent of acid. The higher the per cent of moisture in the silage, greater is the per cent of acid, as shown in the following table:

1. Ore. Expt. Sta. Bul. 72.

2. Wis. Exp. Sta., Bul. 19, pp. 20. 


\begin{tabular}{lcccc}
\hline \hline & & & \\
& & & \\
Variety of Corn: Percent of Moisture & Percent of Acid. \\
\hline Flint & $\vdots$ & 39.85 & $\vdots$ & 0.53 \\
\hline Flint & $\vdots$ & 40.89 & $\vdots$ & 0.66 \\
\hline Flint & $\vdots$ & 41.20 & $\vdots$ & 0.67 \\
\hline Dent & $\vdots$ & 38.13 & $\vdots$ & 0.43 \\
\hline Dent & $\vdots$ & 78.00 & $\vdots$ & 1.42 \\
\hline Dent & $\vdots$ & 80.00 & $\vdots$ & 1.64 \\
\hline Evergreen & $\vdots$ & 77.90 & $\vdots$ & 1.31 \\
\hline Evergreen & $\vdots$ & 68.30 & $\vdots$ & 0.98 \\
\hline B\& W & $\vdots$ & 82.00 & $\vdots$ & 1.16 \\
\hline B \& W & $\vdots$ & 79.00 & $\vdots$ & 0.81 \\
\hline B \& W & $\vdots$ & 45.00 & $\vdots$ & 0.53 \\
\hline Sheep's Tooth & $\vdots$ & 75.35 & 1.26 \\
\hline
\end{tabular}

1 King, of the same station found that when water was added to the silo while being filled, a high per cent of acid was developed in the silage and there was not 2 great loss by the action of undesirable ferments. Whitcombe confirms King's results. He found that

1. Wis. Exp. Sta. 10th. Ann. Rpt. pp. 211-227.

2. Ore. Exp. Sta. Bul. 67. pp. 104. 
both corn and legume silage with a low per cent of dry matter had a correspondingly high per cent of acid. However, the silage made from the legumes did not give as good results as did the corn, the tendenoy being toward a lower per cent of acid when there is an excess of moisture. 1 Morse, of the New Hamphire Station found that the percentage acidity in silage varied with the variety of corn,for example: The average acidity of silage made from the leaming variety of corn was $.67 \%$, that made from the Mosby Prolific averaged . $83 \%$, while that made from the Sanford variety averaged $1.95 \%$. Morse also found that there was a lower per cent of acid at the surface of the silage after standing a few hours than there was six inches below the surface, the percentages being $.83 \%$ and $1.3 \%$ respectively, calculated as acetic acid. The Massachusetts Experinent station reports a high per cent of acid with a correspondingly low per cent of dry matter. 3

Babcock and Russell, of Wisconsin, claim that acid formed in silage is due to the intra-molecular resipration of the plant tissues, hence silage made from

1. N. H. Exp. Sta. Bul. 96, pp. 115.

2. Mass. Exp. Sta. Bu. 36, (1890).

3. Chem. News 70(1894), pp. 273-275. 
corn in the milk stage, having more active cell tissue, will develop more acid than that made from more mature corn. They also pointed out that carbon dioxide has something to do with the development of acid, as it kills the plant tissue, thus checking the intra-molecular respiration.

1

Hart and Willaman, of the same Station are of the opinion that the acidity of silage is caused by anaerobic respiration of the living cells within the tissues, rather than by means of foreign organisms. Their decision was based upon the fact that grinding the silage very fine with a meat grinder liberates more acid than by chopping with a knife. Dox and Neidig, of the Iowa station conducted an experiment to show the rate of formation of lactic acid in silage. Samples were taken each day for fourteen days. They were taken with a two inch soil auger through holes in the door, after which the holes were carefully sealed. The greatest formation of lactic acid and volatile acids occurred between the first and fourth day. The ratio of lactic to volatile acids as an average of all samples was 1.0 to $0.75 .{ }^{3}$ Neidig, a few years later, with other experiments on silage

1. Jour. Amer. Chem. Soci. 34(1912) No. 11, pp. 1619-1625.
2. Iowa Exp. Sta. Res. Bui. No. 10.

3. Iowa Exp. Sta. Res. Bul. No. 16. 
showed with three different types of silos the relation between the sugar content of the corn and the acid of the silage made therefrom. He took samples from a silo (as previously described) at frequent intervals for two weeks. He found that from the time of filling, there was a gradual increase in the amount of volatile acids (acetic and propionic) as well as a gradual increase of the non-volatile acid (lactic). There was a trace of butyric and valeric acids in some cases at the beginning, but disappeared in a few days. From the time of filling the silos the sugar decreased in amount until a minimum was reached in about three weeks. In no instance did the reducing sugars disappear completely.

1 Griffith found with acid silage produced from clover, at temperatures of $32^{\circ} \mathrm{C}$. to $49^{\circ} \mathrm{C}$., the volatile acids were; from very immature forage, 1.19\%; from plants just in bloom, $0.38 \%$. The non-volatile acids were respectively, $0.31 \%$ and $0.23 \%$ The silage was more acid from immature than from older plants. 2 Kedzie demonstrates with corn out when in full tassel and in first stage of silk made silage with 1.26\% acid. Silage made from corn cut at intervals of one week from the first cutting in August to the last

1. Chem. News, 70(1894), No. 1828, pp. 273-275.

2. Mich. Exp. Sta. Buz. 68. (1890) pp. 10. 
cutting in september, when the corn was in the glazed stage and some of the older stalks with hard ears, showed a constant decrease in the amount of acid contained, from $1.26 \%$ in August to $.70 \%$ in september. This is (as previously pointed out) due to the greater functional activity of the plant cells in the early stages. During this period the tissues are not only richer in protoplasm but are more active and hence the amount of fermentative changes which take place in the dying of the cells is greater than in those stages where the tissues are much more mature. 1 Magruder, in his work at this Station, shows that the per cent of acid at the wall and in the center of the silo varies, the difference being $1.8 \%$ and 2.1\% respectively. He also showed that there is a normal amount of acid developed in silage made from shock corn when water is added in the ratio of $1: 1$. Where 6.25 pounds of water was added to every twenty pounds of fodder the silage produced had only $.76 \%$ of acid. With other proportions of water and fodder he found the acid to increase in direct proportion to the water added. In siloing green corn as compared with the more mature

1. Thesis, "Silos and Silage", Univ. Mo. 1914. 
corn he obtained the same results reported by various other experiment stations; that is a higher per cent of acid in silage made from immature corn. 1 Oshel showed that the high per cent of acid in silage made from imnature corn is not necessarily due to a high moisture content, but suggests the amount of sugar present. This he showed by siloing crops with different sugar content, in small silos. However, he claimed that all of the acid developed is not due to direct fermentation of sugar, but must be due to some other agent, as show in the case of alfalfa silage which developed $2.05 \%$ of acid, as compared with corn which developed $2.58 \%$ acid. He also pointed out that the more air present in silage, the lower the per cent of acid developed.

IOSSES IN SIIAGE.

The fermentation of an organic body is always accompanied by a loss of substance, the amount destroyed depending upon the extent of the fermentation. The greater the fermentation, the higher the temperature runs in the silo, and it is a well established fact that silage formation is accompanied by a high temperature. It is easily seen therefore, that under the conditions which

1. Thesis, "Silage Investigations" for the Degree of A.M., Univ. of Mo., 1915. 


\begin{abstract}
exist in the silo we must expect a loss of dry matter, and that the higher the teimperature in the silo, the greater will be the 10ss. This 10ss, as indicated by various experiment stations, ranges from $2 \%$ to $31 \%$; none, so far, reporting a smaller loss than $2 \%$. 1 Early work along this line carried on at the Wisconsin Experinent station showed a loss of from 14.7\% to $31.81 \%$. The Arkansas station reported a loss of $13.7 \%$ to $27.8 \%$ in total weight, and results obtained by Armsby showed a 10 ss of $22.9 \%$ to $43.48 \%$ in total nutrients. All of these results include the loss from mouldy silage as well as what mechanical losses that might have occurred. 4 Babcock and Russell point out that there are two kinds of losses in the silo: (1), the unavoidable losses which are due to the formation of water, carbon dioxide, and volatile organic acids which are produced as a result of the intra-molecular respiratory process of the ensiled tissue. As these changes are prolonged in the more active and immature tissues in comparison with the more mature, the losses in the first case are greater. (2), The avoidable losses which are due mainly
\end{abstract}

1. Wis. Exp. Sta. Bul. 19, pp. 19. 2. Ark. Exp. Sta. Rpt. 1890, pp. 5. 3. Penn. State Col. Rpt. 1890, pp. 67. 4. Wis. Exp. Sta. Rpt. 1900, pp. 123-141. 
to the decomposition of organic matter induced by the development of bacteria and moulds, the growth of which is greatly facilitated by the admission of air, as a result of imperfect construction of the silo. 'Hing's results substantiates Russell and Babcock's contentions. He weighed the forage as put in the silos and silage when taken out for three years. That lost by moulding was weighed separate from the good silage. Samples were taken from each load of corn as it was cut and put in the silo, and the average of all these samples was used to represent the contents of that silo. One or more tons of silage was taken from the silo at a time, and samples of from 50 to 80 pounds taken from each of these lots. About 200 grams was taken from this sample for analysis, and 30 pounds weighed into a wire basket for the determination of dry matter.

The first year, 1893, there was put into the silo 63.37 tons of corn, and there was removed from it 57.2 tons of thoroughly good, bright green silage, making a loss of $10.16 \%$. When the spoiled was included in this there was a loss of only $7.35 \%$. The loss in ary matter was $8.10 \%$ in the first case, but with the mouldy silage included this was reduced to $4.95 \%$. The results obtained the next year in silo with 67.85 tons were practically

1. Wis. Exp. Sta. Rpt. 1895, pp. 373-378. 
the same s. those for 1893, with the exception of a little greater loss in dry matter. Thus lir. King's results show both the avoidable and unavoidable losses in the silo.

1 King again in 1900 conducted an experiment with silage in small glass jars to determine the effect of air on the loss in weight of silage. In both tests that he run, there was a greater loss in the jars containing a large amount of air than in those with a very small amount, or none; the percentages being $3.68 \%$ and 1.27\% respectively. In another experiment he siloed in pint mason fruit jars, field peas, just passed the blooming stage, cowpeas with young peas, first cutting of alfalfa, oats just beginning to head, and corn just coming into roasting ears. In 108 days the alfalfa silage lost $3.01 \%$, field pea silage lost $2.40 \%$, cowpea silage lost. $91 \%$, oat silage lost $2.3 \%$ and the corn silage lost $4.93 \%$ of dry matter.

An experiment is reported by the Geneva, New York, Experiment station, which consisted in burying sacks of silage in a silo at different depths at the time of filling. It was found that with thirteen different sacks there was an average loss of $12.6 \%$ ary matter, $26.6 \%$ sugar and starch, $15.1 \%$ of nitrogen-free

1. Wis. Exp. Sta. Rpt. 1900, pp. 189-196.

2. Wis. Exp. Sta. Rpt. 1901, pp. 200-209.

3. N. Y. State Exp. Sta. Ilth. Ann. Rpt. pp. 162. 
extract, $9.8 \%$ of crude fiber, $18.5 \%$ of albuminoids, - $4 \%$ of ash, and $3.9 \%$ of water. There was an apparent increase of $45.4 \%$ of crude fat, which was doubtless due to the fact that in the fermentation in the silo a larger percentage is rendered soluable in ether and this ether extract was termed crude fat in this experiment. It is also pointed out that the greatest loss in the silo is in the ary matter as claimed by ${ }^{1}$ cooke. Cooke siloed corn in the glazed stage, using a small tank three feet high and about two feet in diameter, and found a loss of $2.67 \%$ of water and $14.67 \%$ of dry matter. The loss in dry matter fell almost entirely on the nitrogen-free extract. The acid was not determined. Cooke does not claim the above results are typical of all silos and sights as an example some tests made the year previous which showed the amount of water lost was from six to seven times as much as the dry matter. In each of the cases of the previous year the contents had heated considerably, while in the case of the small tank almost no heat was developed. It is natural to suppose that high temperature tends to drive off a large proportional amount of water. a The Kansas Experinent station in siloing different crops for a period of six years shows an average loss of $12.3 \%$ by weight in silage. They filled

1. Vt. Exp. Sta. Rpt. 1889, pp. 96.

2. Kan. Exp. Sta., Bul. 48, pp. 33-40. 
three silos of varying capacity from 33 tons in the case of the smallest to about 100 tons in the largest. These silos were filled in the usual manner each year with either corn, sorghum, or Kafiir corn. The corn was cut as near the hard dough stage as possible and the sorghum was mature. Uniting and averaging the results for the six year period, they found that $77.2 \%$ of the total was good feed, $10.5 \%$ was rotten, and $12.3 \%$ lost. 1 Kalngin and Parashchuck point out with an experiment in siloing red clover, cabbage, and fodder carrots, that close packing of the material in the silo aided their preservation, the structure of the fodder being maintained and an agreeable odor being produced. The loss of organic substance was reduced, except that the decomposition of proteids was considerably increased. Close packing also caused an increase in the formation of free organic acids. Loose packing on the other hand was not favorable, the fodder becoming covered with moulds and acquiring a disagreeable odor and the loss of organic substance increasing except in the case of proteids. They also showed that the addition of carbon bisulphid to the silo greatly diminished the loss of all organic nutritive substances, especially when the fodder was loosely packed, and it arrested in a considerable

1. Zap. Novo-Alexandri Inst. Selsk. Khoz. i Lyesov., 1899, pp. 39. 
measure the development of free organic acids. 1

Kellner points out that silage made from green maize, when taken out of the silo, or pit, at the end of 120 days had 10 st $17.5 \%$ of organic matter, $22.3 \%$ of crude protein, $41.7 \%$ of pure protein, $21.1 \%$ crude fiber, and $17.5 \%$ of nitrogen-free extract. Beet tops and leaves after being in a pit silo for 140 days showed a loss of $49 \%$ of dry matter, $63 \%$ of cruade protein, $74 \%$ of pure protein, $33 \%$ crude fiber, $43 \%$ nitrogen-free extract and $67 \%$ of mineral substances. According to other observations made by Kellner, sliced beet roots ensiloed for seven months in a wooden lined pit silo lost $22 \%$ of organic and in an unwalled silo there was $35 \%$ loss. Potatoes lost in sixteen months $19-36 \%$, mangels $32 \%$, and beet leaves $31 \%$, the loss increasing with the length of storage period. However, it was shown by $\mathrm{Mr}$. Kellner in other experiments that the great loss in the above was greatly reduced when a water-tight silo was in the place of the very poorly constructed ones used in the first experiment. 2

Tangi and Weiser demonstrated that when green alfalfa was siloed for eight months it lost $33.3 \%$ in total weight. The outer layers of silage were more or less mouldy and in some cases it was charred.

1. Landw. Vers. Stat. pp. 105-114.

2. Landw. Vers. Ste.t., 74 (1911), No. 3-5, pp. 263-342. 
The results before and after siloing are shown in the following table for both green alfalfa and corn stover:

\begin{tabular}{|c|c|c|c|c|c|c|c|c|}
\hline Añalysis & $\begin{array}{l}\vdots \\
\vdots \\
\vdots \\
\mathrm{H}_{2} \mathrm{O} \\
{ }^{2}\end{array}$ & $\begin{array}{c}\text { : Percent } \\
\frac{\text { Protein }}{\vdots} \\
\vdots: \\
\vdots: \text { Crude: Pure } \\
\vdots\end{array}$ & $\begin{array}{l}: \\
: \\
: F a\end{array}$ & $\begin{array}{l}: \\
:\end{array}$ & $\begin{array}{l} \\
:\end{array}$ & $\begin{array}{l}\text { :Energy } \\
\text { :Value } \\
\text { :Cal.in } \\
: 100 \mathrm{Gr}^{\prime} \mathrm{s} \\
:\end{array}$ & $\begin{array}{l} \\
\vdots \\
\vdots \\
\vdots \\
:\end{array}$ & $\begin{array}{c}\% \\
\text { Ash }\end{array}$ \\
\hline $\begin{array}{l}\text { Alfalfa When } \\
\text { Put in silo }\end{array}$ & $: 13$ & $:: \vdots:=0$ & $: 3 \cdot 3$ & $: 20.6$ & $: 42.67$ & $\vdots 390.1$ & $\vdots$ & \\
\hline $\begin{array}{l}\text { Alfalfa When } \\
\text { Taken } \\
\text { Out of silo }\end{array}$ & $:$ & $\begin{array}{ll}: & : \\
: & : \\
: 10.62: & \\
: & : 2\end{array}$ & $: 1.63$ & $: 10 \cdot 31$ & $:=124 \cdot 98$ & $: 235.6$ & $\begin{array}{l}: \\
\vdots \\
\vdots\end{array}$ & \\
\hline $\begin{array}{l}\text { Corn stuver } \\
\text { When } \\
\text { Put in Silo }\end{array}$ & $\begin{array}{l} \\
\vdots \\
: 15 \\
:\end{array}$ & 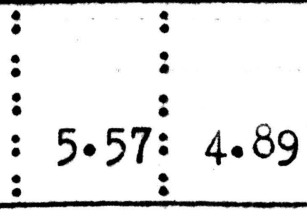 & $\begin{array}{l}: \\
: \\
: 1 \cdot 4 \\
:\end{array}$ & $\begin{array}{l}: \\
: \\
: 27 \cdot 53 \\
:\end{array}$ & $\begin{array}{l}: \\
: \\
: 44 \cdot 25 \\
:\end{array}$ & $\begin{array}{l}\vdots \\
\vdots \\
\vdots \\
\end{array}$ & $\begin{array}{l}: \\
\vdots \\
\vdots\end{array}$ & 6.24 \\
\hline $\begin{array}{l}\text { Corn stover } \\
\text { When Taken } \\
\text { Out of silo. }\end{array}$ & $\begin{array}{l}: \\
\vdots \\
: 65\end{array}$ & $\begin{array}{cc}: & : \\
: & \vdots \\
: & : \\
: & 2.51: 1.48\end{array}$ & $:$ & $:$ & $\begin{array}{l}: \\
: \\
: 17.1\end{array}$ & $\vdots$ & : & 2.8 \\
\hline
\end{tabular}


In metabolism experiments with wethers showed a loss in digestibility of all constituents of the alfalfa silage as seen in the following table:

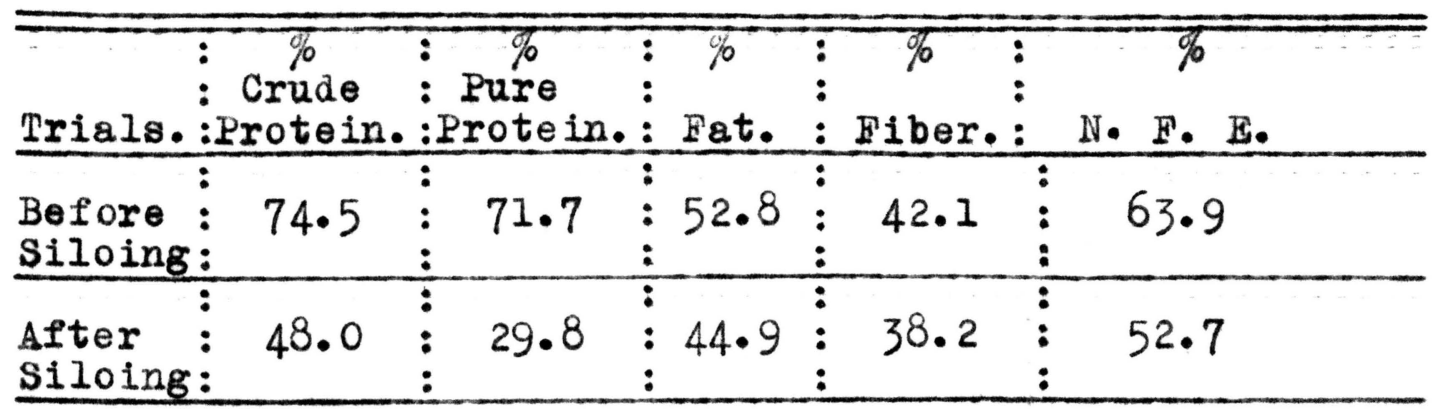

The stover silage was made in an iron-concrete silo. As noted in the first table there was not as great $10 \mathrm{~s}$ in nutriment as in the case of the alfalfa, and this loss was off-set by the increased palatability of the stover.

1 Smith reports an average loss of $8.32 \%$ in total weight for four silos. The greatest loss was noted in silage made from immature corn, the los decreasing with the maturity of the corn. Morse claims that this loss is due to the immature corn having a larger amount of sugar than the more mature corn. He shows that the greatest loss comes in the sugar of the plant, and in the case of mature corn this sugar has been converted into starch which is changed but

1. Mich. Exp. Sta. Bul. 191, pp. 165.

2. N. H. Exp. Sta. Bul. 92, pp. 59-62. 
very little in the silo. Smith's figure of $8.32 \% 10$ s includes the loss from mouldy silage. Cooke reports a loss of only $3 \%$ but he does not include the loss from mould. Penny, shows in his results a loss of $6.0 \%$ which agrees quite closely with the above results. He claims that the greatest loss is in the sugar and is brought about more rapidly with a high temperature. On comparing the composition of silage with that of the maize from which it was formed, Russell of the Rothamstead Experiment station, England, found that the fiber was practically unaltered in amount. He confirmed his observations by microscopical examinations of sections of maize and of the silage afterwards produced. He found that the epidermal cells had undergone no change in the silo beyond a certain amount of shirnkage; even the stomata were intact. Similarly the vascular bundles were intact. He showed that nitrogen-free extract suffered most, and a direct test showed that the sugar disappeared almost entirely. The less resistant celluose showed a decrease in amount. The protein suffered considerably, though not as much as the nirtogenfree extract. His table is as follows:

1.Colo. Exp. Sta. Bul. 57, (1902) pp. 15.

2. Del. Sta. Rpt. 1903, pp. 40-41.

3. Jour. Agri. sci. 2(ig08), pp. 387. 
Mean Ioss In The Silo.

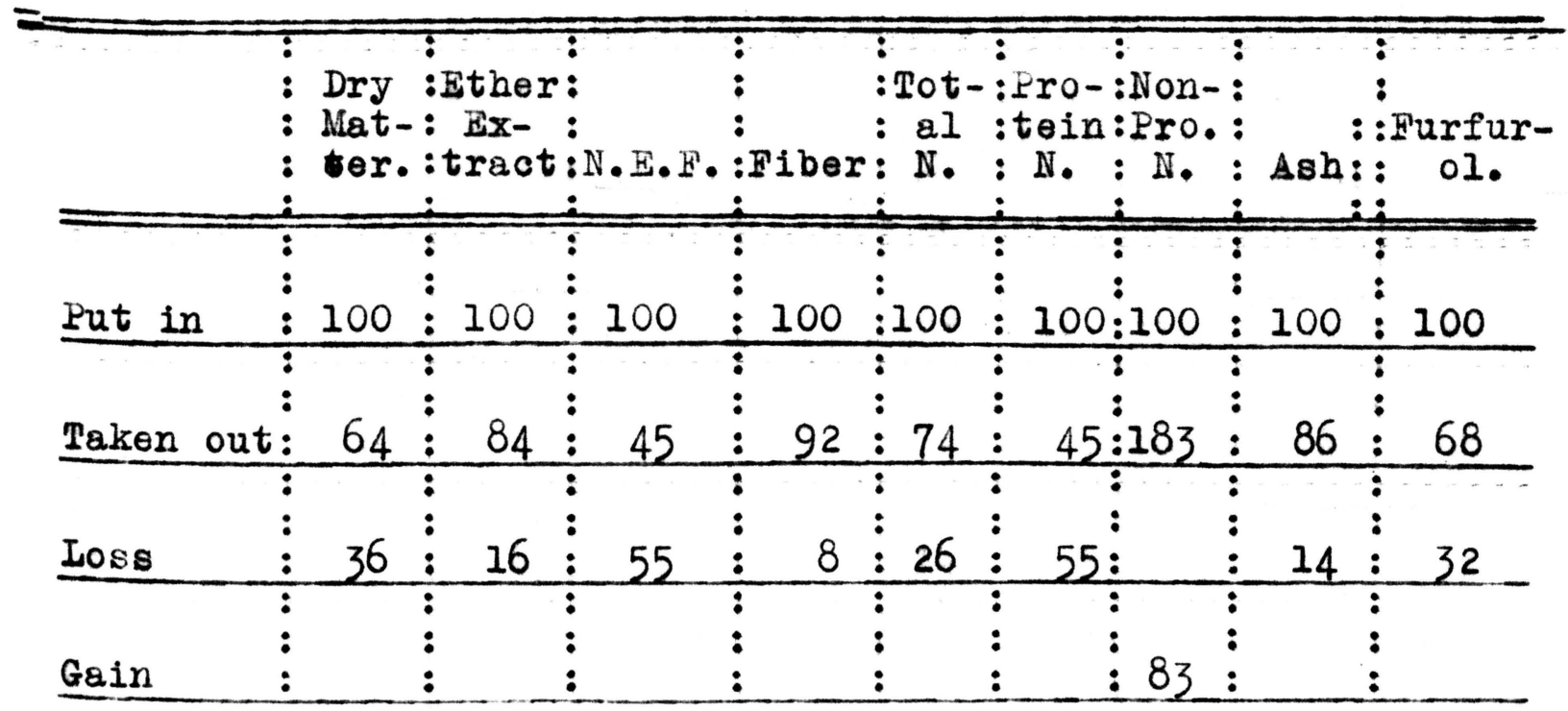

1

Magruder reports a loss of from. 31 to $5.86 \%$

in green corn silage, and a loss of from $2.49 \%$ to $6.66 \%$ in silage made from shock corn. Oshel reports a loss of $3.37 \%$ by weight in silage made from peas and oats, $2.46 \%$ in that made from corn, an average of $4.48 \%$ in that made from soy beans, $4.83 \%$ in partially dried corn silage, and 7. $5 \%$ in silage made from corn fodder.

The figures reported by Magruder and Oshel do not include the loss from mouldy silage.

1. Thesis, "Silos \& Silage", for the degree of A. M. Univ., Mo., 1914.

2. Thesis, "Silage Investigations", for the degree of A.M. Univ., Mo., 1915. 
IEGUMES FOR SILAGE.

Heretofore the legume crops have not been considered very good for silage purposes, but recently it has been shown that there are conditions under which they may prove satisfactory. At the present time there is much experimental work being done with these crops for silage purposes.

Alfalfa:- At the Colorado Experiment station some tests were made on a small scale to show what losses might be expected in making silage of alfalfa. One test was made with the alfalfa placed in the silo as cut in the field, and the other with the alfalfa cut to quarter inch pieces. The whole alfalfa showed a spoiled layer three inches thick on top and an inch layer around the sides nearly all the way down. The silage of the bottom and middle was excellent and was gredily eaten by the cows and calves. Its loss in total weight was $10.7 \%$, but its loss in feeding value was probably a little larger. on the day after filling the silo with the cut alfalfa it was covered with two thickness of building paper and one of boards, and weighted with stones to about fifty-five pounds per square foot. When covered

1. Colo. Exp. Sta. Bul. 57, pp. 10. 
the silage was hotter than the hand could bear. Two days later the temperature had fallen to $83^{\circ} \mathrm{F}$. and in two days more it had fallen to that of the air. The silage shrunk and settled a great doal. When put in, it contained $33.0 \%$ of dry matter. On opening, the silo showed two inches of spoiled silage on top and half an inch on the sides. The spoiled silage was $7.3 \%$ of the total weight. The loss in dry matter was approximately $10 \%$

At the Kansas Experiment station alfalfa has 1 been ensiled fairly successfully. Professor Reed in writing on this subject says that alfalfa makes good silage but the silage will not keep but a few months in a good condition. Professor stone of the Cornell University reports practically the same results as the Kansas Station. He obtained satisfactory results from siloing one hundred tons of alfalfa. The silage was fed out during the summer and was eaten fairly well. Some that remained in the silo and was covered with corn in September came out the following spring in a less satisfactory condition. The practice was not considered sufficiently successful to warrant its continuance. The results of various experiments indicated good returns from alfalfa silage if it is fed within a few months.

2. Correspondence. 
Digestion experiments with sheep on alfalfa hay and alfalfa silage were carried on by Professor True of 1

the Nevada Experiment station to determine their relative values. The hay was from the first cutting of alfalfa and the silage from the second cutting. The digestability of the two feeds is shown in the following table:

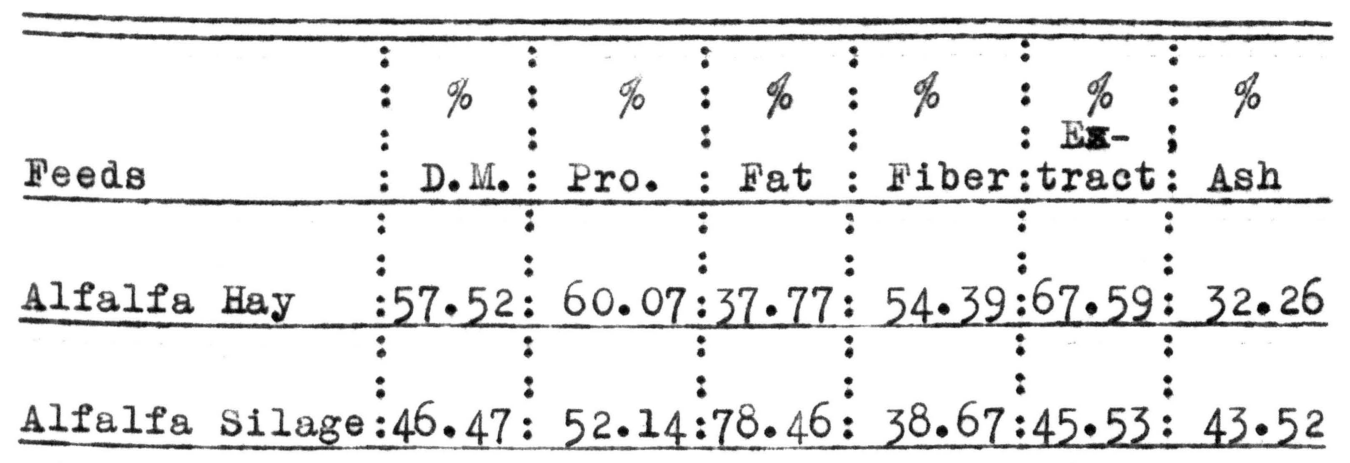

On comparing the two it can be seen that the alfalfa hay is more digestable. Magruder buried two sacks of alfalfa in a large silo. The alfalfa was cut the usual length for silage with a silage cutter To one of the sacks he added sugar by sprinkling over the alfalfa. Both sacks when removed from the silo were in excellent condition, the silage having the appearance

1. Nevada Exp. Sta., Bul. 72, pp. 37-40.

2. Thesis, "Silos \& Silage", for the degree of A. M., Univ. Mo., 1914 . 
of green alfalfa. The sugar had no effect on the amount of acid developed as it was at first supposed. 1

oshel put the second cutting of alfalfa, the most of it being in bloom, into a small experimental silo. The silage made therefrom had $2.05 \%$ of acid and was in excellent condition when taken out of the silo, although it seemed quite dry. It seemed to mould vary easily, as there was considerably more mouldy silage on top than there would have been with orainary silage crops. Some experiments at Piacenza, with the second cutting of alfalfa showed that this crop could be siloed to good advantage. The silage to which lactic acid ferment was added gave better results than that with no culture. Four small silos (one ton each) were filled at the 3 Nebraska station in 1914, one with alfalfa and three with alfalfa and cane mixed in different proportions Eleven months after filling, the silos were opened and the silage in all, except one containing alfalfa alone, was in perfect condition. It was found that a mixture composed of two parts of alfalfa and one of cane made silage of an excellent quality, it having $1.3 \%$ acid and $62.13 \%$ of moisture. Clover:- ${ }^{4}$ clark demonstrated that the second crop of

1. Thesis, "Silage Investigations", for the degree of A. M., Univ. Mo., 1915.

2. Milch Zentr., 43, pp. 15.

3. Neb. Exp. Sta. Press Bu. 46.

4. Mont. Exp. Sta., Bul. 94. 
of clover made into silage during September and October after being frozen, kept well until May and June the following year, but becones dark in color, strong in odor, and was not relished by dairy cows after the weather became warm, although they relished it and had a keen appetite for it during the winter months. As an of three experiments of two periods each, he pointed out that the clover silage was more economical as a feed for dairy cattle. On clover hay the cost of producing one hundred pounds of milk was 73.9 cents, and of one pound of butter fat 17.9 cents, while on clover silage the cost of producing one hundred pounds of milk was 73.4 cents, and of one pound of butter fat 17.8 cents. However, in milk production 2.33 pounds of clover silage was required to equal one pound of clover hay. The value of clover silage according to the experiments reported, ranges from $\$ 2.36$ to $\$ 2.76$ per ton. With experiments at the Oregon Experiment Station, it was clearly demonstrated that clover cut at the proper stage of ripeness and put into a properly constructed silo would make good silage. 'Short points out that clover cut on a bright day and allowed to lay in the sunlight for four or five hours before putting in the sila

1. Ore. Exp. Sta. Bul. 67, pp. 105.

2. Wis. Exp. Sta. Bul. 67, pp. 27. 
made excellent silage with very little acid content. 1

Whitcombe's results agree quite closely with short's. He points out that as good results were obtained with clover when siloed wi thout being cut as there were when it was run through a cutter. 2

Cowpeas:- Oshel did not obtain good results in siloing cowpeas. The hay was necessarily cut very immature. The silage developed only . $4 \%$ of acid, was very wet, and had a somewhat disagreeable odor and taste. The silage in the bottom had an excess of moisture. Regardiess of the disagreeable odor and taste, the cows seemed to relish it very much. ' 3 the other hand, Professor stone says he has had good results in siloing cowpea hay, it producing excellent silage. 4 Soule and Fain tried growing cowpeas with a crop of corn and sorghum for the silo. They thought that the cowpeas would raise the protein in this mixture so it would make nearly a balanced ration. They found that the cowpeas greatly improved the quality of silage, but did not grow "renk" enough to raise the protein in the mixture to any appreciably extent.

1. Ore. Exp. sta. Rpt. 1904, pp. 28-29.

2. Thesis, "Silage Investigations", for the degree of A. M., Univ. Mo., 1915.

3. Personal correspondence.

4. Tenn. Sta. Bul. Vol. 17, No. 1, pp. 17-19. 


\section{1}

The Illinois Experinent station reports the

digestibility of cowpea silage to be as follows: dry matter, 60\%, ash, 32\%, protein, 49\%, fat, $82 \%$, fiber, $63 \%$, and carbohydrate extract, $68 \%$.

Soybeans:- Soule and Fain in some trials at the Tennessee Experiment station with soybeans alone as silage, obtained good results. They claim, however, that this crop is too expensive for silage purposes in comparison with its feeding value. Woods and Bartlett claim that soy bean plants alone do not make good silage, but make excellent silage when mixed with corn. They mixed corn and beans in the proportion of about fourteen parts of corm to nine parts of beans. The silage kept perfectly, and when fed out was nearly as green as when it was put in the silo. The animals ate it with great relish, and sheep preferred it to corn silage. They showed that eight tons of soybean fodder had about the same amount of protein as twelve tons of corn, in the milk stage, ready for the silo, but it had only a little more dry matter than eight tons of corn. 4 Haward reports a loss of $43 \%$ in a silo filled with a mixture of corn and soja beans. At the time of opening the silo there was only a loss of eight per cent

1. I11. Exp. Sta. Bul. 43, Dp. 190.

2. Tenn. Exp. Sta., Bul. Vंol. 17, No. 1, pp. 17-19.

3. Me. Exp. Sta. Bul. 106, pp. 118.

4. Md. Exp. Sta. Ann. Rpt. 1891, pp. 349. 
but upon exposure to the air the soja beans acquired a certain musty smell, and the cows refused to eat it. 1

The Hatch Experiment Station reports the digestibility of soybeans silage as follows: protein, 55\%, crude fiber, $43 \%$, nitrogen-free extract, $61 \%$, and ether extract $49 \%$.

SHOCK CORN SIIAGE.

2 Armsby and Caldwell of the Pennsylvania Station in a series of experiments in which they compared the method of putting corn in the silo with shocking it in the field, show that out of every hundred pounds of dry matter in the original orop, there was a loss of 10.75 pounds by fermentation in the silo (not including the loss by moulding), and 21 pounds by field curing. This seems to agree quite closely with an average from other stations in which they report a loss of 17.75 pounds in siloing and 21.3 pounds in field curing from every one hundred pounds. In the above experiment, the silage lost about two-fifths as much protein as the fodder, but over one-fourth of its albuminoids were converted into the less valuable albuminoids. The fodder lost more fiber and ash than the silage, and the losses of nitrogen-free extract were about in proportion to the

1. Mass. Hatch Exp. Sta. 9th. Ann. Rpt.pp.165

2. Penn. Exp. Sta. Rpt. 1889, pp. 113. 
losses of dry matter. In all cases, good results were obtained in siloing shock corn when water was added in the ration of $1: 1$.

In other experiments ${ }^{1}$ Armsby and Caldwell found. that the corn silage was very nearly as digestible as the fresh fodder. The shock corn was considerably less digestible than either the fresh fodder or the silage. 2 Woll of the Wisconsin Station, as the result of three year's investigations, reports an average loss of dry matter in shocked fodder corn of $20.33 \%$, and of protein $15.55 \%$. At the same time he found the losses in the silo with Indian corn of the same variety and in the same stage of growth to be $20.5 \%$ of dry matter and $20.6 \%$ crude protein. In $1890, \mathrm{Mr}$. Woll conducted another experiment along this line by cutting every other row of com in the field and putting it in the silo, the rest to be cut and shocked in the field. He used the weight of that put in the silo (129,014 pounds) as the weight of corn shocked in the field. In this experiment he reports a $10 \mathrm{ss}$ of $10.3 \%$ of dry matter and 12. $5 \%$ of protein during the siloing period. In the other half of the corn shocked and left in the field the greater portion of the winter, he found a loss of $28.3 \%$ of dry matter and $34.8 \%$ of protein. He claims this to be a better average than his results previously reported.

1. Penn. Exp. Sta. Rpt. 7890, pp. 444 : 1891, pp. 229. 
1 King of this station found that when corn fodder contained from $30 \%$ to $35 \%$ of dry matter when put in the silo, made as good silage as the less mature corn. He clearly demonstrated that the fodder should not contain more than $35 \%$ of ary matter when put in the silo, if so, water should be added to reduce it. Voorhees and Iane, experimenting with shock corn for silage obtained practically the same results as King. They found that when water was added in sufficient quantity to raise the moisture content of the fodder to $75 \%$ they got good results. They further demonstrated that when a large amount of water was required, that it could not be added in sufficient amount while the silo was being filled, but would have to be sprinkled over the surface from day to day after the filling was finished. The chemical analysis of this shocked corn before and after putting in the silo showed that a marked change took place during the time it was stacked in the field., which resulted in an increase in ether extract and fiber, and a decrease in protein, ash, and nitrogen-free extract. A comparison of the composition of the dry matter of the green forage and of the silage showed that the change in the proportion of fiber and nitrogen-free extract, though a slight increase was noted in the ether extract.

1. Wis. Exp. Sta. Bul. 59.

2. N. J. Exp. Sta. Bul. I22. 
In feeding these two feeds with the same kind

and amount of concentrates to milch cows, these men obtained considerably beiter results from the silage.

1 Kedzie, with corn fodder containing from $13 \%$ to

$30 \%$ of dry matter, made silage of a quality corresponding to the per cent of dry matter. Silage made from forage containing only $13 \%$ of dry matter made a silage with a very disagreeable odor and taste, and had a high acid content. The quality of the silage increased with the per cent of dry matter until the dry matter reached about $35 \%$. At this point the silage showed a tendency to mould very rapidly.

2

The Deleware Experiment station reports good results obtained by putting shocked corn in the silo in the proportion of .75 parts of water to one part of fodder. The fodder contained $53.3 \%$ of dry matter when it was taken from the shock. The fermentation taking place in this silage seemed to be as near those of green corn silage as possible. 3

Beach, of the Vermont station, reports similar results to those from the Deleware station. The fodder contained 60\% of dry matter when taken from the shock. Fnough water was added to bring it to $25 \%$ and the silage produced was excellent. He agrees with Voorhees and Iane, thet all of this water cannot be added at the time of filling.

1. Mich. Exp. Sta., Bul. 68, pp. 10.

2. Del. Exp. Sta. Rpt. 1903, pp. 38.

3. Vt. Exp. sta. Bul. 170 . 
1

Magruder found that when water was added to corn fodder in the ratio of $1: 1$, it produced excellent silage. 2

Oshel reports the same results. He further points out

that small cans filled with fodder, with water added in the proportion of $1: 1$ and kept at about $64^{\circ}$ F. for fortyone days produced no fermentation.

\section{SIIAGE FROM OTHER CROPS.}

3

Minkler, of the New Jersey Station, with some

trials with oats and Canada peas, concluded that when it

is impossible to store sufficient corn for summer use, oats and peas make a splendid silage and that it is more economical to ensile the oats and peas rather than cut green and feed daily as green forage.

Mr. H. O. Daniels of Midaleton, Connecticut, in relating his experience with siloing oats and alfalfa, says that until he discovered the fact that oats and alfalfa made excellent silage, he was losing a great profit from his dairy herd every year, but since he started to siloing his oats and alfalfa, he has changed the loss to profit. He says that he always obtained excellent results in siloing these two crops.

1. Thesis, "Silos \& Silage",for the degree of Amil, Univ.Ho.1914

2. Thesis, "Silage Investigations", for degree of A.M.,Univ. Mo. 1915.

3. N. J. Exp. sta. Rpt. 1911, pp. 51.

4. Mass. Bd. Agr. 1911, pp. 52 . 
1 The California Experiment station reports the dry matter in one hundred pounds of oat silage to be 28.0 pounds and the digestible nutrients in one hundred pounds to be 1.5 pounds of protein, 14.8 pounds of carbohydrates, and 9 pounds of fat. Rye:- Churchill, of the Oklahoma station, points out that the best quality silage can never be made from plants having a hollow stem; rye is therefore not good for this purpose. He claims that the yield of rye is too small to permit of its use profitably for silage. No reports could be found concerning experimental work with rye for silage. Sudan Grass:- Sudan grass is suited admirably for use as a silage crop, since it makes a large yield and is very palatable in the green state, as well as when cured for hay. Enormous jields are secured under irrigation, because the growth is so rapid and the recovery from cutting so prompt. A small area in the south where the rain-fall is adequate can be made to support a goodly number of animals by this method.

No trials of sudan grass as silage have as yet been carried out, but judging from its palatability and its sugar content, it would he excellent for this purpose, especially in mixtures with legumes. Its use for silage will no doubt be very limited, owing to the ease

1. Cal. Exp. Sta. Bul.732,pp. 8.

2. Okla. Exp. Sta. Circ. $34(1914)$ pp. 14. 
of making it into hay, and the fact that there is but little waste in feeding it.

1

The Oklahoma Experiment Station reports the analysis of sudan grass to be as follows: water $7.2 \%$, ash, $5.6 \%$, protein, $7.9 \%$, fiber, $31.56 \%$, nitrogen-free extract, $45 \%$ and fat, $2.25 \%$.

WEIGHT OF SIIAGE PER CUBIC FOOT.

\section{2}

Professor F. E. Emery mentions having filled several silos to a depth of fourteen feet where the mean weight was less than 26 pounàs per cubic foot. He cites another silo 31.5 feet deep, filled with King Philip corn, where the silage weighed in, averaged only 34 pounds per cubic foot, but which settled so as to average 41.8 pounds, supposing no loos to occurred. The New York Experiment Station reports, with two silos after being filled two days, averaged when full, 25.9 and 25.7 pounds per cubic food, but settled in two and one-half days so as to average 32 pounds. ${ }^{4}$ Two silos filled at the Kansas station

1. Okla. Exp. Sta. Bul. 103, pp. 12.

2. N.C. Exp. Sta. But. 80.

3. N. Y. Exp. Sta. 7th. Ann. Rpt. pp. 324-331.

4. Kan. Exp. Sta. Rpt. 1889, pp. 58. 
so as to be 20 fet deep, two days after filling had an average weight of 34 pounds per cubic foot. A round silo 1 at Whitewater, Wisconsin, 22.75 feet in diameter and 34 feet deep when filled, settled to 27 feet and weighed on an average of 44.6 pounds per cubic foot. The silage in this case was made of part flint and part dent corn, both being well glazed, and a little dry when put in 2

the silo. The Missouri station reports a silo $16 \times 22$ feet and 16 feet deep to hold eighty-five tons of silage, thus making the mean weight per cubic foot 30 pounds. In a silo $15 \times 13.83$ feet and 22 feet deep, filled with clover, ${ }^{3}$ Lawes and Gilbert report a mean weight per cubic foot of 53.6 pounds. 4

King of the Wisconsin station, assuming the mean weight of well glazed corn silage, cut in slowly, to a depth of twenty-seven feet, to be 42 pounds per cubic foot, the upper thirteen feet to averige 26 pounds and 45 pounds as the weight of a cubic foot thirteen feet below the surface. He, further assuming that below this thirteen foot level the weight per cubic foot increased uniformly until 63 pounds was reached, which was the maximum weight. From this he computed the weight of a cubic foot of silage at different depths in the silo. As shown in his table, he obtained the maximum weight

1. Wis. Exp. Sta. 8th. Ann. Rpt. pp.242.

2. Mo. $\operatorname{Exp}$. Sta. Bul. 7, pp. 4.

3. Rothomstead Memoirs Vol. 4, pp. 9-11.

4. Wis. Exp. Sta. Rpt. 1891. 
at a depth of twenty-three feet in the silage and below this depth he considered the weight uniform for succeeding depths. He further points out that from the facts in the table, that the storage capacity of silos increase more rapidly than the depth until the weight has become great enough to compress the silage to its maximum limits, and that beyond this the capacity increases directly as the depth. 1 King afterwards published a table in which he has calculated the weight of a cubic foot of silage at different depths, begirring with a depth of one foot and going to a depth of thirty-six feet. This table was computed for well matured corn silage, and also includes the mean weight at different depths two days after filling.

1. Wis. Exp. Sta. Rpt. 1893, pp. 207. 


\section{WEIGHT OF SILAGE AT DIFPEREIT DEPTHS.*}

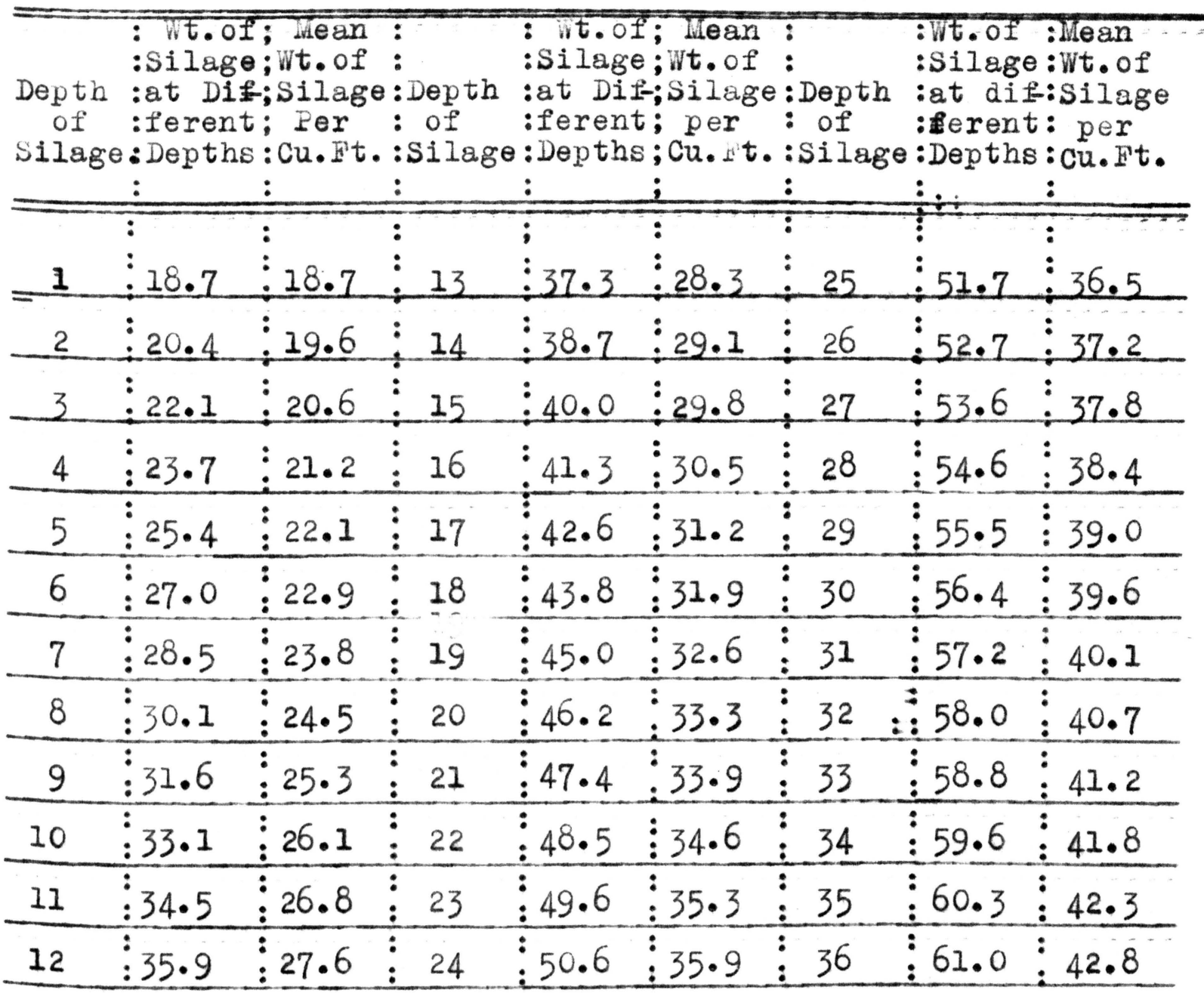

*King's last table. 
1

Professor shelton of the Kansas Experiment Station, by the means of a dynamometer, took the lateral pressure of silage at different depths while the silo vas being filled. He reported the pressure as ranging from fifteen pounds per square foot at a depth of three feet in the silo, to fifty-six pounds at a depth of twenty feet, which proved to be the maximum pressure. King reported the results of an experiment to determine the lateral pressure in the silo by means of a pressure plate. In general the figures reported are much larger than those reported from Kansas. King claims that the pressure after a depth of three feet is reached, increases at a rate of nearly eleven pounds for each foot of depth, untill settling is complete. To show that there is no lateral pressure after settling is complete, $\mathrm{Mr}^{3}$ King sights the burning of two silos in which settling was complete. The silage stood in the natural form of the silo after the walls were burned. ${ }^{4}$ Cooke of the Colorado Station divided an experimental silo into three layers with boards to separate the layers, and rods extending from the boards to the surface so that the amount of settling could be recorded. When the weights and top were removed it was noticed in a short time that the

1. Kas. Exp. Sta. Rpt. 1888, pp. 98 .

2. Wis. Exp. Sta. Rpt. 1891, pp. 249.

3. Wis. Exp. Sta. Rpt. 1894. pp. 289.

4. Colo. Exp. Sta. Bul. 57, pp. 15-17. 
top layer had expanded, or raised two and one-half inches. This was the expansion of the whole mass. The first and third layers expanded one inch each, and the midale, onehalf inch.

The following formula suggested by $\mathrm{Mr}$. I. I. J. Mentsch of San Francisco, for round concrete grain elevators, which are similar to silos, may be use to get the pressure per square foot in a silo. Mr. Iinting says that with little allowance, this formula can be applied to silos when you have the angle of repose, which is larger than grain. Formula:-"Assume the weight of grain equals 50 pounds per cubic foot, and the angle of repose equals $29^{\circ}$. Then by common theory of earth pressure, the pressure per lineal foot on a wall h feet high equals $7.7 \mathrm{~h}$, and the pressure per square foot at $h$ below the surface equals $15 \cdot 4 \mathrm{~h}$. This pressure in a bin of the diameter $\mathbf{s}$ in feet increases. However, only until h equals s cot. 29 equals 1.8s. Below this depth the friction against the sides equals the additional weight of the grain, and no matter how deep the bin, the pressure never exceeds 15.4 times 1.8 s equals 27.75 s, a fact fully demonstracted by practical experience." 2 Nagruder points thet the weight per cubio

1. Correspondence.

2. Thesis, "Silos \& Silage", for the degree of A. M. , Univ. Mo., 1914. 
foot of silage varies with the amount of moisture and the amount of grain. ' Oshel showed that the silage reached a limit of compressability at about nine to twelve feet, and below this point the increased pressure did not force out any more air. The weights pe $r$ cubic foot in different silos showed a great variation and the author concludes that the weights undoubtedly are affected by other factors other than the amount of water present.

$$
\text { MOULD IN SILAGE. }
$$

\section{2} During 1909 Buchanan made an examination of moulds occuring on silage. On cultures he isolated a number of moulds, among them several species of Penicillium, Aspirgillus, Mucor, and in one instance, Monascus. In the sample of silage used, the Monascus was practically the only mould found, which was carefully studied.

Several species of Monascus have been described, but the specimen studied in the above test seemed to correspond in all essential characters with M. purpureus. The author thinks that this is the typical fungus present in mouldy silage which is reported to have killed horses, but its pathological properties have not as yet been determined.

1. Thesis, "Silage Investigations", for the degree of A. M., Univ. Mo., 1915.

2. Mycologia, 2(1910) No. 3, pp. 99-108. 
Professor S. A. Ivanov points out that when some of the moulds conmon in silage are grown on different cultures, produce varied results. In one series of experiments, Professor Ivanov grew Penicillium glaucum and an unknown brown mould on flour obtained from Hungarian and zhelanni oats. When the mould was grown on the Hungarian oats, which had a low nitrogen content, nitrogen was assimulated from the air. In the moulding of Zhelanni oats, with a high nitrogen content, a decrease was noted in the total nitrogen. In general, the total nitrogen of the albuminoid substance decreased during the period of molding. 
EXPERIMENTAI METHODS.

Description of Silos Used:- The silos used in this experiment were as follows:

$$
\begin{aligned}
& \text { North concrete silo. } \\
& \text { South concrete silo. } \\
& \text { Six experimental silos. }
\end{aligned}
$$

The North and South concrete silos are situated at the dairy barn on the University farm. They are of the monolithic type, thirty-three feet high and sixteen feet in diameter, with concrete floors and set five feet in the ground.

The North concrete silo was filled September 22 to 24 , with corn in the dent stage. It was cut $\frac{3}{4}$ inch and well tramped into the silo. On september 23 and 24 water was added to the silage by running a small stream into the blower while the corn was being cut. Feeding was begun from this silo a short time after filling was complete.

The South concrete silo was filled september 26 to 29, with corn, the most of which had not passed the glaze stage. The corn was cut $\frac{3}{4}$ inch and well tramped into the silo. No water was added. After filling was complete, the surface was covered with tarred paper, 
then a layer of cowpeas cut fine was put on top of this paper.

Six circular water tanks, six feet high and three feet in diameter, and made of two-inch cypress were used as experimental silos. These silos are provided with tops of a size to fit tightly, but still to settle with the silage. The ex erimental silos were placed in the loft of the dairy barn for protection from the cold. They are designated as experimental silos No. 1, No. 2, etc.

Each time an experimental silo was filled a wire screen which would fit loosely in the silo was placed so that one or more feet of silage was above the screen when filling was completed. The weights of the amount of silage both below and above this screen were taken when put in and again when removed. The object in using this screen was to make it possible to distinguish between the loss of nutrients due to the fermentation of the silage and the loss on top that occurs from exposure to the air.

Taking Samples:- As the material was being weighed into the silo, a sample of about fifty grams was taken from each tub in which the silage was weighed and placed 
in a container which was taken to the laboratory. This composite sample was thoroughly mixed and one portion was taken for moisture determination and chemical analysis. The other portion was again mixed and a sample taken and preserved for sugar determination. As the silos were being emptied the same plan of taking samples was followed, except the second sample taken was used for an acidity test, which was run immediately.

Moisture Determination:- A sub sample taken as described above was weighed into a wire basket and placed in an electric drying oven, and dried until it was certain that the moisture content was the same, or below, that of the atmosphere. It was removed from the oven, weighed and placed in a mouse tight case until its weight was constant. This last weight was taken as the air dry weight of the sample. The samples were then preserved in half gallon fruit jars for chemical analysis. Acidity Test:- The sub samples for the acidity test were taken as described above, and the test made immediately. Each sample was run through a small meat cutter to chop the silage up fine, and then thoroughly mixed and a one hundred gram portion taken for the acidity test. This portion was washed with five hundred c.c. of distilled water and the washings titrated against a standard 
alkali until the last washing titrated the same as the blank which had been run on the distilled water. Five washings were usually required; twenty four hours or longer intervening between washings. Each washing was decanted into a suction filter, and the filtrate made up to $500 \mathrm{c.c}$. A $10 \mathrm{c.c}$. portion was taken and diluted with 100 c. c. of distilled water and titrated immediately. An average molecular weight of 80 was used for the mixture of acids in making the calculations.

Chemical Analysis:- All of the chemical analyses were made by the department of Agriculture Chemistry of the University, under the direction of Dr. P. F. Trowbridge. The methods used were those adopted by the American Association of Official Agricultural Chemists, for feed stuff analysis, with some slight modifications. Sugar Determination:-The determination of sugar was also made by the department of Agricultural Chemistry. The gravimetric method for invert sugars, using soxhlet's modification of Fehling's solution, was used for this determination.

Method of Taking Weights:- The weight of silage per cubic foot at different depths in the silo was taken by means of an apparatus devised by Reed of the Kansas 
Experiment Station. Whis is an iron frame which can be driven into the silage to enclose a cubic foot. This frame is a foot square on the outside and eighteen inches high. The upper six inches of the frame are braced for strength and to this upper part sharp pointed rods are welded, one on each corner and one in the midale of each side. The silage was cut around the outside of the frame with a hay knife and taken out of the frame to a depth of one foot and weighed for the weight of a cubic foot at that depth. The weights were taken as the silage was fed out. 


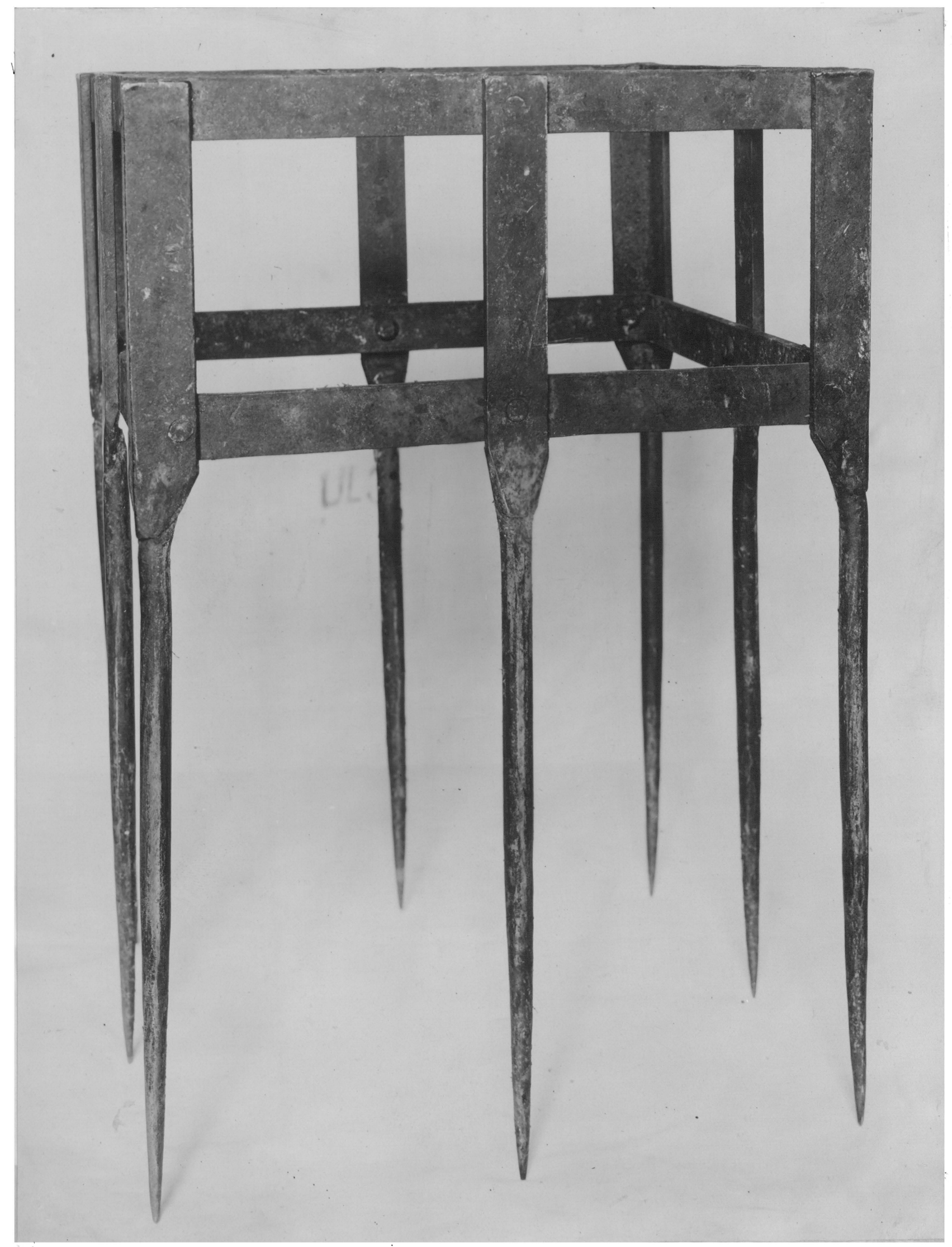

PIATE I.

"Kansas Apparatus" 
FACTORS INFLUANCING ACIDITY.

\section{Object.}

The object of this experiment was to determine:

1. The relation of the sugar content of the forage when cut to the acidity of the silage produced.

2. The amount of acid normally developed in different kinds of silage.

3. The relation between the moisture and acidity of the silage.

4. The effect of mould upon the acidity.

\section{Plan of Experiment.}

The silos used in this experiment were the North Concrete Silo, the south Concrete silo and six experimental silos.

(1). Relation of Sugar to Acidity:- Sugar determinations were made of samples taken from near the wall and near the center of the South Concrete silo at the time of filling. Acidity tests were made of samples from the same place when the silo was emptied.

Com in nearly all stages, from the milk stage in August to the hard dent stage in october was put into experimental silos. Sugar determination was made on a sample of corn from each silo at filling time, and an acid test was made on all silage when the silos were emptied. 
(2) Kind of Silage:- Moisture and acidity tests were made of green corm silage, shock corn silage, alfalfa silage, pea and oat silage, and sudan grass silage. Sugar determination was also made of the green corn and shock corn before it was put into the silo.

(3) Relation between Moisture and Acidity:The data on this factor is considered in other parts of this experiment. However, it will be taken up under a separate heading in the discussion of data.

(4) Effect of Mould on Acidity:- Three samples of 500 grams each were taken from the North Concrete Si10.

Sample No. 1, was tested immediately for acid. Sample No. 2, was set in a mouse-tight case at about $80^{\circ} \mathrm{F}$. and allowed to mold for three days, and then testod for acid.

Sample No. 3, was set under the same conditions as No. 2 and allowed to mold for six days and then the acid determined.

\section{DISCUSSION OF DATA.}

Relation of Sugar to Acidity:- Whon this experiment was begun it was thought that the amount of acid in silage is in direct proportion to the amount of sugar in the forage when cut. It was supposed that the maturity of the corn and the proportion of the grain 
to fodder had some effect on the amount of sugar in the forage and consequently the amount of acid in the silage. Table 1 gives data on corn forage as put into the silo and on the silage as taken out.

Table 1.

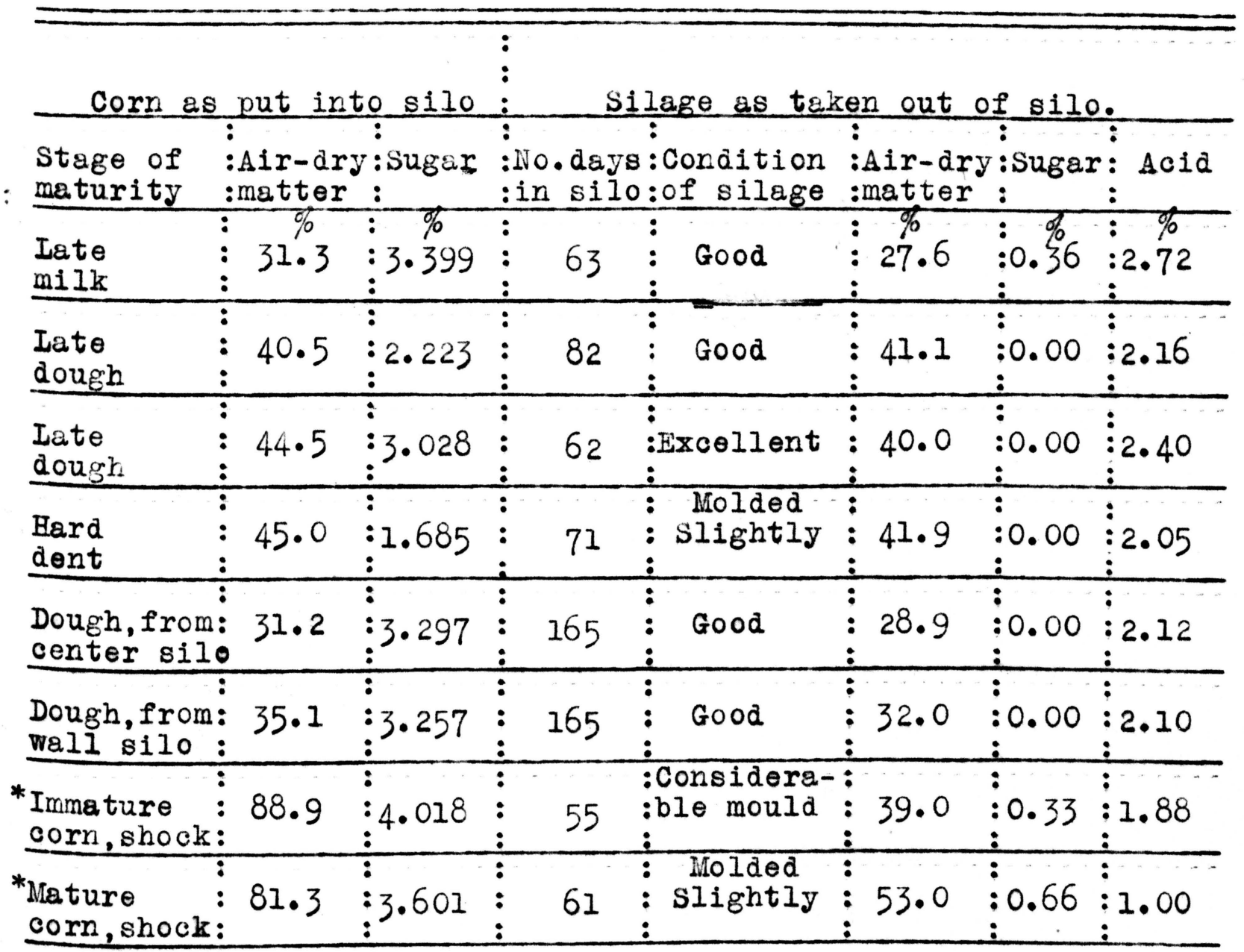

*Water was added to this corn in the ratio $1: 1$ when the silos were being filled.

In the investigations of silage up to the present time, not so much attention has been given to the sugar con- 
tent of the forage from which silage is made. According to many chemical tests the sugar in corn is mostly dextrose, the most easily fermented sugar. The sugar in corn averages from three to four per cent. as shown in Table 1. Previous investigators along this line claim that all of the sugar in the forage is converted into acid in the silo during the fermentation process, either by bacteria or by yeasts. They claim further that the per cent. of acid in silage is almost equivalent to the per cent. of sugar that was present in the fresh forage. It will be noticed in Table 1 that this is not the case when the analyses are based upon the amount of fresh material. It is interesting here to note in Table I that in some cases all of the sugar was not converted into acid; the silage containing the smallest amount of moisture having the largest per cent. of sugar.

The moisture content of the forage and of the silage being such a variable factor, a table has been compiled, basing the calculations on the per cent. of air-dry matter, of which the sugar is a part. Table 2 shows the relation between the sugar content of the forage and the acid content of the silage made therefrom and is based on the air-dry substance.

1. Found in review of literature, in this thesis. 
Table 2.

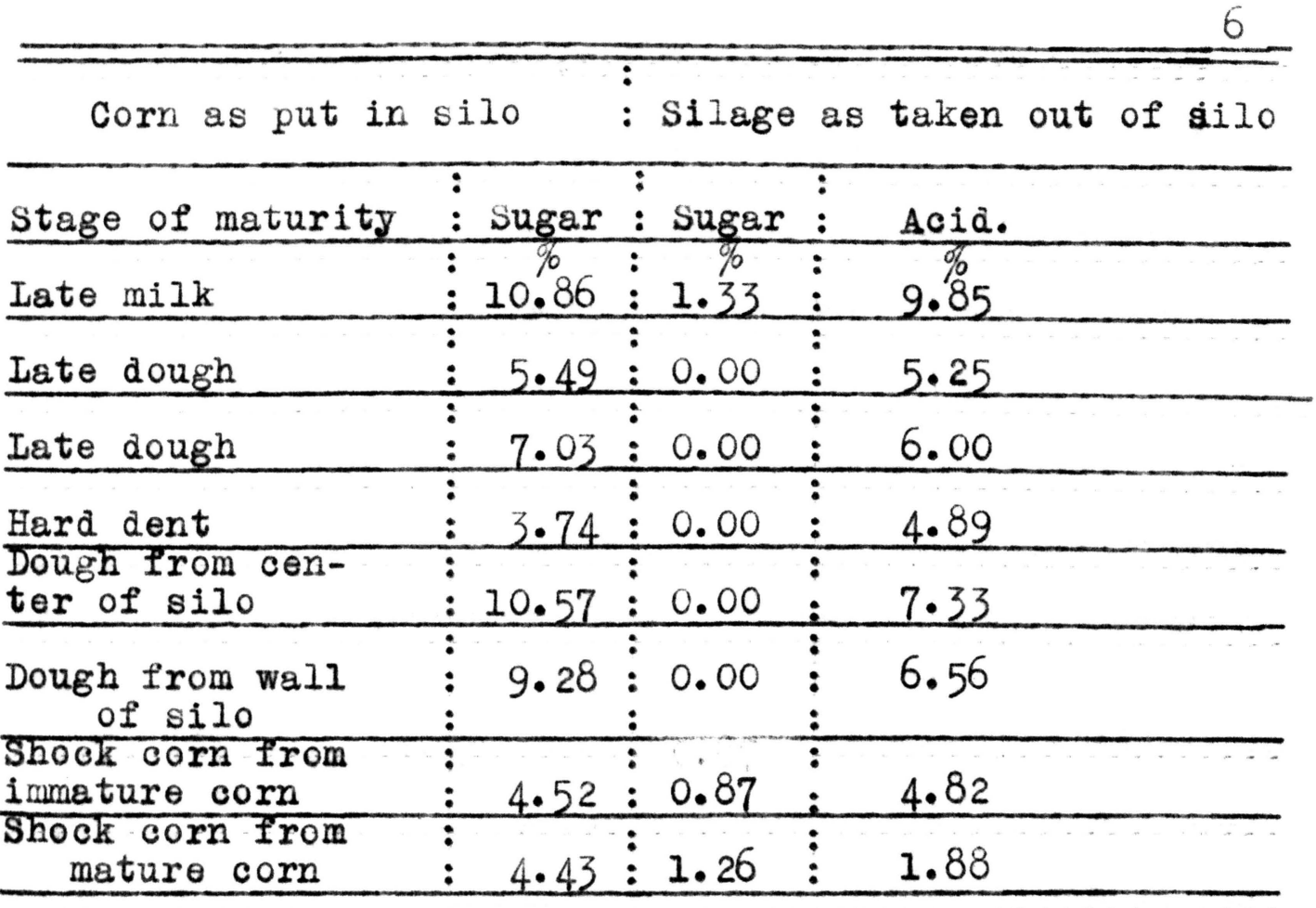

It will be noticed from this table that, in general, there is a definite relation between the sugar content of the forage and the acid content of the silage made therefrom. There was considerable mould in the silage made from the mature shock corn. This may account for the low per cent. of acid in the silage.

There being a definite relation between the sugar content of the forage and the per cent. of acid in the silage, we can conclude that this factor is the cause of the slight variation in the per cent. of acid developed at the wall and in the center of the silo, as there is a highor per cent. of sugar in the center, than at the wall of the silo. 
Kind of Silage:- Moisture and acidity tests

were made of different kinds of silage. Table 3 shows that the nature of the silage crop affects the per cent. of acid in the silage. The crop containing the greatest amount of soluable carbohydrates has the highest per cent. of acid.

Table 3.

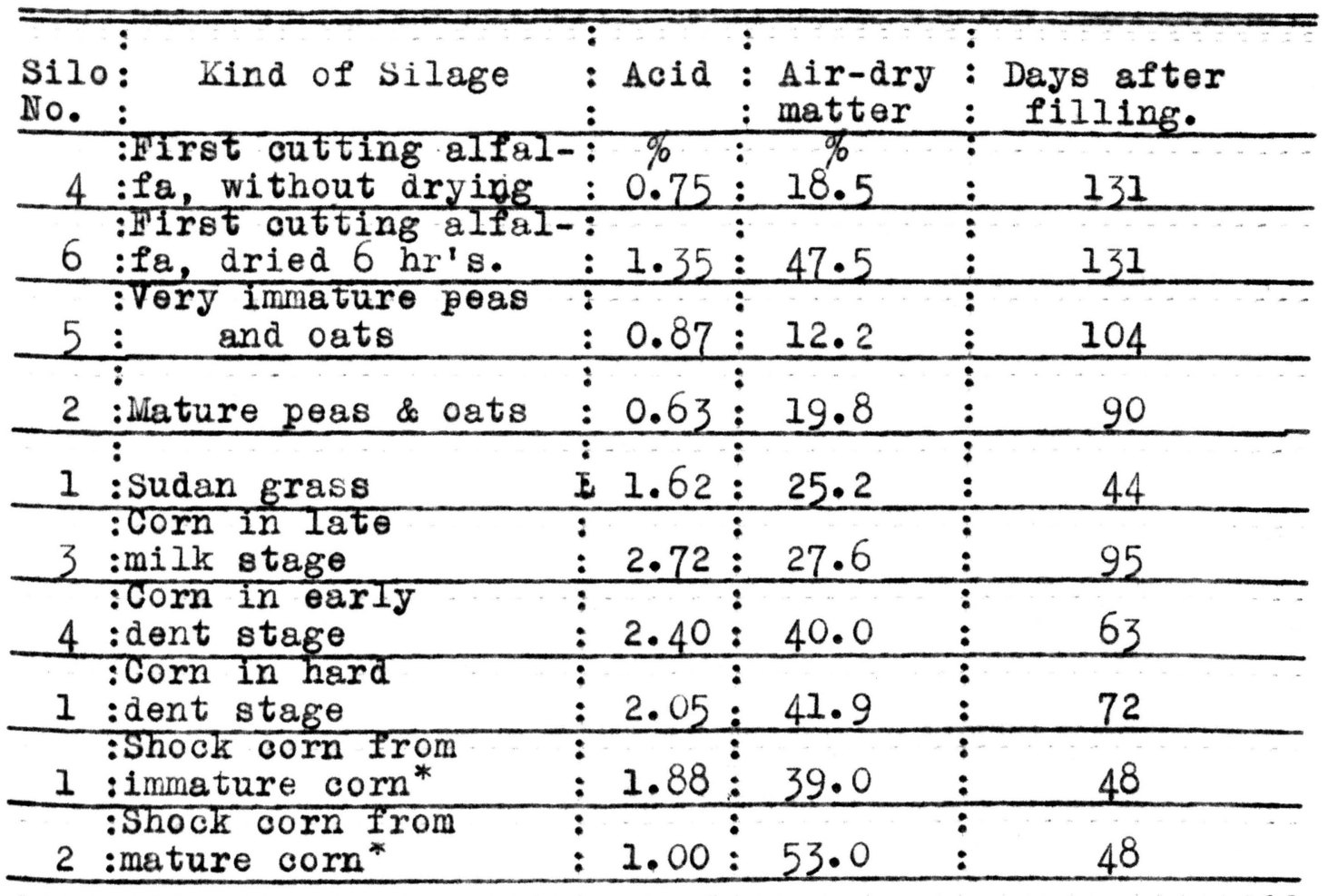

* Water was added to this corn when put into the silo in the ratio of $1: 1$.

These data further support the theory of intramolecular respiration of the plant cell tissue, for from 
many chemical analyses we know that there is a small amount of soluable carbohydrates in the legumes. Table 3 shows that some of the legumes developed as much acid as some of the corn. These results agree quite closely with those shown in Table 13 of Oshel's thesis, as follows.

Table 13.

\begin{tabular}{|c|c|c|c|c|c|}
\hline $\begin{array}{l}\text { Silo } \\
\text { No. }\end{array}$ & : Kind of silage. & : Acid & $:$ & $\begin{array}{l}\text { Air-dry } \\
\text { matter }\end{array}$ & $\begin{array}{l}\text { Days after } \\
\text { filling. }\end{array}$ \\
\hline 2 & Corn & $\begin{array}{l}\% \\
: \quad 2.58\end{array}$ & : & 26.59 & : 134 \\
\hline 3 & Soy beans & $: 0.68$ & $\vdots$ & 26.60 & 57 \\
\hline 4 & Soy beans & $: 1.00$ & $\vdots$ & 25.75 & 158 \\
\hline 5 & Dry corn* & $: 1.74$ & : & 42.08 & 70 \\
\hline 6 & Cowpeas & $: 0.40$ & : & 15.52 & 69 \\
\hline 7 & : Corm fodder & $: 0.89$ & 7 & 39.91 & $\vdots$ \\
\hline $\mathrm{A}$ & $\vdots$ Oats and peas & $: 1.82$ & $:$ & 33.05 & 42 \\
\hline$B$ & Alfalfa & $: 2.05$ & & $47 \cdot 77$ & 53 \\
\hline
\end{tabular}

*Allowed to dry in field until badly in need of water to make normal silage.

Relation Between Moisture and Acidity:- The relation of moisture to acidity is discussed in other parts of this experiment. It might be well to state here that although the acid of the silage seems to bear some relation to the per cent. of moisture in silage, it does not 
bear a direct relation to any one constituent, but seems to be affected by several factors.

Effect of Mould on Acidity:- From a sample of about thirty-three pounds of silage taiken from the center of the North Concrete silo, three samples were taken and treated as described in the plan of this experiment. About four inches of silage was removed from the surface before the sample was taken. This precaution was made because the silage in this silo was a little dry and was found to have molded slightly, to a depth of about three inches after standing a few hours.

Table 4 shows the effect of mould on the acidity of silage. Sample A served as a check sample, sample B was allowed to mold three days and sample $C$ was allowed to mold six days.

Table 4 .

\begin{tabular}{|c|c|c|c|c|c|}
\hline $\begin{array}{l}\text { Sample } \\
\text { No. }\end{array}$ & : & $\begin{array}{l}\text { Days of } \\
\text { Molding }\end{array}$ & $\begin{array}{l}\text { Air dry } \\
\text { : matter }\end{array}$ & Moisture & $\vdots$ \\
\hline $185 \mathrm{~A}$ & $\dot{:}$ & None & $\begin{array}{c}\% \\
\vdots\end{array}$ & $\begin{array}{l}\% \\
65.7\end{array}$ & $\begin{array}{l}\% \\
1.87 \\
\end{array}$ \\
\hline $185 \mathrm{~B}$ & $\dot{\mathbf{g}}$ & Three & 34.1 & 65.9 & 0.23 \\
\hline $185 \mathrm{C}$ & 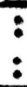 & Six & $37 \cdot 2$ & 62.8 & 0.15 \\
\hline
\end{tabular}

The above table shows that the mould reduces the acidity in silage in direct propdrtion to the length 
of time it is allowed to mold, or in direct proportion to the amount of mould developed.

It was not possible during the experiment to isolate and grow on culture the moulds in the silage, but it is assumed that there are several different species of moulds which develop in silage on exposure to air. The question of what becomes of the acid when it is acted upon by these organisms is of considerable importance, but it was not possible to make a study of it in connection with this experiment. 
LOSSES IN THE SILO.

\begin{abstract}
Object.
The object of this experiment is to determine:
\end{abstract}

1. The unaroidable losses in the silo, brought about by fermentation.

2. The comparative losses in field curing and siloing corn.

In this experiment both loss in total weight

and total nutrients are considered.

\title{
Plan of Experiment.
}

In this experiment, the data was collected from twelve experimental silos and two oil-cloth sacks. The sacks were buried at different depths in the North Concrete silo at the time of filling.

(1) Losses by Fermentation:- Each time an experimental silo was filled a record was kept of the amount of ensilage put into the silo below the screen--a wire screen was placed in each silo, near the top, and enough forage put on top of it to prevent any loss from mould below the screen. The silage was carefully weighed out of each silo. Complete analyses were made of the forage when put in the silo, and again of the silage when taken out. When the North Concrete Silo was about half full a sack containing 25.5 pounds of corn ensilage was buried 
in the center of the silo, when it was about threefourths full another sack containing 25 pounds was buried. Samples were taken of each sack and complete analysis made of them. When the sacirs were uncovered they were carefully weighed, samples taken and analysed.

(2) Field Curing rs. Siloing:- From a pile of about $3 \frac{1}{2}$ tons of corn, cut september 22, 1915, at the beginning of the dent stage, from the same field, eight lots of 800 pounds each were made, by adding one or two stalks at a time to each lot until the total weight was 800 pounds per lot. These lots were designated as lots No. $1,2,3$, etc.

Lots NO. 1 and 2 were brought in immediately, run through silage cutter, sampled, and lot No. 1 woighed into silo No. 5, and lot No. 2 weighed into silo No. 6. These silos were used as a check on the other six lots in the series.

Lots No. 3 to 8 inclusive, were shocked in the field and a rat proof fence build around them.

Lots No. 3 and 4 were brought to the barn December 15. carefully weighed, run through cutter, and again weighed together into silo No. 5 after the silage from lot No. I had been removed. Water at $38^{\circ} \mathrm{F}$. was added in the ratio of $1: 1$. 
Lot No. 7 was brought in at the time Nos. 3 and 4 were put in the silo. It was carefully weighed and fed out, on frozen ground to cattle. The refuse was gathered as thoroughly as possible and weighed.

Lots No. 5 and 6 were brought to the barn February 14, 1916, carefully weighed, run through cutter, then weighed together into silo No. 6 after silage from Iot No. 2 was removed from the silo. Water at $60^{\circ} \mathrm{F}$. was added in the ratio of $1: 1$. This silo was emptied April 15.

Lot No. 8 was brought in at the time Nos. 5 and 6 were put in the silo. It was weighed and fed out to cattle in the same manner as Iot No. 7. The refuse was gathered and weighed.

Each time a silo was filled, and again when it was emptied a sample was taken and analysed,

\section{Discussion of Data.}

Lossed by Fermentation:- The data collected on this subject were obtained from twelve experimental silos, on one of which the data are not complete. Data collected from silage in the two oil-cloth sacks, which were buried. in the North Concrete Silo are also considered. As each silo was filled one or more times during the experiment the sample number of the silage will be used as the num- 
ber of the silo.

The analyses of the silage from the twelve silos and from the two oil-cloth sacks is shown in Table 5. The data in this table are based upon the weight and the analyses of the air-dry matter below the screen.

\section{Table 5 .}

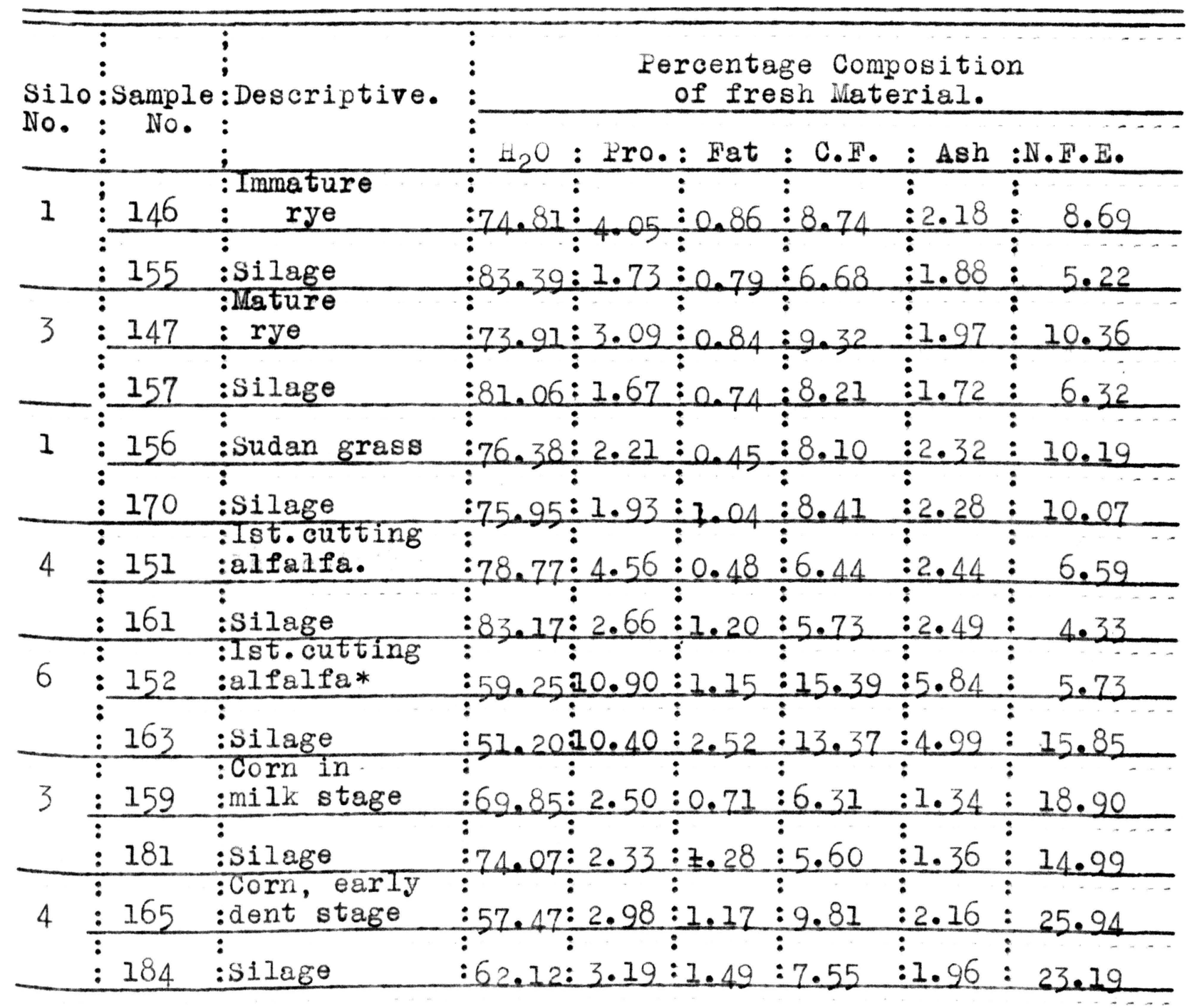

* This alfalfa was allowed to dry in the sun for six hours. 
Table 5 cont'd.

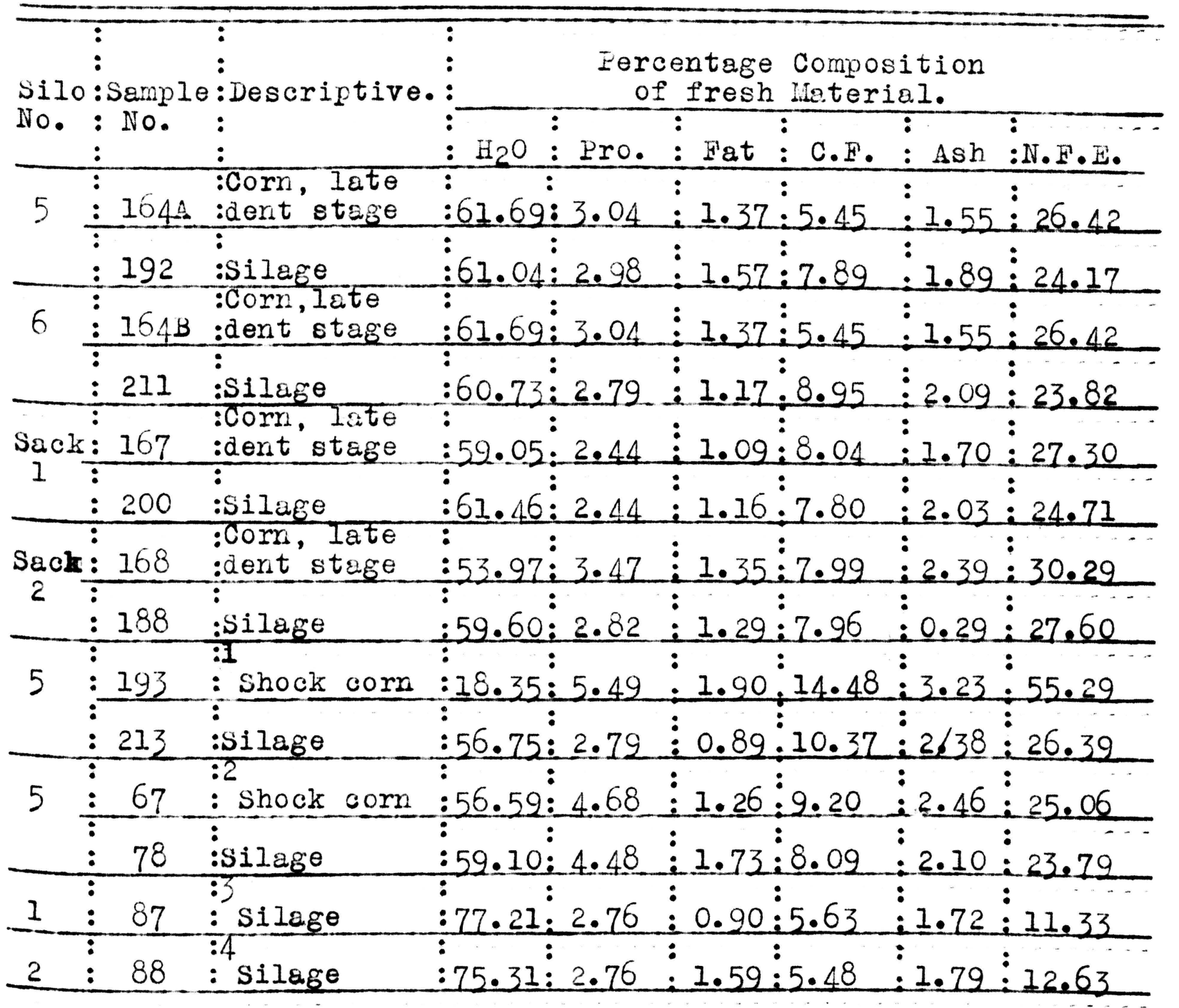

1. Water was added in the proportion of $1: 1$.

2. Water was adaed in the proportion of 1 of water to 8.8 of fodder.

3. Fron a silo in which the silage was not packed at all so that mould would develop.

4. From a silo in which the silage was well packed. Check on No. 87. 
From the aralyses of the forage as put into the silo and of the silage removed, we can see that there is a decrease in the smount of all the constituents, except that of fat. The analyses show that in most cases there is a sight increase ir the amount of fat during the process of silage formation. However, this increase may not be due to the breaking fiown of protein, as is sometimes suspected, but is probably due to the chenging of some fats, insoluable in ether, to a soluable form. The fat reported in these analyses is the total ether-soluable matter.

In some cases there was a very great reduction in the amount of protein during silage formation. This reduction was in direct progortion to the extent of fermentation. It will be noticed from the table that the higher the per cent. of moisture in the forage, when put into the silo, the greater was the loss in protein, and the more rapid the fermentation, as shown by the condition of the silage when the silos were emptied. For example: On comparing silage from silos Nos. 4 and 6 , in which the first cutting of alfalfa was put, it will be noticed that in silo No. 4 there was a reduction of about $40 \%$ in the amount of protein during 


\begin{abstract}
silage formation, whereas in silo No. 6 , there is practically no change in the amount of protein. The alfalfa put into silo No. 6 was the same as that put into silo No. 4; but it was allowed to dry so as to reduce the amount of moisture from $78.77 \%$ to $59.25 \%$ These results are more clearly shown in Table 6. This table gives the percentage losses occuring in the silo during silage formation. These data are based upon the total weight of the material below the screen in each silo.
\end{abstract}


Table Ho. 6.

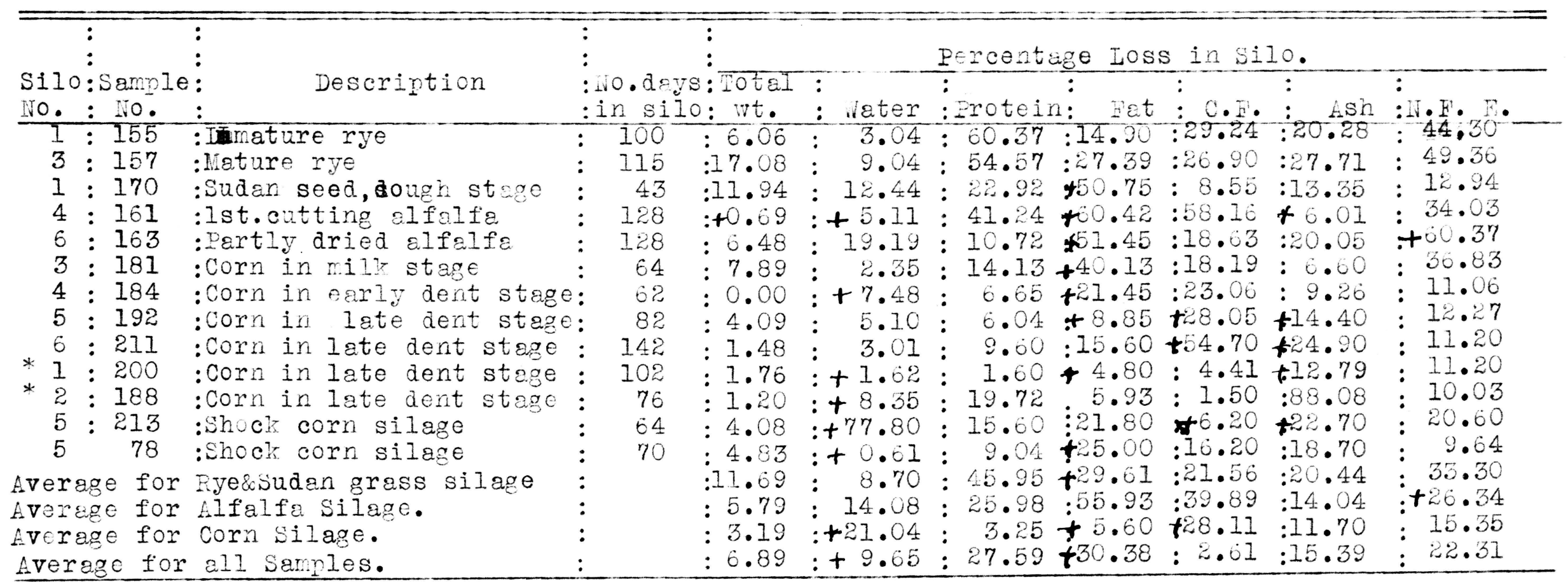

*silage in sack. 
It will be noticed in Table 6 that there was a loss in total weight, from $0.00 \%$ to $17.08 \%$, the average being $6.89 \%$. Silo 161 shows a gain of $0.69 \%$ in total weight, which is due to the water settling from the layer of silage above the screen. There is a gain in water in some of the silos while in the others there is a considerable loss in moisture. The reason for this gain is given above; the loss is accounted. for by the fact that some of the ilos leaked. There was an average gain of $9.65 \%$ in moisture in all of the silos.

There was a loss of from $1.60 \%$ to $60.37 \%$ in the amount of protein, the average 10ss being $27.59 \%$. It will be noticed that there was a gain of $6.65 \%$ in silo 184. The silage from this silo was in excellent condition, making the best silage of any corn in the experiment. The corn was in exactly the proper condition for siloing when cut. The gain in protein content in this silo was due to the fact that there was not as great fermentation and breaking down of the protein into amino acids as there was in Silo 181. This silo shows a loss in the amount of protein, but about $50 \%$ greater gain in fat or ether-extract than in Silo 184. In every case where the fermentation in the silo was about normal, there was a gain in 
ether-extract during silage formation, the average gain being $30.38 \%$. This gain was probably due to the breaking down of protein into amino acids. Where there was an excessive fermentation, as indicated by the character of the silage when removed, there was a loss in ether-extract, due to the further breaking down of the amino acids into fatty acias and ammonia. The fatty acids were further broken down into gases wich were given off. Although it is probable that the gain in the ether-extract was due to the above causes, it is possible that some of the ether-insoluble fats were converted into ether-soluble fats during the process of silage formation.

There was a loss of from $1.50 \%$ to $58.16 \%$ of crude fiber in the silos, the average being $2.61 \%$. This loss is due to the breaking down of the pentosans into a more soluble form. It will be noticed that Silos 192 and 211 show an increase in crude fiber, which is accounted for in the fact that there was considerable mould in the se two silos.

The data on ash show a loss of from $6.60 \%$ to $88.08 \%$, the average being $15.39 \%$. This constituent varied with the condition of the sample, depending upon the amount of foreign material in the sample. This variation was very great, as shown in some cases where 
there was even a gain in ash.

The loss in nitrogen-free extract varied with the loss of the other constituents, the loss increasing as the loss in nitrogenous substance decreased. The loss of nitrogen-free extract varied from $9.64 \%$ to $49.36 \%$ and averaged $22.31 \%$.

It will be noticed from the average of the different kinds of silage, that the greatest loss was in the silage made from the small cereal crops. The loss in total weight was $11.59 \%$ for the silage made from the small cereals, $5.79 \%$ for the legume silage, and 3.19\% for the com silage. This difference was due to the fact that the corm did not have as great a loss in moisture during the siloing period as the cereals and legumes. From the data in Tables 4 and 5 we can conclude that when the forage of the small cereal and the legume crops have about $37 \%$ of air-ary matter at the time of siloing, good silage can be made from them - Corn forage should not contain quite as much air-dry matter at the time of siloing as the legume and small cereal crops. Field Curing vs. Silo Curing:- In considering the relative value of these two methods of preserving the crop, it must be remembered that it is impossible to preserve any crop by any method now known without some loss. It was hoped in the beginning to have more data than those 
which are presented in the consideration of this experiment, but it was impossible to secure all of the analyses in time to present them in this paper. A composite sample of Shocks 1 and 2 was used as the analysis of all of the corn shocked in the field. This analysis, and the analysis of each shock as it was taken from the field, is shown in the following table.

Table 7 .

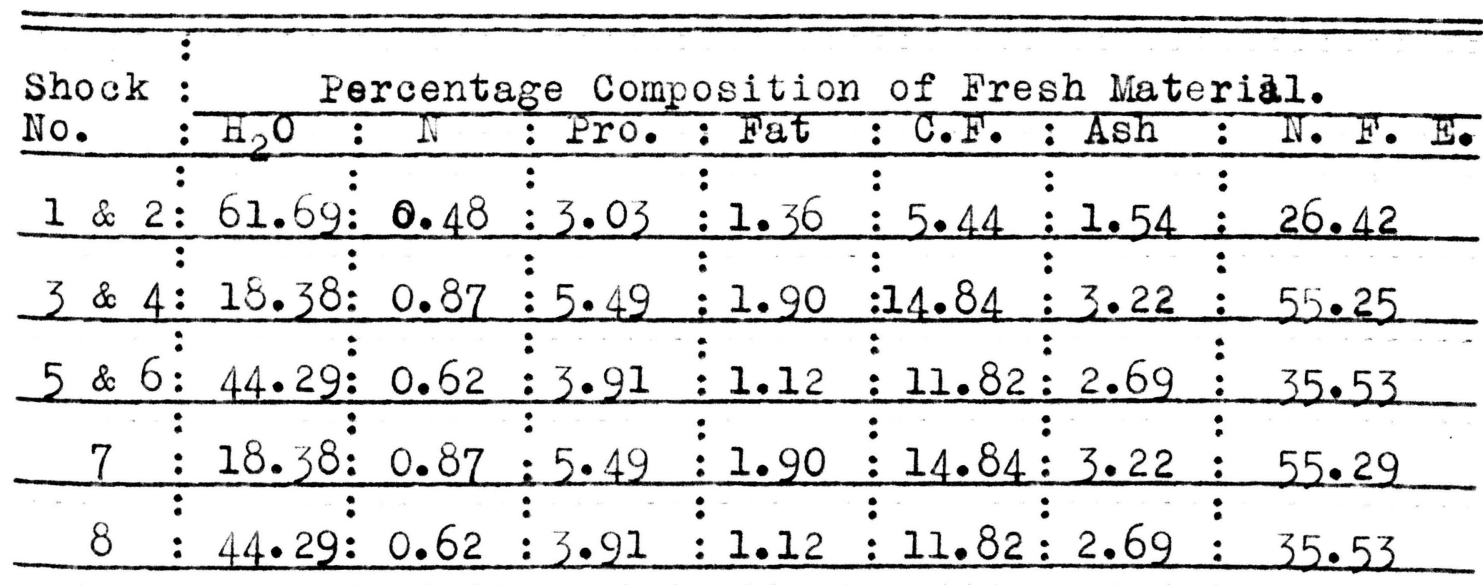

As stated in the plan of this experiment, Shocks 1 and 2 were put in Silos 5 and 6 respectively. Shocks 3, 4, and 7 stood in the field 75 days; Shocks 5,6 and 8 stood in the field 134 days.

It will be noticed from the analyses that there was an increase in all of the constituents, except that of fat, during the time the corn was in the shocks. Thid does 
not necessarilly mean a total increase in the constituents, as the analyses were made on the basis of the fresh material, and were greatly affected by the per cent. of air-ary substance when the samples were taken. This fact is show more clearly in the following table. It shows the per cent. lost in shociss 1 and 2 which were put in silos, as compared to the loss in the shocks in the field for the same length of time.

\section{Table 8.}

Comparative Loss in Field Curing and Siloing

Corn.

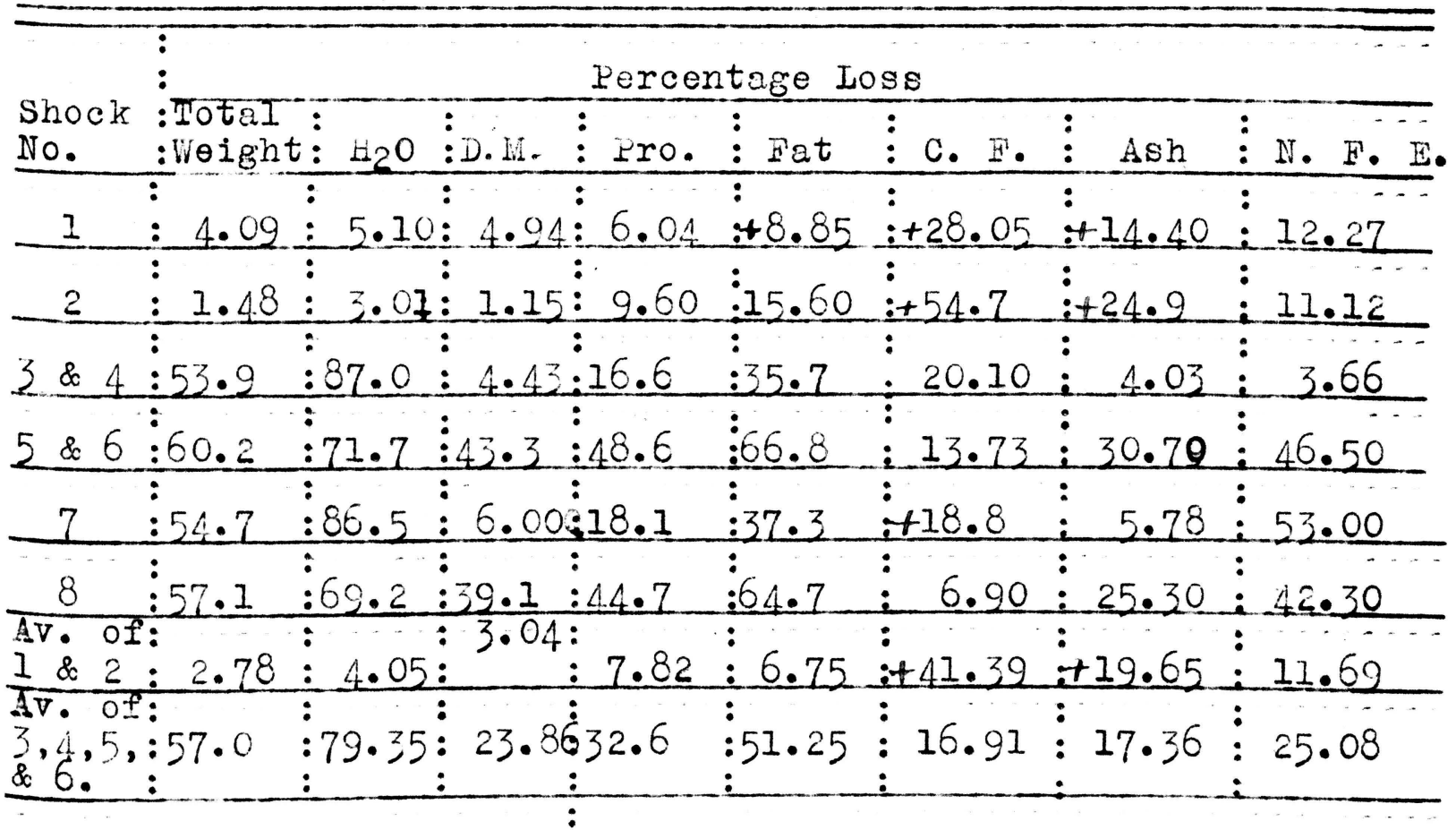


The loss of nutrients ir shocks 1 snd 2, which were put in silos 5 and 6 after cutting, has been discussed under Table 6. It will be noticed that the data in Table 8 show a loss by field curing about $87 \%$ greater than that incurred by putting the corn in the silo. The greatest loses were in the amount of protein and of fat, two of the most important constituents of feed stuffs. It will be remombered, however, that shocks 5 and 6 stood in the field 134 days, or 49 days longer than shocks 3 and 4. These 49 days were in December and January, and February, when we have the most severe weather. Referring to Table 8 again, it will be noticed that the greatest loss in rutrients occurred during this period. Table 9 shows the comparative loss of putting shock corn in the silo after standing shocked in the field from september until December--a period of 74 days, with leaving corn in the field urtil February, or 49 days longer.

\section{Table 9 .}

* Comparative Loes in Siloing Shock Corn and Leaving it in the Field.

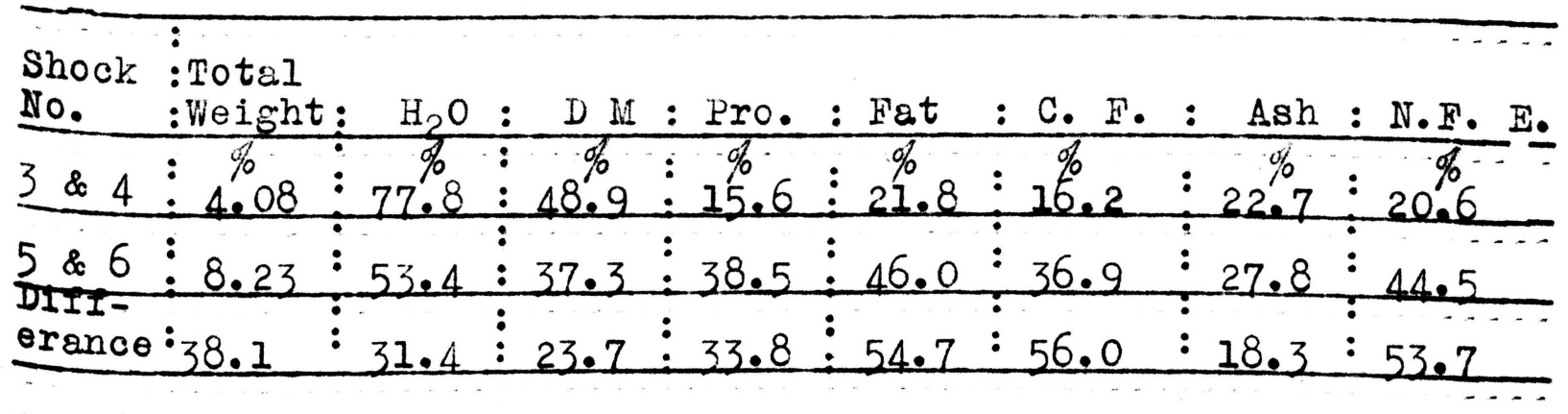

*Shocks 3 and 4 were in the silo 60 days. Shocks 5 and 6 were in the field during the same period. 
In the calculation of the data in the above table, the average weight of shocks 3 and 4 was taiken as the average weight of shocks 5 and 6 when shocks 3 and 4 were put in the silo on December 15th.

In consideration of data in Table 9 , it will be noticed that there was a much greater loss of nutrients in shock corn left in the field than in the shock corn put in the silo. It will be further noticed, however, that there was a greater loss, of the total dry matter in the silo, but this varies with the amount of moisture, as shown in the table. Shocks 5 and 6 gained only 31.4\% as much moisture as did Shocks 3 and 4 in the silo. The great gain of moisture in the silo is of course due to water added at the time of filling. As pointed out in the discussion under Table 8 , there was a greater loss in shock corn during the three winter months than there was in the first months after it was shocked in the field. Table 10 shows this comparative $10 \mathrm{ss}$ in shocks 5 and 6 . 
Table 10.

Percentage Loss in Shock Corn from sept. 22 to Dec. 15, and from Dec. 15 to Feb. 15.

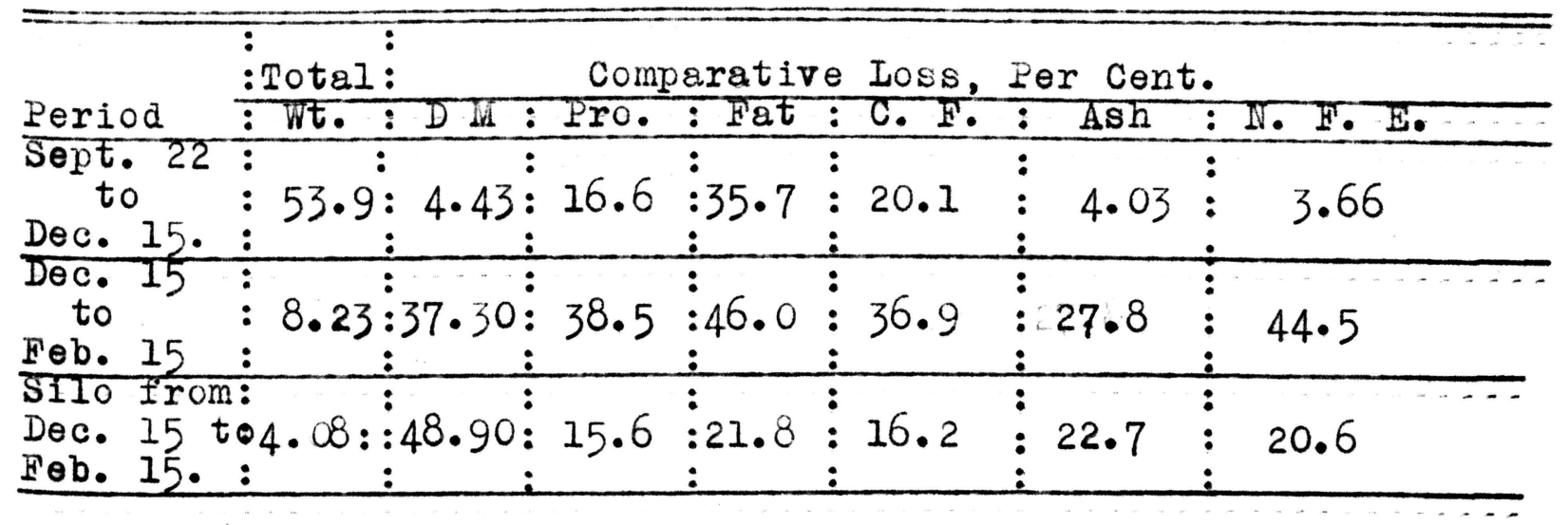

It is shown by the data of the above table that there was about $65.0 \%$ greater loss in total nutrients during the second than in the first period. The last line of Table 10 shows that there would have been but a very small loss in nutrients if the two shocks had been put in the silo December 15.

From data obtained by feeding shock 7 to cows in the barn-lot, December 15, we have further evidence of the advisability of putting shock corn in the silo. When shock 7 was fed to cows it was found that there was a loss of $20.0 \%$ in total weight; that is 20 pounds out of every 100 of shock corn fed was refused. This loss increased with an increase in the length of time the com remained in the field. Shock 8 was taken from the 
field in February and it was found that there was a loss of $32.0 \%$ when fed to the cows. The data in Table 9 show that there was a loss in nutrients and from this fact, shown by data obtained from feeding shocks 7 and 8 to cattle, we can see that the palatability of the fodder decreases in proportion to the time it remains in the field. From these data we feel safe in concluding that it is more profitable to put shock corn into the silo in the fall of the year than to leave it in the field through the winter months. 


\section{IEGUIES FOR SIIAGE.}

\section{Object.}

In recent years there has been consiajerable attention given to the legume crops for silage purposes. The object of this experiment is to determine in part the conditions under which alfalfa, and pea and oat crops can be siloed.

\section{Plan of Experiment.}

Experimental silos were filled as follows:

No. 4, filled May 13, 1915 with first cutting of alfalfa. No. 6, filled May 13, 1915, with the first cutting of alfalfa, but was allowed to lay in the direct sunlight six hours before putting in the silo.

No. 5, filled June 9, 1915, with immature peas and oats. No. 2, filled July 2, 1915, with mature peas, and oats in the dough stage.

A record was kept of the amount put into each silo, and of the amount of silage weighed out. Samples were taken and analysed, both at the time of filling the silos, and again when they were emptied. 
Discussion of Data.

Alfalfa:- Experimental silos 4 and 6 were filled with the first cutting of alfalfa, as shown in the plan of this experiment. The forage was cut in $\frac{3}{4}$ inch lengths and thoroughly tramped into the silose

When these silos were emptied, 128 days later

it was found that the silage in No. 4 had settled to onehalf its original volume while the silage in No. 6 hed settled to only four-fifths its original volume--the latter is the normal shrinkage in the experimental silos. The silage from No. 4 had a very disagreeable odor and appeared to be very badly decomposed. The cows refused to eat this silage. The silage in No. 5 was in good condition, though it was a little dry, as shown in Table ll, colum 3. From all indications this alfalfa made better silage than any of the legumes. The cows ate this silage very greedily.

Table 11 shows the composition of alfalfa put into, and of the silage removed from silos 4 and 6 . 
Table 11.

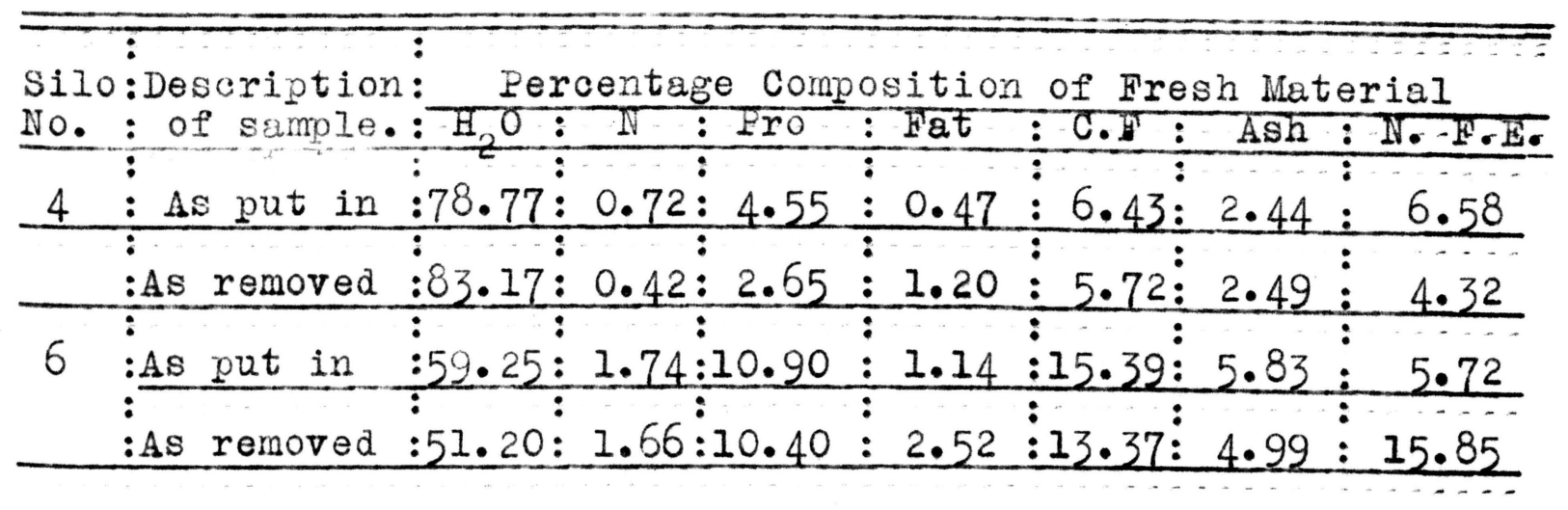

*Allowed to ary in the sun for six hours before putting into silo.

Table 11 shows a decrease in the percentage composition of alfalfa when made into silage. The greater loss is in the silage having the higher per cent. of moisture. It will be noticed from this table that there is a slight increase in the per cent. of fat. This was brought about by the hydrolysis of some of the volatile acids into fats. These results are shown more clearly in Table 12, which gives the total weight of the material weighed into the silo, the amount weighed out, the loss in pounds and the percentage loss. 
Table 12.

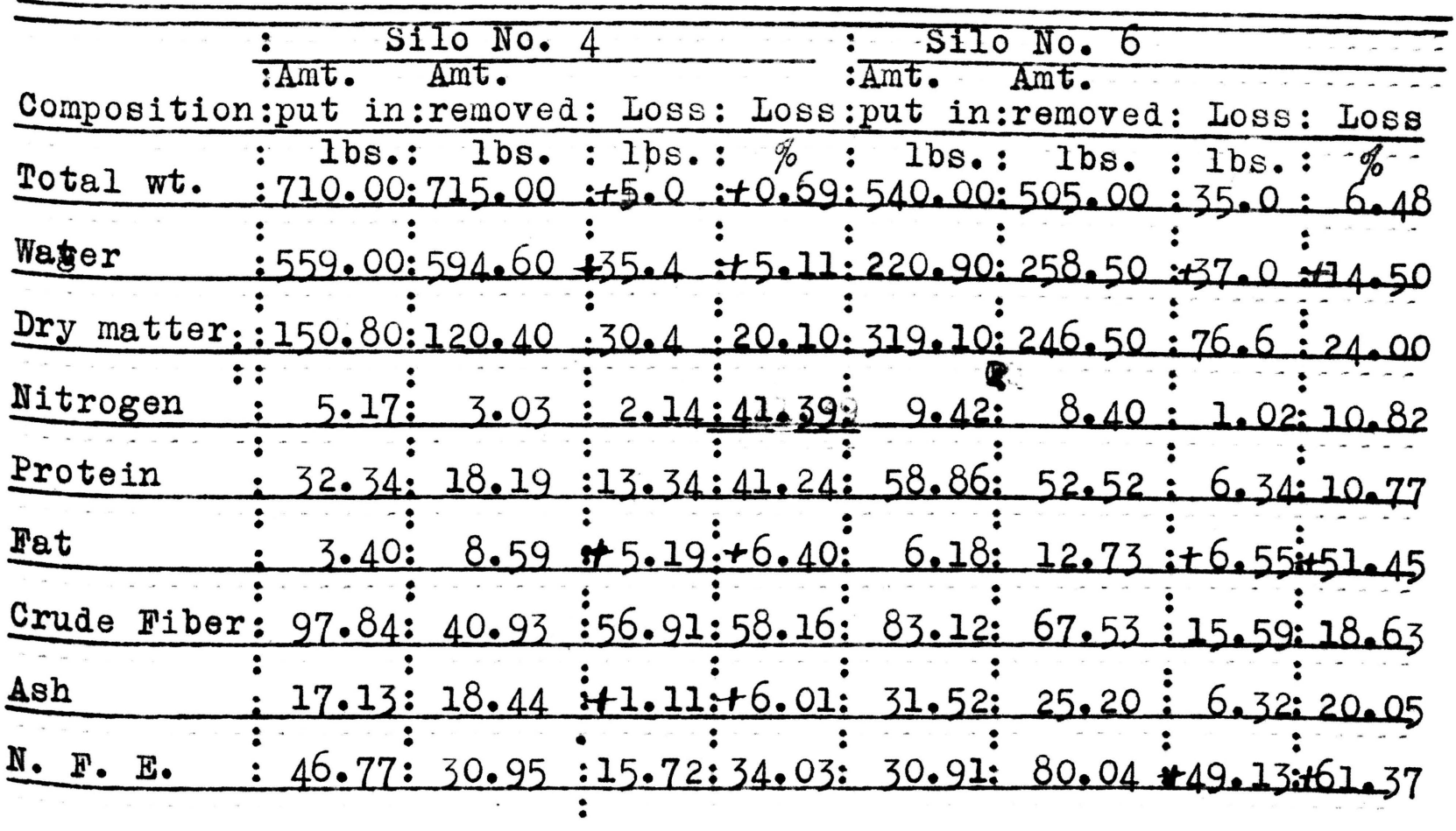

The above table shows that on an average the loss in total nutrients was considerably more in silo No. 4 than in silo No. 6. However, the greatest loss in both silos was in protein. It will also be noticed that there was a loss of $34.03 \%$ of nitrogen-free substance in silo No. 6. There was only $0.75 \%$ acid developed in silo No. 4 while the silage in No. 6 had $1.35 \%$ acid.

From these data we can conclude that the best results in siloing alfalfa are obtained when the forage 
contains about $65 \%$ moisture at the time it is put into the silo.

Peas and Oats:- Experimental silo No. 5 was filled with very immature oats and Canada field peas. The oats and peas were taken from a field that was sown at the rate of three parts oats to two parts of peas. The forage was cut in $\frac{3}{4}$ inch lengths and thoroughly packed into the silo. It contained only $14.18 \%$ of dry matter when put in the silo and $11.64 \%$ when taken out. When this silo was opened after 104 days, it had settled to nearly one-half its original volume. The silage had a very strong, disagreeable odor and contained only $0.87 \%$ of acid. The cows refused to eat this silage. There was a loss of $22.09 \%$ in total weight and about $33.0 \%$ in dry matter in the silo.

Silo No. 2 was filled with peas and oats more mature than the material put into silo No. 5. Some of the peas were mature and the vines were very woody. The oats were in the dough stage. This forage was taken from a field which was sown at the rate of three parts of peas to two parts of oats. It had $19.96 \%$ of ary matter when put into the silo and $18.16 \%$ when taken out. There was a light rain on the forage when the silo was being filled. When the silo was opened after 89 days, the silage had settled to about two-thirds of its original volume. 
There was a considerable amount of water in the bottom of the silo and the silage had a very strong pungent odor. It contained only $0.63 \%$ acid. However, there was a loss of only $15.7 \%$ in weight and $19.0 \%$ in air-dry matter. The cows ate this silage but did not seem to relish it. 


\section{SHOCK CORN SILAGE.}

\section{Object.}

Previous work along this line indicates that fairly good silage can be made from shock corn fodder, when water, from $60^{\circ} \mathrm{F}$. to $70^{\circ} \mathrm{F}$. is added in sufficient quantity, and the silo filled slowly.

The object of this experiment is to determine: 1. The loss of nutrients in silage made from shock corn. 2. The relation of the sugar content of the forage to the acidity of the silage.

Plan of Experiment.

On September 24, 1915, corm, in the dough stage was cut and shocked in the field. This shock was brought to the barn December 17, run through silage cutter and put in experimental silo No. 1.

September 22 corn, in the soft dent stage was cut and shocked in the field. The shocks were brought to the barn December 15, run through cutter and put in experimental silo No. 5 .

September 23, corn in the hard dent stage, was cut and shocked in the field. This shock was brought to the 
barn December 17, run through cutter and put in experimental silo No. 2.

When these silos were being filled water at $60^{\circ} \mathrm{F}$. was added to both of them in the ratio of $1: 1$. Samples were taken of some of the forage, after being run through the cutter, when the shocks were put up in the field, and analysed. Samples were again taken when the shocks were put in the silos and when the silage was removed, and analysed. All of these silos were emptied February 12, 1916.

\section{Discussion of Data.}

silo No. I was opened 55 days after being filled. It sustained a loss of only $0.14 \%$ in total weight but showed a loss of $59.4 \%$ in dry matter. The silage showed an excess of mould near the top of the silo. There was a loss of silage below the screen of about eighty pounds, due to mould, However, this loss was not included in the calculation of the losses given above. The silage was very dry; which accounts for the development of the mould in it. The great loss in silage, caused by mould near the top of the silage was due to the settling of the water in the silo. It was found that the corn fodder would not take up the water as fast as the silo was filled, and there was an excess 
moisture in the silage near the bottom of the silo. Although the silage was a little dry and contained considerable mould, it was otherwise similar to silage made from green corn.

Silo No. 2 was opened 55 days after filling. The silage in this silo sustained a loss of only .016\% in total weight but there was a loss of $36.9 \%$ in arymatter. Although the silage appeared to be normal in every respect to silage made from green corn, it had developed considerable mould around the top. There was a loss 120 pounds of silage from mould, near the top, This was due to the water settling in the silage, leaving the top very dry.

Silo No. 5 was opened 64 days after it was filled. The silage was in practically the same condition as that removed from Silos 1 and 2. There was a loss of 129.5 pounds of silage near the top of the silo, caused by mould. However, this moldy silage was included in the calculations of the losses in the silo, and a portion of the moldy silage was taken as a part of the sample which was analysed. Whth the exception of the loss from mould near the top of the silo the silage appeared to be normal in every respect to silage made from green corn. In Table 13 the amount of fresh material, and of each constituent weighed into silo 
No. 5 are given, and also the amount weighed out, the loss in pounds, and the percentage los.

It was hoped in the beginning to have more date on this subject, but it is not jet arailable.

\author{
Table 13. \\ Losses in silo No. 5 in $1914^{*}$ \\ anà 1915.
}

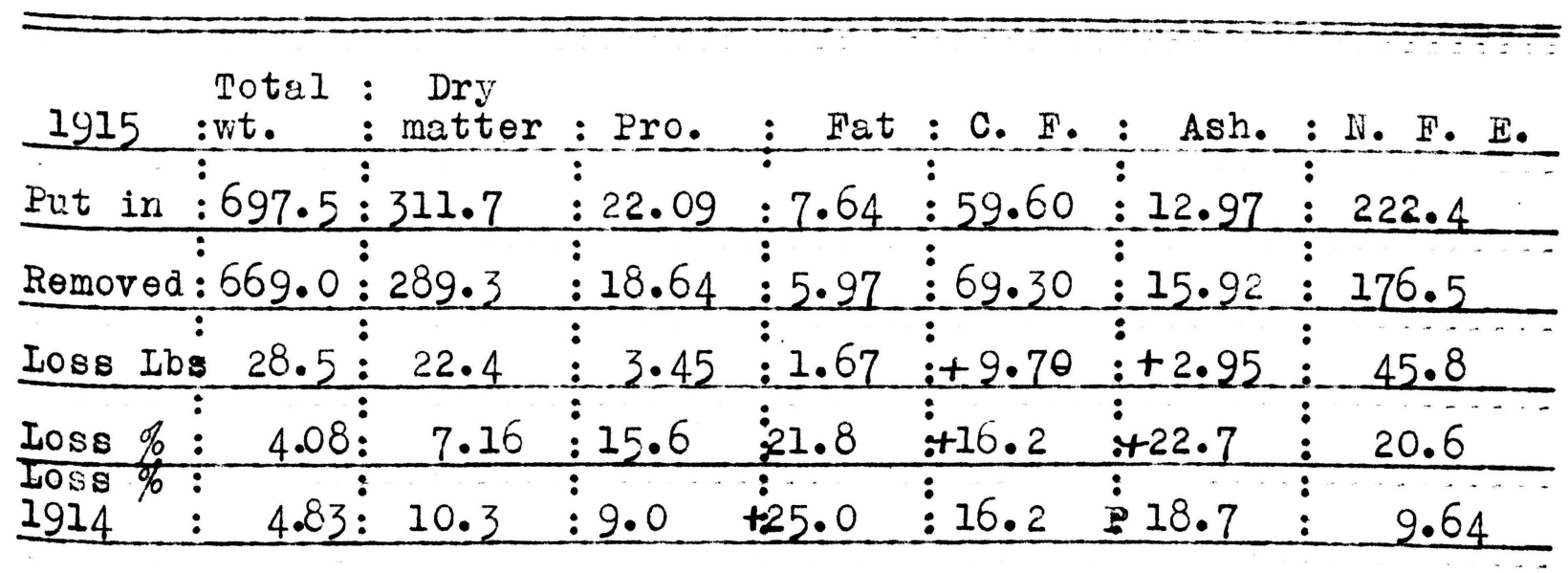

*Same silo used in another experiment in 1914.

It will be noticed from this table that the average loss in silage made from shock corn was about the same as the loss in silage made from green corn. There was an increase in crude fiber and ash in the silo in 1915. This was due to the development of a large amount of mould in this silo. Relation of Sugar to Acidity:- The corm used for Silo No. 1 contained $4.08 \%$ of sugar when shocked in the field, 
4.01\% when put into the silo, and the silage contained $0.33 \%$ of sugar when it was removed from the silo. The silage developed $1.88 \%$ of acid.

The corn for silo No. 2 contained $3.6 \%$ sugar when shocked in the field, $3.6 \%$ when put into the silo, and the silage had $0.66 \%$ of sugar when taken from the silo. This silage developed only $1.00 \%$ acid. The above data were based on the weight of the fresh corn as put into, and of the silage removed from each silo. Calculations based upon the per cent. of airdry matter in each silo were also made. When put on this basis the per cent. of sugar in the corn had the same relation to the acid in the silage as was shown in the calculations based on the fresh material.

From these data we can see that the higher the sugar content of green corn, when shocked in the field, the greater is the amount of acid developed in the silage. Although these data show that there is a direct relation between the sugar content of the green forgge and the acid content of the silage made therefrom, we would not feel safe in drawing any definite conclusions from these results. As pointed out under the discussion of data under "The Effect of Mould on Silage", mould greatly reduces the acid in silage. The silage from silos 1 snd 2 contained considerable mould, and was therefore the probable cause of the low per cent. of acid in the silage. 
OIHER CROPS FOR SIIAAGE.

Object.

The possibility of growing rye to be followed by another crop makes it important to know if this crop can be put into the silo with success. The interest in sudan grass, makes it advisable to try it as a silage crop. There-fore, the object of this experiment is to determine under what conditions these two crops can be siloed.

\section{Plan of Experiment.}

In this experiment three experimental silos were used. Two were filled with rye and one with Sudan grass.

April 27, 1915, silo No. I was filled with immature rye, just beginning to head out, after being run through a silage cutter.

May 5. Silo No. 3 was filled with rye from the same field. It was in the bloom stage, the stems beginning to get woody.

August 17, silo No. I was filled with sudan grass after the rye silage had been removed. The sudan grass when cut was about seven feet high, the stems a 
little woody, and the grain in the dough stage. It was run through a silage cutter and put in the silo in the usual way.

$$
\text { Records were kept of the amount put in each }
$$

silo and of the amount of silage weighed out. Samples were taken and analysed, both at the time of filling the silos and again when they were emptied. The amount of acid was also determined in a sample from each silo when the silage was removed.

\section{Discussion of Data.}

All of the crops were cut in $6 / 8$ inch lengths and put into the silos as soon as possible after it was brought in from the field. When the silos were opened it was found that the volume of silage in each silo containing rye had decreased to about one-half its original volume. This was due to the rye having a hollow stem, necessarilly incorporating considerable air at the time of filling, which was pressed out during the period of silage formation.

$$
\text { Rye:- The rye silage was removed from silo }
$$

No. 1,98 days after being filled. It had a good straw color and a typical silage taste; the odor, however, 
was very disagreealle, The cows ate the silage greedily. The silage frov wilo No. 3 was removed after being in the silo 105 days. It was in good condition, but the cows did not seem to relish it, as much as they did the silage made from the less mature rye. Acidity tests were not made on any or the rye silage. Table 14 gives the composition of rye put into, and of the silage renoved from silos 1 and 3 .

Table 14 .

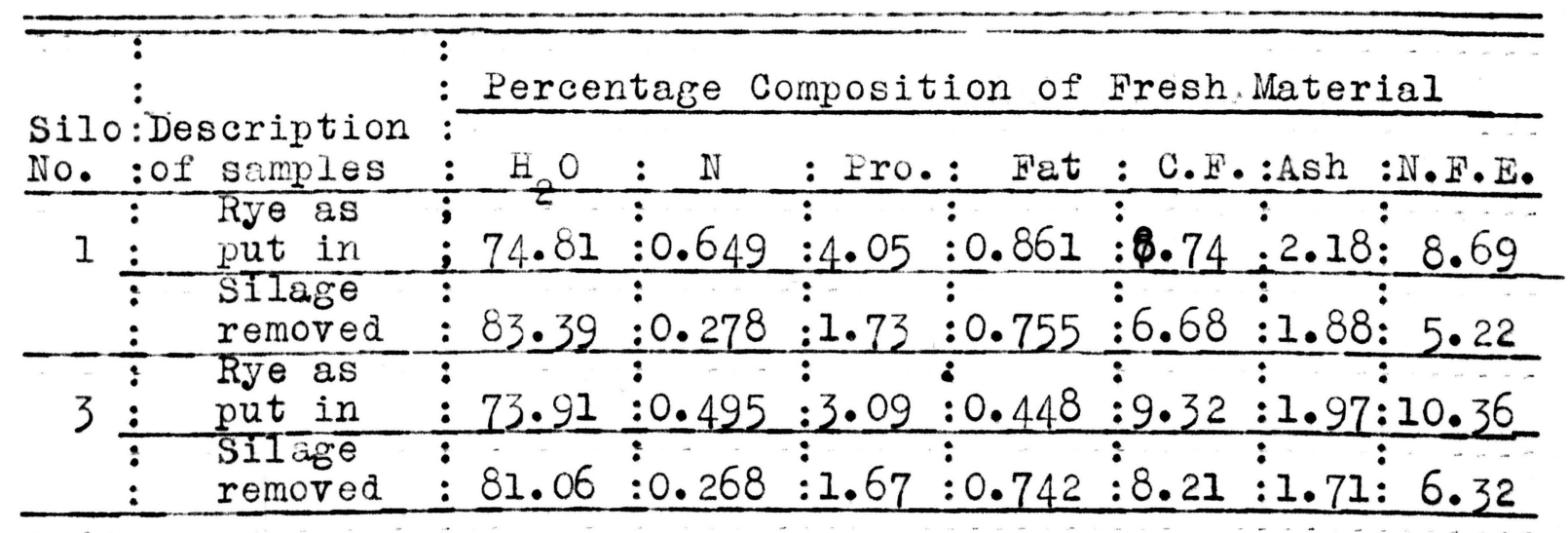

The average percentage decrease of all constituents during the process of silage formation was about the same in both silos. With the exception of crude fiber and nitrogenfree extract, all of the constituents were lower in silo No. 3 than in silo No. 1 . 
Table 15 gives the weight of the fresh material and of the total constituents weighed into silos 1 and 3 , the amount weighed out, and the per cent. loss in each.

Table 15 .

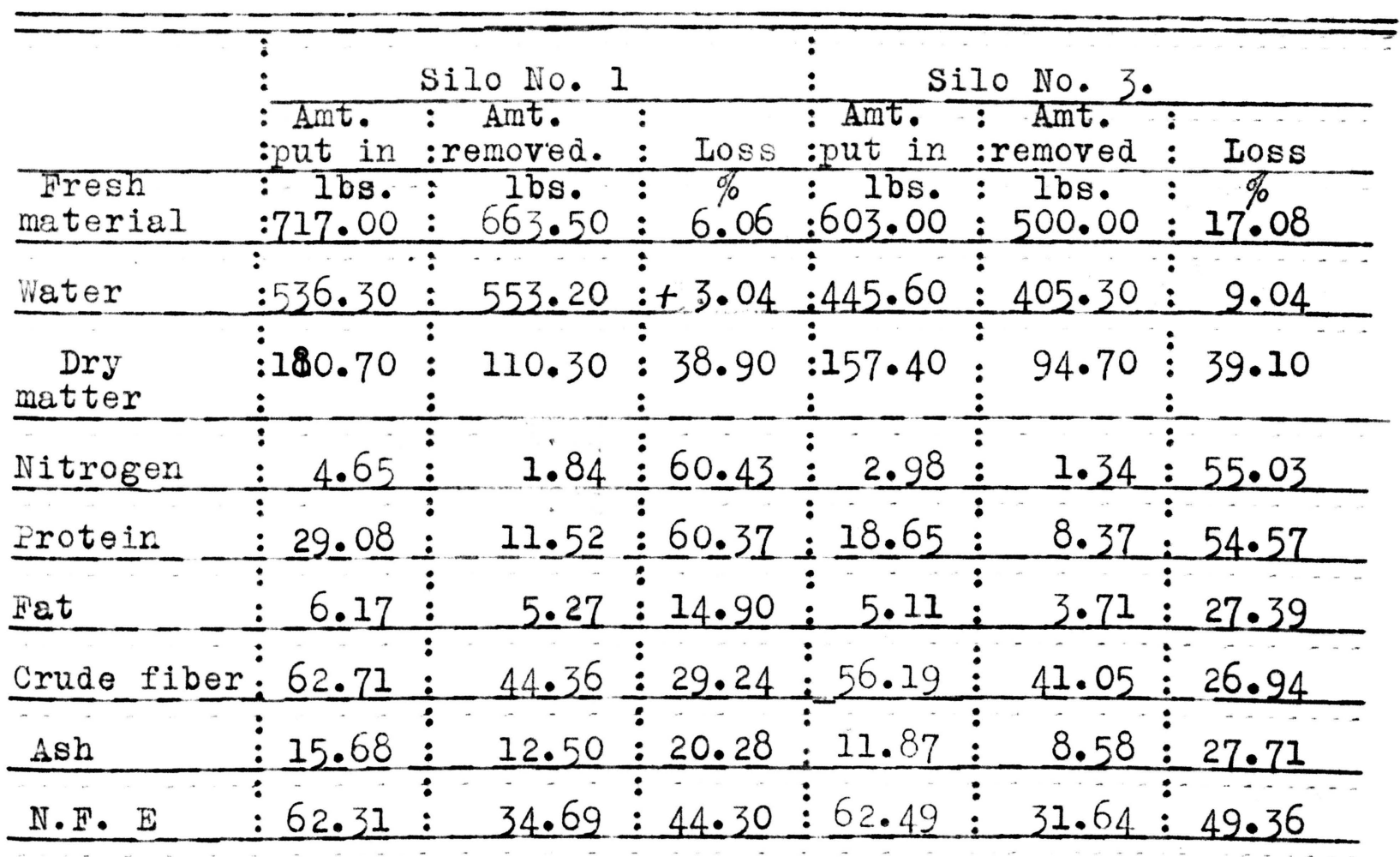

With the exception of nitrogen and protein, there was a much greater loss of nutrients in silo No. 3 than in silo No. 1. It will be noticed that in Table 15 there was not an increase in the amount of fat, or ether-extract, in rye silage. Other experiments reported in this thesis 
show that in nearly every case with corn silage, and silage made from legume hays that there was an increase in the amount of fat during silage formation. This was probably due to the breaking down of some of the volatile fats into alcohol which was acted upon by the yeasts, normal to silage, and converted into acetic acid. The acetic acid is further broken down into gases which are liberated.

Sudan Grass:- Silo No. 1, containing Sudan grass silage was opened 43 days after it was filled. As previousIy stated, the silkge had settled considerably, but not as much as the silage made from rye. The silage was free from mould and contained $1.62 \%$ acid. It had a good silage odor and the cows ate it greedily, in fact, they seemed to prefer it to corn silage.

Table 16 gives the composition of sudan grass and of the silage made therefrom.

Table 16.

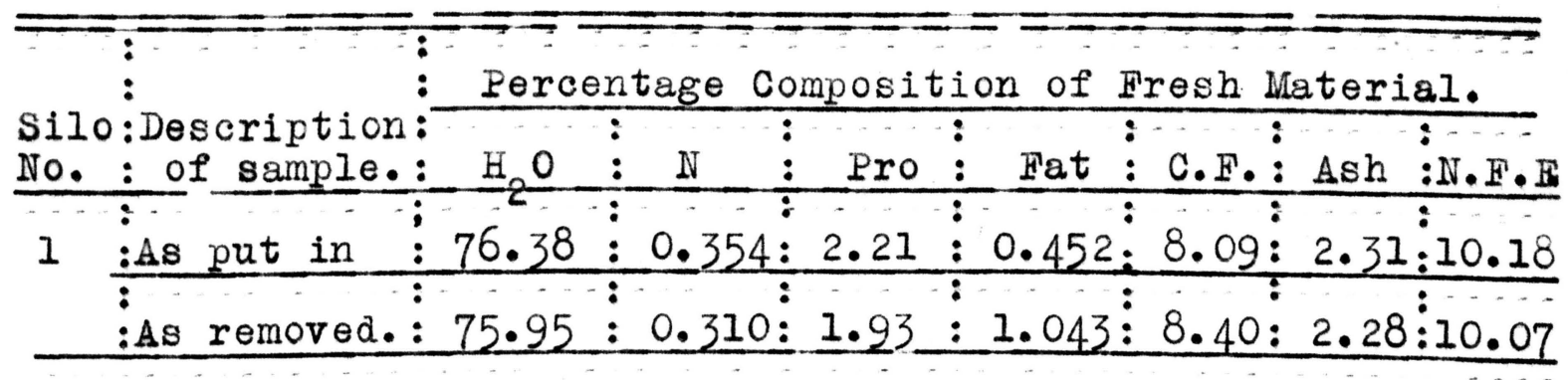


It will be noticed from the above table that there seems to be about a normal reduction in the per cent. of all the constituents.

Table 17 gives the weight of the fresh material and constituents put into the silo, the amount removed, and the percentage loss in silo No.l.

Table 17 .

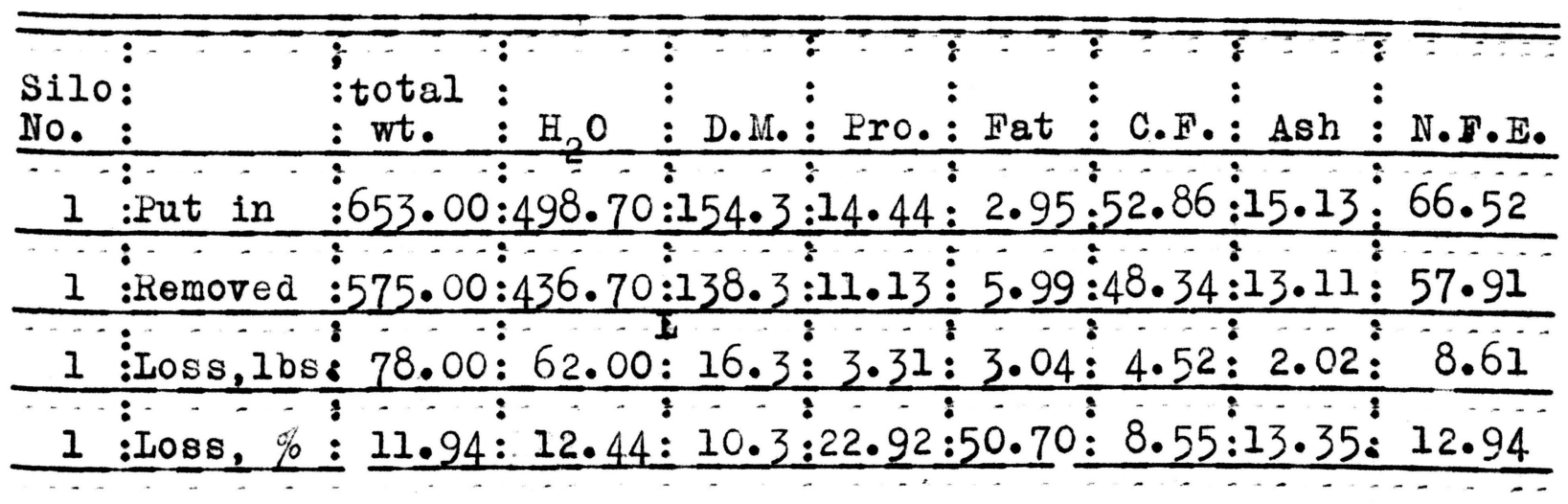

There was a normal loss in all of the constituents, except that of fat, which showed an increase of $50.7 \%$. This increase was due to either the conversion of some of the volatile acids into fats, or the conversion of some of the etherinsoluable substances into an ether-soluable form. 


\section{WEIGHT OF SIIAAGE PER CUBIC FOOT.}

\section{Object.}

The results so far obtained at this*Experiment station show wide variation in the weight of silage per cubic foot. It is not clear as yet what factors are responsible for this wide variation, but it is believed that the following are the most important ones.

1. The amount of moisture in the silage, which is influenced (1) by the maturity of the corn when cut and (2) by the water adoed, if any, at the time of filling the silo.

2. The pressure in the silo, which is influenced (1) by the packing done at the time of filling and (2) by the depth of the silage at which a cubic foot is taken.

3. The proportion of grain to fodder which is thought to be influenced (I) by the proportional yield of ears to stalks, and (2) by the manner of distribution of material in the silo when it is being filled.

4. The fineness of cutting.

The first two factors have been investigated by other experiment stations, as well as by the Missouri Experiment station during the last two jears.

\footnotetext{
*Magruder's Thesis for the degree of A.M. 1914. Oshel's
} Thesis for the degree of A.M., 1915. 
The object of the experiment now reported is to study :-

1. The effect of the proportion of grain to fodder on the weight of a cubic foot of silage.

2. The relation of the fineness of cutting to the weight of a cubic foot of silage.

3. To obtain more data on capacity in general.

\section{Plan of Experinent.}

Four baskets, six feet in diameter and five feet deep were made with one inch mesh poultry netting. The netting was doubled in each case so as to strengthen the baskets, and also to prevent the leaking out of any silage. In order to keep the baskets from interfering with the silage settling, it was thought best not to place any braces in the rim of the baskets. These baskets were designated as basket Nos. 1, 2, 3, and 4. The silos used in this experiment were the North and South Concrete Silos. The North Concrete Silo vas filled, as previously stated, September 22 to 24, with corn in the dent stage, cut $\frac{3}{4}$ inch in length. The South Concrete silo was filled September 26 to 29, with corn in the dough stage, cut inch in length. 
(1) Proportion of Grain to Fodder:- When the North Concrete silo was about one-third full, two baskets were put in.

Basket No. 1 was filled with corn cut $\frac{3}{4}$ inch after the ears had been removed.

Basket No. 2 was filled with corn cut $\frac{3}{4}$ inch to which the ears from No. I had been added.

(2) Fineness of Cutting:- When the silo was about two-thirds full, basket Nos. 3 and 4 were put in. Basket No. 3 was filled with corn cut 1 inch in length.

Basket No. 4 was filled with corn cut $1 \frac{1}{2}$ inch in length.

When these baskets were uncovered, about six inches of silage was removed from each and a cubic foot of silage carefully taken and weighed. A cubic foot was also taken from the silo at the same level with the baskets, to be used as a check.

Capacity in General:- To obtain further data along this line, weights per cubic foot were taken at different depths in the North and South Concrete Silos as the silage was fed out. The weights were taken as illustrated in the following Figure. 


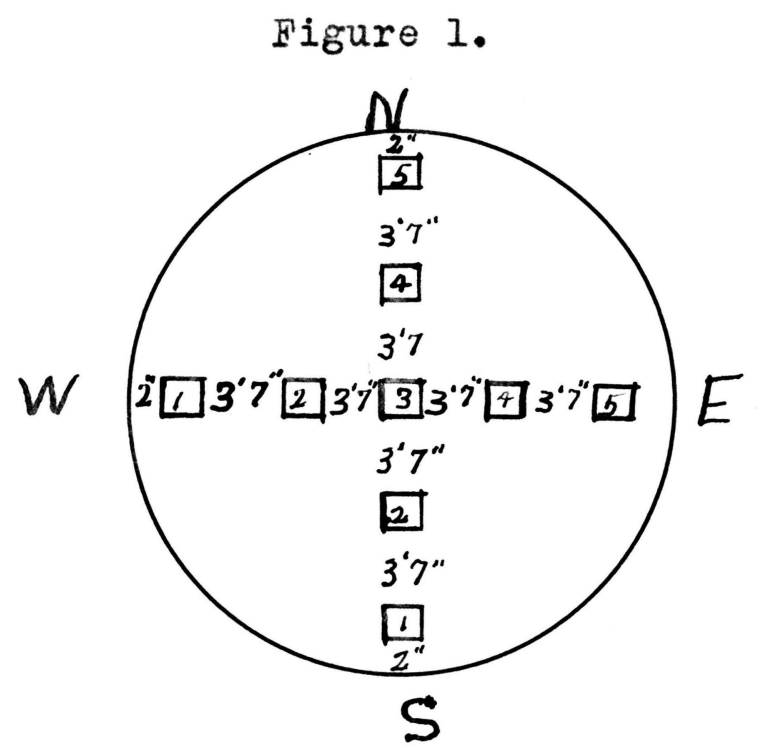

Thus an imaginary cross, East and West, and North and South was considered in the silo and five cubic feet taken along each line; Cubic foot No. I being at the West and South sides respectively. The third cubic foot being exactly in the center of the silo, served as the point of intersection of the cross. Samples were taken of cubic feet Nos. 1 and 2 each,time, and air-dry determination made.

\section{Discussion of Data.}

Proportion of Grain to Fodder:- Baskets Nos. 1 and 2 were uncovered January 15, 1916, after being in the silo 108 days. The baskets were crushed down, so that the total depth of the baskets had decreased from five feet, when put in the silo, to two and one-half 
when taken out. The silage in both baskets appeared to be normal to that in the silo but there was a wide variation in the weight per cubic foot, as shown in table No. 18.

Table 18.

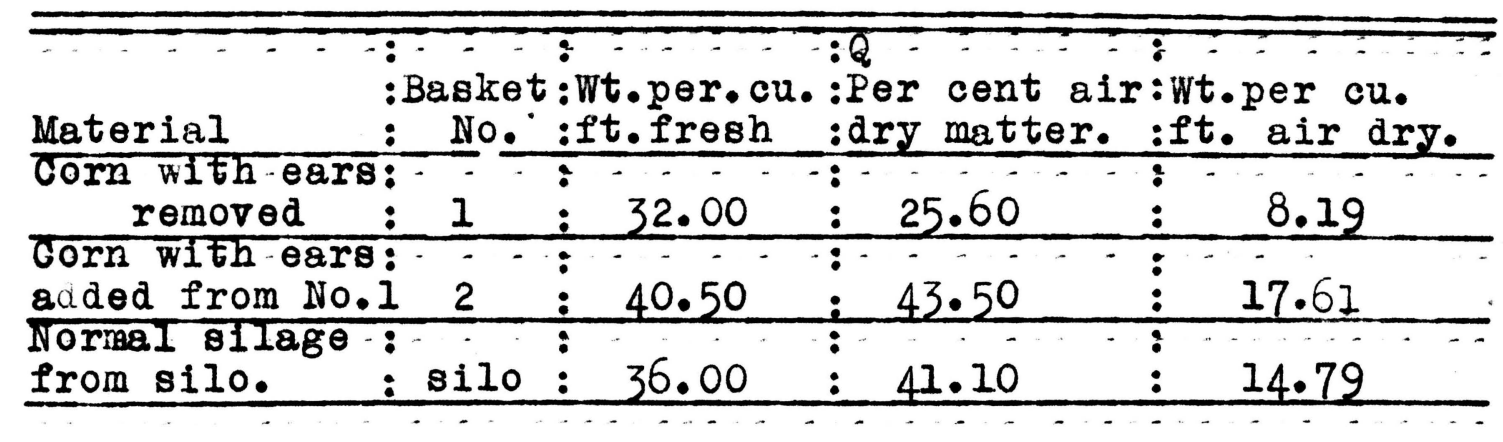

The weight of a cubic foot in Basket No. I, that was filled with corn from which the ears had been removed weighed 32.00 pounds, and a cubic foot from Basket No. 2 that was filled with corn to which ears from No. 1 had been added weighed 40.50 pounds. A cubic foot from the silo at the same level weighed 36.00 pounds. By removing the ears from the corn put in Basket No. I it reduced the weifht of a cubic foot of the silage made, 11.1 per cent from the normal weight of silage at that depth in the silo. By adding the ear from No. 1 to No. 2 it increased the weight 18.5 per cent. above the 
normal weight. These results are far more striking when we make the calculations on the basis of the air-ary matter. In this case there would be a reduction of 44.6 per cent in the case where the ears were removed and an increase of 16 per cent where the ears were added. Fineness of Cutting:- Baskets Nos. 3 and 4 were uncovered December 19, 1915, after being in the silo 88 days. These baskets were crushed fron five feet at the time of putting in the silo to three feet at the time of being uncovered. The silage in the baskets seemed to be norinal in every respect to that of the silo, as shown in table No. 19.

Table 19.

\begin{tabular}{|c|c|c|c|c|}
\hline Material & $\begin{array}{l}\text { : } \\
\text { :Baske } \\
\text { : No. }\end{array}$ & $\begin{array}{l}:: \\
: \text { Wt.per cu. } \\
\text { :ft. fresh. }\end{array}$ & $\begin{array}{l}\text {; } \\
\text {; Percent of: } \\
\text {; air-dry : matter: }\end{array}$ & $\begin{array}{l}\text { Wt. per cubic } \\
\text { ft. air dry• }\end{array}$ \\
\hline $\begin{array}{l}\text { Gorn cut } \\
1 \frac{1}{2} \text { inches. }\end{array}$ & 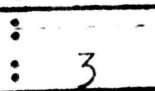 & 36.50 & 30.80 & 11.24 \\
\hline $\begin{array}{l}\text { Corn eut } \\
\frac{3}{4} \text { inch }\end{array}$ & $:$ & $36 \cdot 50$ & 40.40 & $14 \cdot 74$ \\
\hline $\begin{array}{l}\text { Normal to } \\
\text { silo cut } \frac{3}{4}\end{array}$ & sil & 36.50 & $: 40.40$ & $14 \cdot 74$ \\
\hline
\end{tabular}


A cubic foot of silage from basket No. 3 in which the corn was cut one and one-half inches, weighed 36.50 pounds, fresh, and 11.24 pounds air dry. A cubic foot from basket No. 4, in which the corn was cut threefourths inch, which is the same as that of the silo, weighed 36.50 pounds, fresh, and 14.74 pounds air dry. Although the weight of each cubic foot is the same in fresh substance there is a great difference in the weight per cubic foot air dry.

Assuming the weight of a cubic foot of silage to be equal to that of a cubic foot of water, the per cent of air in each cubic foot was calculated to be the same. Thus we can conclude that the greatest varying constituent of a cubic foot of silage, is the moisture. Capacity in General:- The most of these data were taken from the North Concrete silo, in which the silage was a little dry for normal silage. The weight per cubic foot at different depths at the wall and in the center, the per cent of air dfy matter and the weight per cubic foot, air dry are given in table No. 20.

The distance from the top of the silage, before opening, to the surface of the silage at the point where the weight was taken is given as the depth from the surtace of the silage. 
Table 20.

\begin{tabular}{|c|c|c|c|}
\hline $\begin{array}{l}\text { h from } \\
\text { of silage. }\end{array}$ & $\begin{array}{l}\vdots \\
\text { :Pounds per cu. } \\
\text { :ft. fresh. }\end{array}$ & $\begin{array}{l}\text { Per cent of } \\
\text { :air dry matter }\end{array}$ & $\begin{array}{l}\text { :Pounds per cu. } \\
\text { :ft. air dry. }\end{array}$ \\
\hline et $:$ Inches & : Wall: Center & $\vdots$ Wall ! Center & : Wall : C \\
\hline$:$ & $2.5 \div 27.0$ & $: 27.8 \div 34.0$ & $\therefore 6.25:$ \\
\hline 2 & $3.5: 28.5$ & $: 36.4 \div 34.9$ & $: 8.55:$ \\
\hline 6* $\vdots$ & $20.0: 28.0$ & $: 39.0: 35.0$ & $\div 7.80:$ \\
\hline $9 \vdots$ & $: 23.0: 30.25$ & $: 38.0: 28.0$ & $: 8.74: 8.47$ \\
\hline $13:$ & $29.0: 44.0$ & $: 38.8 \div 20.5$ & $: 11.25:$ \\
\hline $20 \div$ & $: 29.5: 32.5$ & $\because 40.5: 40.8$ & $: 11.94: 13.26$ \\
\hline $25:$ & $32.0 \div 36.5$ & $: 40.0: 39.0$ & $\vdots 12.80: 14.23$ \\
\hline $28: 5$ & $6.0: 40.0$ & $: 39.8: 38.5$ & $\because 14.32: 15.40$ \\
\hline $\mathrm{AV} \epsilon$ & $6.93 \div 33$ & $: 37.53: 33.71$ & $: 11.10: 11.23$ \\
\hline $\begin{array}{l}\text { cence betwee } \\
\text { ne highest a } \\
\text { bwest weight }\end{array}$ & $\begin{array}{l}\vdots 2.5 \% \\
\vdots \\
\end{array}$ & $\begin{array}{c}3 \underset{1}{3} .2 \% \\
\vdots \\
\end{array}$ & $\begin{array}{c}\vdots \\
\vdots \\
\vdots\end{array} \vdots .3 \%: 40.3 \%$ \\
\hline
\end{tabular}

* These cubic feet were taken in a layer of cowpea silage.

In table No. 20 giving the average of all weights it will be noticed that there is a wide variation between the weight of a cubic foot of the silage, fresh, at the wall and at the center of the silo. However, when the weight of air dry matter per cubic foot is considered it 
will be noticed that there is a difference of only .13 pounds. Again in the case of the fresh material it will be noticed that the weight per cubic foot varied in proportion to the per cent of moisture. The air-dry matter shows a gradual increase in weight per cubic foot, both at the wall and in the center of the silo, from the begirning at two feet, two inches from the top to the last cubic foot, twenty-eight feet, five inches from the top. These figures agree quite closely with those obtained by oshel in the South Concrete Silo, which are show in table No. 19 of his thesis.

In range of rariations in weights the difference is greater in the weight of air dry matter in a cubic foot than in a cubic foot of the fresh material. Although this great difference is evident, the variation in weight of the air dry substence in a eubic foot is much more constant than that of the fresh material.

Table No. 21 gives the weight per cubic foot at different depths in the North Concrete Silo. These weights were taken as illustrated in Fig. No. 1 and contains part of the data in table No. 3 .

Taking weights as inaicated in figure No. 1 , the following data were collected. 
Table 21.

:

Distance : Weight per cu.ft from West:Wt. per cubic ft.from from top : to East along Iine through: South to North along of silage:center of silo :line thro center of silo. reet:Inch:1st.:2nd.:3rd.:4th.: 5th. :Ist.:2nd.:3rd.: :4th.:5th. $5: 2: 23 \cdot 5: 25 \cdot 0: 28 \cdot 0: 29 \cdot 0: 32 \cdot 0 \quad: 23 \cdot 5: 24 \cdot 5: 28.5: 25 \cdot 0: 23 \cdot 5$ 6*:6 :20.0:24.0:27.0:28.0:34.0 - :34.0:34.0:27.0:34.0:35.5 $9: 4: 23 \cdot 0: 33 \cdot 2: 30.2: 22 \cdot 2: 27 \cdot 5: 23 \cdot 2: 30.2: 30.2: 22.7: 27 \cdot 7$ $13: 1: 29 \cdot 0: 41.0: 44 \cdot 0: 40.0: 31.5: 33 \cdot 0: 40.0: 44.0: 40.0: 35.0$ $20: 1: 29.5: 29 \cdot 0: 32.5: 32.5: 31.5: 32.0: 29.5: 32.5: 34.0: 30.7$ $25: 8: 32.0: 34 \cdot 5: 36.5: 34 \cdot 0 \pm 32.0: 32 \cdot 5: 34 \cdot 0: 36.5: 34 \cdot 0: 32.0$ $28: 5: 36.0: 38.0: 40.0: 38.0: 37.0: 36.0: 38.5: 40.0: 38.0: 36.0$

* These cubic feet were taken in a lajer of cowpea silage. It will be noticed that there is a great variation in the weight of a cubic foot taken two inches of the wall and one taken in the center of the silo. Although there is a variation between weights taken near the wall and at the center, as a whole there is a constant difference in weight of about six pounds between the wall and the center. Referring again to table No. 3 we find that the variation in the weight of a cubic foot in terms of air dry matter varies only .13 pounds. Thus we can conclude that in filling a silo, where a distributor is used, the lighter and 
coarser part of the material is blown out toward the wall of the silo. This is shown in table No. 4. It will be noticed from this table that near the top, or five feet two inches from the surface of the silage, the weight per cubic foot increases from 23.5 pounds at the west wall of the silo to 32 pounds per cubic foot at the East wall. This is accounted for in the fact that the distributor being very short when the silo is nearly full the material has to be blown over the silo, and necessarily the heavy grain fulls first. The distributor entered the silo in this case on the East side. The mean average of all cubic feet in table No. 3 shows the average weight of a cubic foot in the North Concrete silo to be 30.13 pounds, while the mean average of all cubic feet in table No. 4, taken from the same silo, shows the average weight of a eubic foot to be 32.25 pounds.

A study of our data in connection with the table on the capacity of silos compiled by King of the Wisconsin Experiment station, raises the question as to the accuracy of his figures for the weight of a cubic foot of silage at different depths. Our conclusion is that King's figures are too high due probably to the 
practice at that time of putting in corn much less mature than is done at present. The more mature corn gives a lower water content. As pointed out elsewhere in this experiment the air dry weight per cubic foot of silage is considerably more constant than the fresh weight. Table No. 5 is based upon the air dry weight per cubic foot, rather than weights of fresh silage.

\section{Wethod of Compiling Table.}

Referring to table No. 20 and taking the average of the figures in the first line of columns 3 and 4 as the average dry matter test, and an average of the figures in the first line of columns 5 and 6 , same table, as the weight of a cubic foot of silage, on dry matter basis, two feet, two inches from the top of the silage, it was calculated that for each foot of depth, the air dry matter increases .27 pounds, and for each per cent of dry matter the total dry matter increases .2l pounds.

Description of Table.

In this table the first column gives the depth from the top of the silage, the second and succeeding columns gives the weight per cubic foot of silage, in 
terms of air dry matter, when the per cent of air dry substance is as indicated at the top of each column. The weight of fresh material is reaily calculated from the air dry figure by dividing the air dry weight by the per cent of air dry substance. 
Table 22.

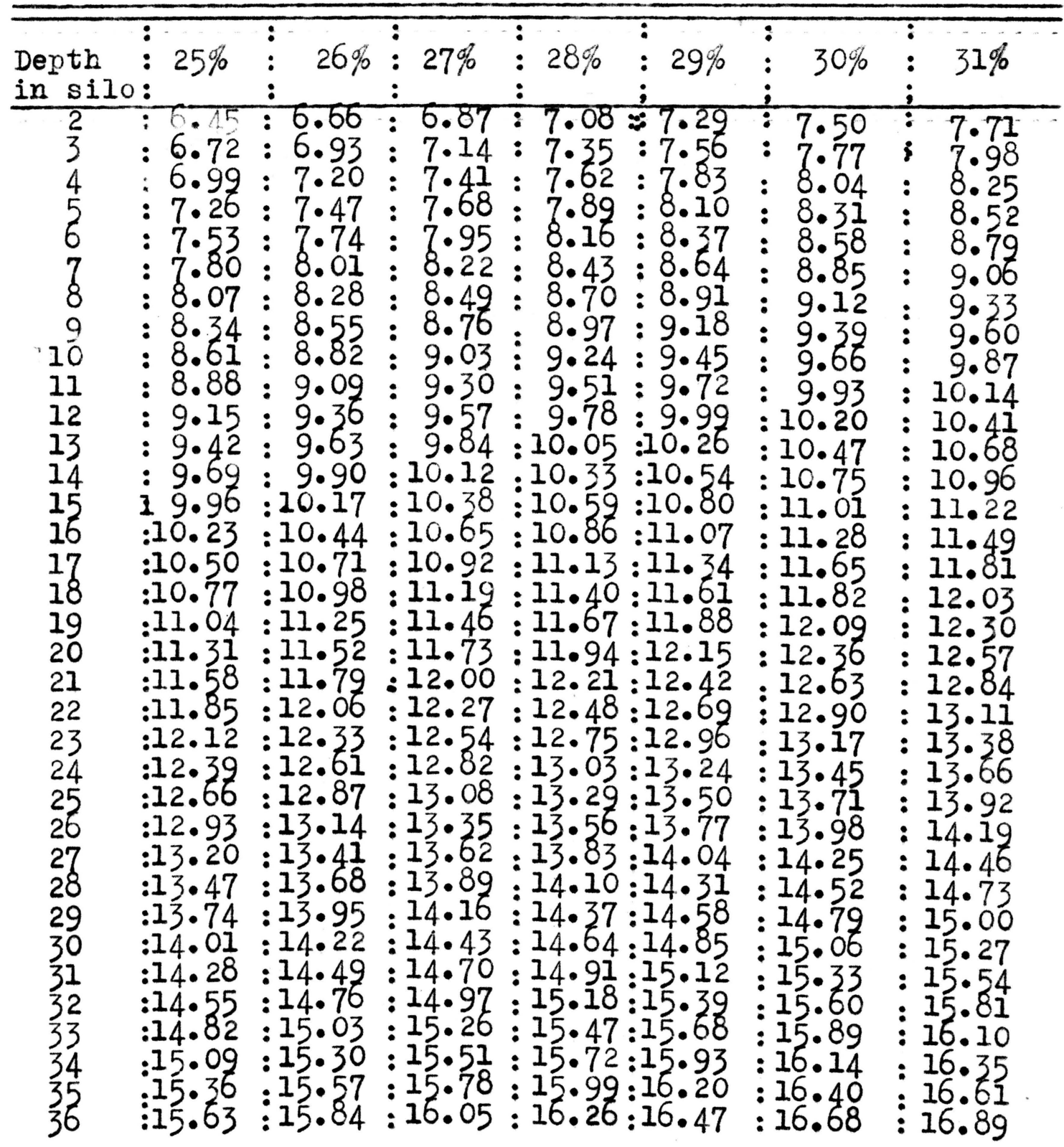

These figures are compiled for a silo 16 feet in diameter and it was calculated that for every foot over or under 16 feet a correction of . 162 pounds should be made. It should be added if the silo is larger and subtracted if smaller. This correction should be made before using the figure in the table. 


\section{INFLUENCE OF MOULD ON COIPOSITION OF SIIAGE.}

\section{object.}

The object of this experiment is to determine:

1. The effect of mould on the acidity of silage.

2. The effect of mould upon the composition of silage.

\section{Plan of Experiment.}

In this experiment in addition to the two experimental silos used a sample of 35 pounds of silage was taken from the North Concrete Silo. This sample was divided into three sub samples of 5000 grams each. Sub sample No. I was tested immediately for acid and complete analysis made. This sample served as a check on the other two.

Sub sample No. 2 was set in a mouse tight case at about 800F. and allowed to mold for three days, and then tested for acid and complete analysis run. Sub sample No. 3 was set under the same conditions as No. 2 and allowed to mold for six days, at which time it was tested for acid and complete analysis made. 
Corn taken from the same field and at the same stage of maturity was put into two experimental silos. The corn was thrown loose into silo No. I and no weights applied so as to allow the development of mould freely. The corn was thoroughly packed into silo No. 2 and 1500 pounds of weight applied to press out all the air possible. This silo was used as a check on silo No. 1.

\section{Discussion of Data.}

The two samples of 5000 grams each, taken from the large silo, showed considerable development of mould after standing two days. At the end of three days, when the first sample was tested for acid, it was found that nearly every piece of silage was covered with white mould, and the acid had been reduced from $1.87 \%$ to $0.23 \%$. At the end of six days, when the second sample was tested for acid, it was found that the mould had begun to cake. the silage. It had a very musty odor, and the color had changed from a dark straw shade to black. The acid had been reduced from $1.87 \%$ to $0.15 \%$.

When the two silos were open, 120 days after being filled, the silage in No. I had settled to nearly one half its original volume and had developed only $1.89 \%$ acid while the silage in silo No. 2 had developed $2.58 \%$ 
of acid. The silage in No. I had considerable mould, and came from the silo in cakes. It was estimated that about $50 \%$ of it was unfit for feeding purposes. The mould permeated the entire mass of silage, thus showing the presence of air throughtout the silo. The silage in silo No. 2 was in excellent condition, having a good silage odor, and a normal amount of acid. Silo No. 2 showed a loss of only $2.5 \%$ in total weight, while silo No. 1 showed a loss of $13.9 \%$. Table 23 shows the composition of three samples taken from the large silo, and of a sample taken from each of the experimental silos.

Table 23

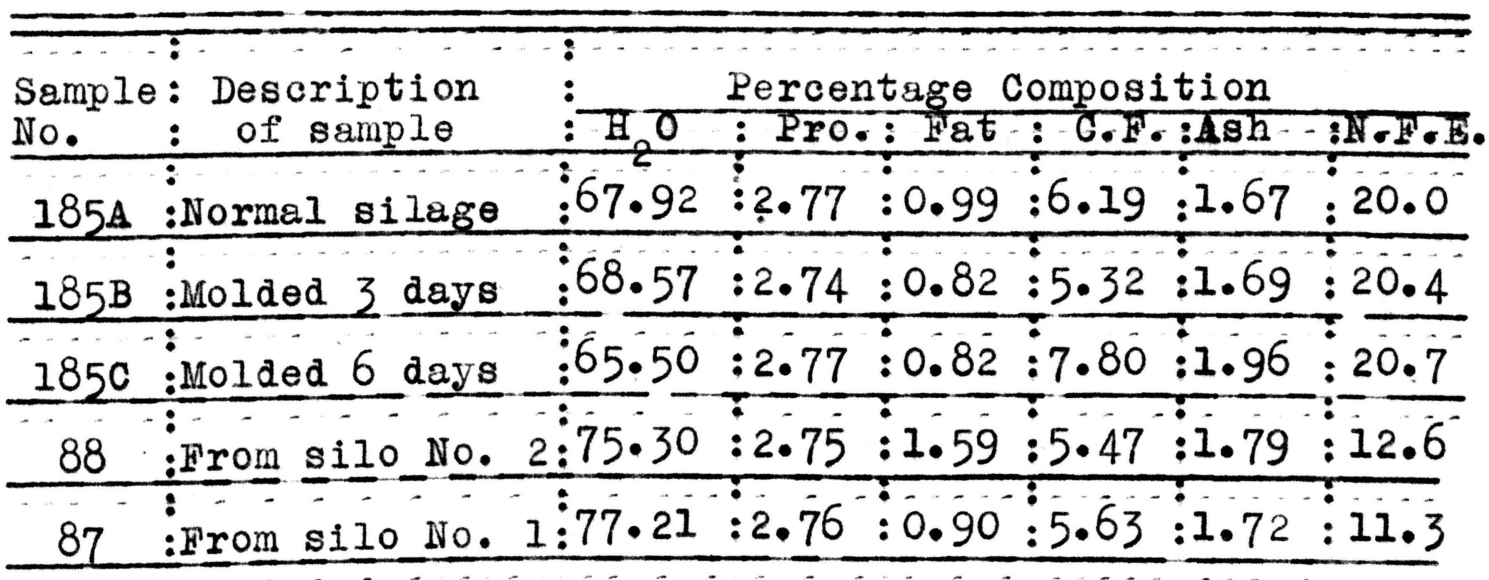

As indicated by the analysis there was a slight decrease in the constituents for the first three days, 
during wich the silage was allowed to mold. After this period there was a slight increase. The nirtogen and protein came back to normal, while the crude fiber, ash, and nitrogen-free extract went above the normal, or check sample, 185A. The fat did not reach the normal amount again, but it was greater than the amount present in the silage which was allowed to mold only three days. On the average there was very little change in the composition, and the writer is of the opinion that the extent of the change in composition is in proportion to the length of time the silage is allowed to mold. This is a shown in a comparison of sample 87 and 88 . It will be noticed that there was a great reduction in the amount of fat and nitrogen-free extract in Sample 87. However, the other constituents were affected very little.

Although there were very slight changes. in the composition of the silage during the molding periods, the following table shows that there was a decrease in all constituents for a few days and then a slight increase in the amount of crude fiber and ash. 
Table 24.

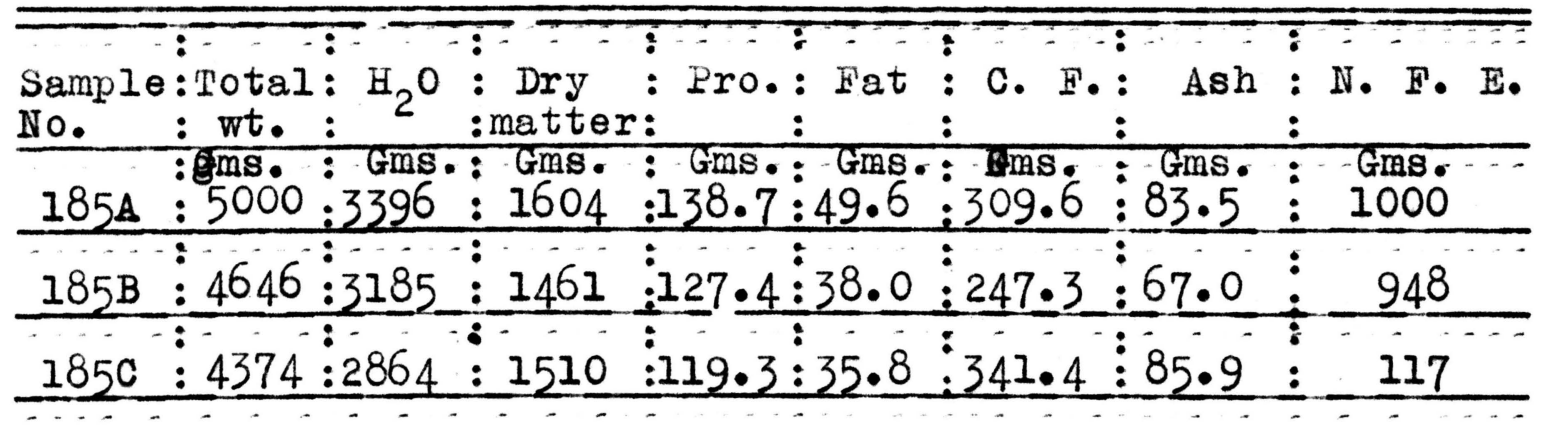

These results agree very closely with the losses in some of the experimental silos, in which silage molded considerably. There was an increase in crude fiber in every case where the silage molded in the silo. From these data it seems safe to conclude that: (I) Although moldy silage is not very good as a feed, the composition is not affected within a reasonable length of time. (2) Mould reduces the acidity of silage in direct proportion to the amount of mould developed. (3) Mould reduces, for a short period, the amount of each constituent in the silage without materially altering the composition. of the silage. There is an increase in crude fiber in moldy silage after a few days. 


\section{CONCLUSIONS.}

At the beginning of this paper, several leading questions were asked. The conclusions are given in the form of answers to there questions.

\section{Factors Influencing Acidity.}

1. The per cent of acid developed in silage is affected by the following factors: (1) By the nature of the silage crop; the one which contains the greatest amount of soluable carbohydrates has the highest per cent of acid. (2) By the per cent of moisture in the silage; the normal amount of acid being developed in silage containing from $65 \%$ to $75 \%$ moisture. (3) By the per cent of sugar in the silage crop when cut; the one having the greatest amount of sugar when cut, develops the highest per cent of acid.

2. Although the per cent of acid in silage is affected by the above three factors, the acid does not bear a direct relation to any one factor.

\section{Losses in The Silo.}

3. The losses occurring in the silo are in direct proportion to the extent of fermentation in the silage. 
4. There is a greater loss by field-curing of corn than by putting the green corn into the silo. 5. There is a greater loss in corn shocked in the field during December, January, and February than corn shocked in the field during October, November, and December.

6. There is a greater loss by feeding shock corn directly to cows than by siloing the corn and then feeding it.

7. The palatability of shock corn decreases in direct proportion to the length of time it is allowed to remain in the field.

\section{Iegumes for Silage.}

8. Good silage can be made from alfalfa containing from $60 \%$ to $65 \%$ of moisture when put into the silo; therefore green alfalfa should be allowed to dry in the sun three to six hours before being put into the silo.

9. Good silage can be made from mature or immature peas and oats, if they contain about $60 \%$ of moisture when put into the silo. Under ordinary conditions peas and oats contain from $70 \%$ to $85 \%$ of moisture when freshly cut. 
10. Where it is impossible to cure alfalfa on account of rainy weather, it is advisable to put it into the silo, after allowing it to dry out somewhat.

\section{Shock Corn Silage.}

11. Good silage can be made from shock corn when water is added in the ratio of $I: I$ and the silo filled very slowly•

12. There is no greater loss in silage made from shock corn than in silage made from green corn.

13. All of the sugar in shock corn is not completely reduced during silage formation.

14. There is a nomal amount of acid developed in silage made from shock corn.

\section{Other Crops for Silage.}

15. From the data available it is believed that good silage can be made from rye containing about $65 \%$ of moisture when put into the silo. Imnature rye contains from $70 \%$ to $85 \%$ of moisture when cut.

16. Good silage can be made from Sudan grass containing from $65 \%$ to $70 \%$ of moisture when put into the silo; therefore it is necessary to allow it to dry after cutting so as to 10 se from $10 \%$ to $20 \%$ of moisture before it is put into the silo. 
17. Silage made from sudan grass develops a normal amount of acid.

\section{Weight of Silage Per Cubic Foot.}

18. The weight of a cubic foot of silage at different depths in the silo is affected by several factors, three of which are: (I) The per cent of moisture in the silage. (2) The pressure in the silo. (3) The proportion of grain to fodder.

19. The weight of a cubic foot of silage in the center of the silo, at different depths, is correspondingly higher than a cubic foot at the wall.

20. The air-ary weight of a cubic foot of silage is more constant than the weight of the fresh material. 21. The average weight of a cubic foot of airdry material at the same level in the silo increases in direct proportion to the depth at which it is taken.

\section{Influence of Mould on Composition of Silage.}

22. Mould reduces, for a short period, the amount of each constituent in corn silage, after which there is an increase in the amount of crude fiber.

23. Mould reduces the acidity in silage in direct proportion to the length of time the silage is allowed to mold. 


\section{BIBIIOGRAPHY.}

1. "The Silo, its Construction and Filling"(loth Ann. Rpt. of the Agri. Exp. Station of Wisconsin, pp. 201.)

2. "The Silo and Silage". (Bul. No. 67, by J. Withycombe, Ore. Agri. Exp. Sta. )

3. "The Acidity of Corn Silage", by F. W. Morse, (14th Ann. Rpt. New Hampshire Agri. Exp. Sta., pp. 1151.

4. (Michigan Bul. 68.).

5. Art. in Chem. News, (70, (1894), pp. 273-275;-Babcock \& Russell).

6. Art. In Jour. of American Chem. Society, (34(1912), No. 11, pp. 1619-1625--Hart \& Willaman).

7. Art. Jour. Agri. Science, (1908,2,No. 4, pp. 395-410--

E. J. Russell of Rothamstead Exp. Sta.1.

8. "Causes Operative in Production of Silage"--Babcock \& Russell, (Wisconsin Agri. Exp. Sta. Rpt. of 1900, pp. 1231 .

9. "The Changes That Occur in the silo", (Vt. Agri. Exp. Sta. Ann. Rpt. 1889, pp. 96 ).

10. "Steamed Silage", (Ore. Agri. Exp. Sta. Rpt. 1905, pp. 531 .

11. "Shock Corn Silage",(Del. Exp. Sta. Rpt. 1903, pp. 38-41).

12. "Steamed Silage", (Ore. Agri. Exp. Sta. Rpt. 1903. pp. 34-38). 
13. "Causes Operative in the Formation of Silage"(Second Paper),(Wis. Agri. Exp. Sta. Rpt. 1901, pp, 177 ).

14. "Silo Temperatures Taken by Hectricity"(N.H. Agri. Exp. Sta. Rpt. 1900, Bul. 79, pp. 281 .

15. "When to Cut Corn for Silage",(N.H. Agri. Exp. Sta. Rpt. 1900, BuI. No. 31 .

16. "Ensilage in Dairy Farming", (Bul. No. 14, N. H. Agri. Exp. Sta.)

17. "Temperature Caused by Bacteria"(Ore. Agri. Exp. Sta. Rpt. 1902, pp. 68-69).

18. "Chemical Changes During Silage Formation", (Iowa Exp. Sta. Research Bul. No. 16, 1..

19. "Volatile Alphatic Acids of Corn Silage",(Research Bul. No. 7, Iowa Agri. Exp. Sta.).

20. "Lactic Acid in Corn Silage", (Research Bul. No. 10, Iowa Egri. Exp. Sta.).

21. "Sulfofication In Silos", (Research Bul. No. 18, Iowa Agri. Exp. Sta.)

22. Annales de Chimie et de Physique, 2, 289-324--Duclaux. -23. "Volatile Acids in Silage",(IIl. Agri. Exp. Sta. Bul. No. 7, pp. 190-193).

24. Stoklasa, Ernest and Chocensky; 2. Phys. Chem. 59,303. 25. "Silos and Silage", (Maryland Station, Third Annual Rpt. 1890, pp. 71$)$. 
26. "Silos \& Silage", (Nebr. Sta. Bul. No. 17, pp. 3-7).

27. "Silos \& Silage", (N. C. Sta. Bul. No. 80, Oct. I, $1891, \mathrm{pp} .181$.

28. "Comparison of Ensiling and Field Curing for Indian Corn";-H. P. Armsby, (Penn. Sta. Ann. Rpt. 1889, Part Two, pp. 113-137. Also Ann. Rpt. 1890, pp. 43123.).

29. "Shrinkage of Corn and Sorghum Silage in the Silo", (Ark. Sta. Third Ann. Rpt. 1890, pp. 5).

30. "Investigations as to the Changes in Feeding Stuffs by souring in the silo", by 0.Kellner et-al. (Landw. Vers. Stat., pp. 105-114).

31. "Feeding Silage vs. Dried Food", Utah Sta. Bul. 19, oct. 1892, pp. 11).

32. "Corn Silage for Making Beef", (Ontario College sta. Bul. 82, oct. 1892, pp. 81.

33. "A Comparison of Digestibility of Corn Silage and Corn stover in Feeding Rations and of Their effects upon the Consumption of Albuminoids"(Maryland Exp.sta. Rpt. for 1891, pp. 75-86).

34. "Corn Fodder vs. Corn Silage for Milch Cows", (Vt. Sta. Rpt. for 1891, pp. 75-86).

35. "The Relative Value of Corn Silage and Field Cured Fodder Corn for Milk and Butter Production"(Wis. Sta. Rpt. for 1891, pp. 49-601. 
36. "Feeding Silage to Lambs", (New York Cornell Sta.,Bul. No. 47, Dec. 1892, pp. 247-249).

37. "Rye vs.Silage" (Ala. Col. Sta. Bul. No. 46, June 1893. pp. 7.).

38. "Relative Value of Corn Silage and Fresh Corn Fodder", (Vt. Sta. Rpt. for 1892, pp. 154-155).

39. "Roots vs. Silage for Milk Production", (Mass. Hatch Sta. Rpt. for 1892, pp. 153).

40. "On the Econorny of Ensiling Indian Corn, Ears and All", (Wis. Sta. Rpt. 1892, pp. 53-71).

41. "Roots vs. Silage for Fattening Lambs", (Mich. Sta. Rpt. for 1892, pp. 247-251).

42. "Corn as a Silage Crop", (Maine Sta. Bul. 11, $2 d$ Series, pp. 4).

43. "Fnsiling Meadow Grass and Clover", (Norsk. Landmansblad, 13, 1894, pp. 260-262).

44. "Recent Experience in Fnsiling Grasses in Norway", (Tidskr. Norske Landbr., 1, (1894), pp. 198-217).

45. "Corn Silage and Straw for Making Beef", (Ont. Agri. Co1. and Expt1. Farm Rpt. 1893, pp. 118-121).

46. "The Conditions for the Production of Sweet \& Sour Silage" (Chem. News, 70(1894), No. 1828, pp. 273-275).

47. "Feeding silage vs. Dry Fodder", (Utah Sta. Rpt. 1893, pp. $11-201$. 
48. "Silos and Silage, Their History", (U. S. Dept. of Agri. Farmers' Bul. 32, pp. 30; Also Washington sta. Bul. 14, pp. 19.1.

49. "Silos and Silage"--F. H. King, (Wis. Sta. Rpt. 1893. pp. 201-227).

50. "Silos and Silo Building", (Penn. Bd. of Agri. Rpt. 1894, pp. 232-237).

51. "Cost of filling Silos, etc.",(Kan. Sta. Bul. 48, pp. $33-401$.

52. "Analysis of Silage from Stack Silos", (Rep. Ultuna Agri. Institute, 1894, pp. 75-77).

53. "Silage Analysis", (Del. Sta. Rpt. 1895, pp. 197-199; N. H. Sta. Rpt. 1894, pp. 118-120; also Tenn. Sta. Vol. IX, No. 3, pp. 51-164).

54. "Feeding Value of Beet Leaf Silage", (ztscr. Landw. Ver. Rheinpreussen, 13 (1896), No. 47, pp.393-395).

55. "Sunflower Heads and Blackeyed Peas as Silage Crops", (Maine Sta. Rpt. 1895, pp. 21-23 and 24-35). 56. "Composition and Digestibility of Corn Silage, Cowpea Silage, Soja Bean Silage and Corn Fodder", (IIl. sta. Bul. 43, pp. 181-208).

57. "Corn Silage for Milch Cows", (N. Y. Sta. Bul. 97, n ser. pp. 473-511).

58. "Small Lateral Pressure of Silage After Settling has Ceased", (Wis. Sta. Rpt. 1894, pp. 289-290). 
59. "The Necessary Loss in Dry Matter in Corn Silage", (wis. Sta. Rpt. 1895, pp. 273-278).

60. "Note on Silage", (Bul. Agri, et Commerce I(1896), No. I, p. 29-351.

61. "Corn Silage vs. Beets for Milch Cows",(Vt. Sta. Rpt. 1895, pp. 203-236; also "Corn Silage vs. Carrots", in same report.)

62. "Corn Silage vs. Corn Stover for Beef Cattle, (Ohio Sta. Bul. 60, pp. 561 .

63. "Robertson Mixture vs. Corn Silage for Milch Cows", (vt. Sta. Rpt. 1894, pp. 142-148).

64. "Silage Analysis", (Me. Sta. Rpt. 1896, pp. 28-29;

N. J. Sta. Rpt. 1896, pp. 127-133).

65. "Ensilage up to date" (Agri. Gaz. New South Wales, 9(1898), No. I, pp. 68-106).

66. "Cost and Feeding Value of the Dry Matter of Dried Corn Fodder and of Silage", (N. J. Sta. Bul. 122, pp. 16).

67. "Sunflower and Fnglish Horse Beans as Silage Crops", (Me. Sta. Rpt. 1896, pp. 32-34.).

68. "Corn Si age for Milch Cows", (N. Y. State Sta. Rpt. 1895, pp. 393-452).

69. "silage for Hogs", (Va. Sta. Bul. 68, pp. 101-105). 70. "The Construction of Silo and the Making and Handling of Silage. (Ioss in Silo) (Wis. Sta. Bul. 59, pp. 31). 
71. "Silage Making According to the Rahmstedt Mothod", (Iandmannen, 8(1897), No. 38, pp. 540-542).

72. "The Influence of Silage Odors in the Air on Milk", (Wis. Bul. 59, pp. 25-28).

73. "Ensilage or the Preservation of Green Fodder", (Cape Town; W. A. Richardson and Sons, 1893, pp. 34 ).

74. "Silage Presses", (Landtmannen, 8(1897), No. 35, pp. 93-494).

75. "Feeding Trials with Silage and Potatoes for Milch Cows", (Vt. Sta. Rpt. 1896-97, pp. 169-174, 218-220).

76. "Cost and Building of Silos", (S. D. Sta. Bul. 51, pp. 20-32).

77. "Cheap Silos in Virginia", (Va. Sta. Bul. 70, pp. 115-119).

78. "Silage and Silage Crops", (Wich. Sta. Rpt. 1896, pp. 107-109).

79. "Silage Analysis", (Conn. Storrs.Sta. Rpt. 1897, pp. 189-198; Ind. Sta. Rpt. 1897, pp. 16-24 N. J. Sta. 1897, pp. 76-77).

80. "Silage and Silos", (N. Y. State Sta. Rpt. 1896, pp. $641-656)$.

-81. "Cowpea Ensilage". (Country Gentiemen, 64 (1899), No. 2403. pp. 124-125).

82. "Digestibility of Silage", (Me. Sta. Rpt. 1897, pp. $141-1581$. 
83. "Silos and Ensilage", (Pacific Tree and Vine, 14(1898), No. 47, pp. 142-1431.

84. "Making and Feeding Stack Silage", (Ima dmannen, 8(1897), No. 40, pp. 574-579).

85. "Analysis of Sugar-beet Pulp Silage and Barley Silage", (Cal. Sta. Rpt. 1895-97, pp. 112-116).

86. "Silege vs. Mixed Feeds for Butter Production", (ont. Agri. Col. and Exp. Sta. Rpt. 1897, pp. 59-68).

87. "Silage Analysis", (Conn. Storrs Sta. Rpt. 1898, pp. 229-242; Me. Sta. Rpt. 1898, pp. 75-78; N. J. Sta. Rpt. 1898, pp. 101-102).

88. "Digestibility of Silage", (Mass. Hatch Sta. Rpt. 1898, pp. 43.1 .

89. "Silage for Horses", (Va. Sta. Bul. 80, pp. 97-98).

90. Silage for Horses and Hogs", (U. S. Dept. of Agri. Farmers' Bul. 103, pp. 32 ).

91. "The Wraking of Silage", (Fuhling's Landw. Ztg., 48(1899), No, 20, pp. 745-749).

92. "Stack Silage", (New Zealand Dept. of Agri., Rpt. 1899, pp. 168-169).

93. "Construction of Stave Silos", (N. Y. Cornell sta. Bul. 167, pp. 473-488).

99. "Digestibility and Fuel Value of Silage", (Me. Sta. Bul. 67. pp. 133-170). 
95. "Silage Analysis",(Conn. Storrs. Sta. Rpt. 1899, pp. 209-215; Miss. Sta. Rpt. 1899, p. 39-41).

96. "Stave Silos", (Canada Cent. Exp. Farm Bul. 35, pp. 11).

97. "Management of Ensilage Crops", (Univ. Tenn. Record, 4(1901), No. 1, pp. 68-75).

98. "Comparison of Corm Silage, Sugar Beets, and Mangels and Foods for Milh Cows", (Penn. State Rpt. 1899, pp. $111-123)$.

99. "The Influence of Carbon bisulphid and Common Salt on the Iosses of Nutrients and the Character of Fermentation of Ensiled Fodaer", (Zap. Novo-Alexandri Inst. Selsk. Khoz. i Lyesov., 1899, pp. 39; Abs. in Selsk. Khoz. i Iyesov., $196(1900)$ Feb. , pp. 470-471).

100. "Making and Storing Silage", (U. S. Dept. of Agri. Office of Exp. Sta. Bul. 82, pp. 55.).

101. "Corn Silage, Sugar beets and Mangels, a Comparison of their field and Cost of Production", (Penn. Sta. Rpt. 1899. pp. 104-111).

102. "The Relation between Temperature and Fermentation in the Ensiling of Green Fodder", (Annales de la science Agronomique, 1900, II, No. 1, pp. 1-32).

103. "Silo Construction and Silage", (S. C. Sta. Bul. 5l, pp. $15 \%$.

104. "Silage and the Construction of Modern Silos"(Loss in silos), (Wis. Sta. Bul. 83, pp. 68). 
105. "Analys is of Liquor Obtained from Silo Press", (New Zealand Dept'. Agri. Rpt., 1900, pp. 127-137).

106. "Alfalfa Silage",(U. S. Dept'. of Agri. Farmers' Bul. 124, pp. 32 ).

107. "The silo and Silage",(Acidity in silage)(Ore. Sta. Bul. 67, pp. 87-110).

108. "Causes Operative in the Production of Silage", (Wis. Sta. Rpt. 1900, pp. 123-141).

109. "Silage Analysis", (Conn. Storrs Sta. Rpt. 1900, pp. 82-95d.

110. "Shrinkage of Silage", (Mich. Sta. Bul. 191, pp. 159-172).

111. "Unavoidable Losses in Silage",(Wis. Sta. Rpt. 1900,pp• 189-196).

112. "Causes Operative in the Formation of Silage",(Wis. Sta. Rpt. 1901, pp. 177-1841.

113. "Influence of Close Packing of corn in the silo on the Unaroidable Losses in Making Silage", (Wis. Sta. Rpt. 1901, pp. 200-209).

114. "Losses in Preparation of Silage", (U. S. Deft.t. of Agri. Farmers' Bul. 133, pp. 32 ).

115. "Silos and Silage" by H. H. Dean, (Ont. Dairymen's Asocs. Rpts. 1901, pp. 176 ).

116. "Silos and Silage", (U. S. Dept. of Agri. Farmers' Bul.32, rev. ed. pp. 30 ).

117. "Silage Studies", (N.H. Sta. Bul. 92, pp. 49-62). 
118. "Silage Analysis", (Conn. Storrs Sta. Rpt. 1901, pp. $165-1781$.

119. "Acidity of Com Silage", (N. H. Sta. Bul. 96, pp. $115-117)$.

120. "The Modern Silo", (Ind. Sta. Bul. 91, pp. 83-106).

121. "Silos for Grain", (Jour. Agri. Prat. n. Ser. 2(1901), Nos. 32, pp. 170-174, figs. 5; 33, pp. 210-214, figs.5; 36, pp. 310-312, figs.11)

122. "The Growth of Waize for Insilage",(Jour. Southeast Agri. Col. Wye. 1903, No. 12, pp. 40-47).

123. "Crops for the Silo", (Tenn. Sta. Bul. Vol. XVII, No. 1).

124. "Experiments with Feeding steers and Lambs", (Ont. Agri.Col. and Exp. Farm Rpt. pp. 69-71 and 133-1481.

125. "Some Experiments with Fnsiling of Grass and Beets", (Jour. Soc. Cent. Agri. Belg., 50(1903), Nos. 5, pp. 200-201; 6, pp. 229-2301.

126. "Modern Silage Methods",(Salem, Ohio, The Silver Mfg. Co. 1903, pp. 199l.

127. "The Modern Silo", (Jour. Dep't. of Agri. Victoria, 2(1903), No. 4, pp. 320-331\} Dep't. Agri. Victoria. Bul. 8, pp. 14 ).

128. "Stack Ensilage", (Council Agri. Tasmania, Bul. 7, pp. 8).

129. "The Octaginal Silo", (Del. Sta. Rpt. 1902, pp. 30-35d.

130. "The Construction of Silos", (N. D. Fariners' Inst. Ann. 1903, pp. 192 ). 
131. "Silage Analysis", (Ont. Agri. Col. Exp. Farm, Bul. 138, pp. 32.1.

132. "The Effect of Silage on the Acidity of Milkn, (Conn. Storrs Sta. Rpt. 1904, pp. 150-151).

133. "Silage Experiments", (Kan. Sta. Bul. 123, pp. 226-249).

134. "Feeding Silage to Milch Cows", (Ore. Sta. Rpt. 1903, pp. 44-45).

135. "Causes of Silage Fermentation", (Wis. Sta. Rpt. 1903. pp. 243-249).

136. "Forage vs. Silage for Dairy Cattle", (N.J. Sta. Rpt. 1903, pp. 363-364).

137. "Silage v8. Grain for Dairy Cows", (Ohio sta. Bul. 155, pp. 63-80).

138. "soy Bean silage a a Food for Dairy Cows", (wis.sta. Rpt. 1904, pp. 67-74).

139. "Pit silos", (Col. Sta. Bul. 88, pp. 19-24).

140. "Silage for Hog Feeding",(Ore. Sta. Bul. 80, pp.19).

141. Making and Handring Silage", (Wis. Ste. Rpt. 1903, pp. 346-353).

142. "Boy Bean and Corn Silage", (Mo. Sta. Bul. 106, pp. 113-121).

143. "Silo Construction", (Wis. Sta. Bul. 125, pp. 92).

144. Modern Silage Methods", (Jour. Dep't. Agri. viotoria, 3(1905), No. 1, pp. 29-40). 
145. "Crops for the Silo, Cost of Filling, and Effect of Silage on the Flavor of the Milkn!(IIl.Sta. Bul. 101, pp. 627-644, Figs. 71.

146. "Silage for Dairy Cows",(U. S. Dep't. of Agri. Farmers' Bul. 222, pp. 32, Fig. 1j.

147. "Losses in Silage", (Canada Exp. Farm Rpts. 1904, pp. 453-466).

148. "Syllabus of Illustrated Iectures on Silage and Silo Construction for the South", (U. S. Dep't. of Agri. Office. Exp. Stas., Farmers' Inst. Lecture 5, pp. 31 ).

149. "Analysis of Rape and Corm Silage", (Canada Expt. Farms Rpts. 1904, pp. 166-182).

150. "Silo Construction (Article), (Bul. Maine Dep't. of Agri. 4(1905), No. 3, pp. 77-99).

151. "Forage Crops and the Silo", (Fla. Sta. Bul. 78, pp. 285-311, Figs. 8).

152. "Construction of silos",(IIl. Sta. Bul. 102, pp. 41, Figs. 34.).

153. "Silage Analysis", (Wash. Sta. Bul. 72, pp. 27, dgms. 1$)$.

154. "Bacteriological Studies of Ensiled Forage", (Ann. Ist. Agri. (Milan), 6(1901-1905), pp. 105-122, pls. 2). 
155. "Calculated Loss from the Heating of Moistened Corm Fodder", (Del. Sta. Rpt. 1903, pp. 40-41).

156. "Cost of Producing Silage Crops",(N. J. Sta. Rpt. 1905, pp. 349-376,P1s. 10).

157. "Clover and Grasses for Silage", (Canada Expt. Farms Rpts. 1905, pp. 364-3801. 158. Article on "The Effects of Silage on Milk", (U. S. Dep't. of Agri. Farmers' Bul. 267, pp. 32).

159. "msilage for Horwes", (Nat'l. Agri. Jour. and Min. Rec. 9(1906), No. 5, pp. 485-488).

160. "Silage Analysis", (Conn. State Sta. Rpt. 1906, pt. 3, pp. 169-218).

161. "Cost Notes on a Reinforced-Concrete Silo", (Fing. Rec. 54(1906), No. 22, pp. 607, Figs.2).

162. "Cost of Filling Silo", (U. S. Dep't. of Agri. Office Exp. Sta. Bul. 173, pp. 48, pls. 4, Fig. 24).

163. "The Number and Distribution of silos in Wisconsin.", (wis. Sta. Rpt. 1905, pp. 363-366. Fig. 1).

164. "Acidity as affected by steaming silage", (ore. sta. Rpt. 1905, pp. 53-57).

165. "Silage Analysis", (N. H. Sta. Bul. 129, pp.239-242). 
166. "Feeding Silage to Dairy Cows", (N. H. Sta. Bul. 129, pp. 255-257).

167. "Finishing Beef on Silage", (Va. Sta. Bul. 173, pp. 95-122. Figs. 5).

168. Article on "Silage from Frosted Corn", (U. S. Dep't. of Agri. Farmers' Bul. 309, pp. 32 ). 169. Article on "Silage Making", (U. S. Dep't. of Agri. Farmers' Bul. 316, pp. 32, Figs. 41. 170. "Silo and Silage",(S. C. Sta. Bul. 128, pp. 24, Fig. 1).

171. "Cost of Filling Silo", (U. S. Dep't. of Agri. Farme rs' Bul. 292, pp. 15, Figs. 3 ).

172. "Maize as a Fodder and Silage Crop", (Jour. Bd. Agri. (Iondon) 14 (1907), No. 1, pp. 14-22).

173. "Analysis of Ensilage from Biggenden state Farm", (Queensland Agri. Jour., 18, (1907). No. 4, pp. 1991 .

174. "Silage Analysis", (N. J. Rpt. 1906, pp. 37; Ann. Rpt. Dep't. Agri. and Stock(queensland) No. 3-4, pp. 215-218; Hawaii sta. Rpt. 1907, pp. 63-66; Jour. Agri. Sci. 2(1908), No. 4, pp. 382-391; Tenn. Sta. Bul. 80, pp. 31-50; Jour. Southeast Agri. Col. Wye, 1907, No. 16, pp. 201-214; Ore. sta. Bul. 102, pp. 3-29; Conn. State Sta. Rpt. 
1907-8, Pt. 10, pp. 717-762; s. C. Sta. Rpt. 1909, pp. 24,25; Ann. Rpt. Ont. Agri. Col. and Expt. Farm, 35, (1909), pp. 61-66; Jour. Southeast Agri. Col. Wye, 1908, No. 17, pp. 434-441; Missouri sta. Res. Bul. No. 2, pp. 107-147; Penn. Sta. Bul. 102, pp. 3-16; Ann. Rpt. Ont. Agri. Col. and Expt. Farm, 36, (1910), pp. 77-79)

175. "Cherical Changes Taking Place During the Ensilage of Maize", (Jour. Agri. Sci. 2(1908), No. 4, pp. 395-410).

176. "Chemistry of Silage", (Nature-Study Rev. 6(1910) No. 1, pp. 10-16).

177. "Cost of silage Crops", (N. J. Stas. Rpt. 1906 pp. 270-297, pls. 9; also Rpt. 1907, pp. 55-79; Rpt. 1908, pp. 25-41; Rpt. 1909, pp. 43-55; Hoard's Dairyman, 42(1911), No. 28, pp. 656)

178. "Silos and Silage in Maryland", (Ma. Sta. Bul. 129, pp. 78 ).

179. "Silos and Silage", (Dep't. of Agri. N. Sa Wales, Farmers' Bul. 6, pp. 79, Pls. 3, Figs. 76 ). 180. "Digestibility of Silage", (Ann. Rpt. Ont. Agri. Col. and Expt. Farm, 32(1906), pp. 74-87). 181. "Digestibility of Silage", (Mass. Sta. Rpt. 1906, pp. 96-156; also s. D. Sta. Bul. 114, pp. $525-554)$. 
182. "Feeding Value", (Penn. Sta. Bul. 83, pp. 16) (Ohio Sta. Bul. 193, pp. 149-166) (N. Y. State Sta. Rpt, 1907, Pt. 3, pp. 66-109) (Ind. sta. Bul. 129, pp. 233-278) (N. Y. Cornell Sta. Bul. 268, pp. 443-487). 183. "Some Observations on the Fermentation of silage", (Science n. Ser., 31,(1910) No. 797, pp. 547-548).

184. "Fertilizing Value", (Penn. State Bul. 102, pp.3-16) (N. H. Sta. Bul. 129, pp. 248) (N. J. Sta. Bul. 204, pp. 281 .

185. "Cotton seed Meal and Corn Silage as a Ration for Dairy Cows", (s. C. Sta. Bul. 131, pp. II) (N. J. Sta. Rpt. 1907, pp. 39-55) (U. S. Dep't. of Agri. Farmers' Bul. 320, pp. 32) (Miss. Sta. Bul. 111, pp. 6)

186. "Silage vs. Hulls and Merl", (Miss. Sta. Bul. 112, pp. 2-8) (Tenn. Sta. Bul. 80, pp. 31-50).

187. "Silage in The Dairy Ration", (s. C. Sta. Rpt, 190, pp. 26-29).

188. "Roots and Corn Silage for Fattening Lambs", (Iowa sta. Bul. 110, pp. 451-474).

189. "Corn Silage for Winter Feeding Fwes and Young Lambs", (Ind. Sta. Bul. 147, pp. 61l-628).

190. "Silage for Finishing Beef Cattle" (Va. Sta. Bul, 173. pp. 95-122).

191. "Silage for Steer Feeding", (Penn. Sta. Rpt. 1909, pp. $146-153)$ 
192. "Utilization of Silage as Refuse", (U. S. Dep't. of Agri. Bureau of Plant Industry, Cir. 45, pp. 12.).

193. "Acidifying Silage Beet Chips by Means of Lactic Acid Culture", (Amer. Sugar Industry and Beet Sugar Gaz. 12(1910), No. 2, pp. 39 ).

194. "Feeding Silage Made from Frosted and Frozen Corn", (vt. Sta. Rpt. 1906, pp. 302-336, 356-384).

195. "Analysis of Green Silage", Wis. Sta. Cir. Information, 22, pp. 109).

196. "Notes on Silage", (S. C. Sta. Bul. 128, pp. 24) (Alaska Sta. Rpt. 1910, pp. 63-65,P1.1)

197. "Monascus purpureus in silage", (Micologia, 2(1910), No. 3, pp. 99-108,P1s.2, Figs. 2 ).

198. "Monascus purpureus in Silage Cause of CerebroSpinal Meningitis", (Amer. Vet. Rev. 38(1911), No. 4, pp. 473-488, Figs. 24$)$.

199. "Ensilage Poisoning in Horses", (Missouri Valley Vet. Bul. 4(1909), No. 7, pp. 30-32).

200. "Silo Construction", (Va. Sta. Bul. 182, pp. 3-23, Figs. 13).

201. "Dep't. of Agri. N.S. Wales, Farmers' Bul. 6, pp. 79, PIs. 3, Figs. 76 ).

202. "Experiments with Alfalfa Hay and Alfalfa Silage", (Nevada sta. Bul. 72, pp. 37-40). 
203. "Silo Construction", (U. S. Dep't. of Agri. Farmers' Bu1. 405, pp. 32, Figs. 13).

204. "Concrete Silos". (Concrete Rev. 3,(1909), No. 11 and 12, pp. 67, Figs. 37) lalso(Washington D. C. 1909, pp. 68, Figs. 37 ).

205. "Cement Silos in Michigan", Mich. Sta. Bul. 255. pp. 63-92, Figs. 29).

206. "Modern Silo Construction", (Iowa Sta. Bul. 100, pp. 94-150, Figs. 45).

207. "Construction and Filling of Silos", (Washington Sta. Popular Bul. 10, pp. 8, Figs. 11).

208. "Silo Construction", (U. S. Dep't. of Agri, Farmers' Bui. 353, pp. 32, Figs. 14).

209. "Silo Construction", (Va. Sta. Bul. 182, pp. 3-23, Figs. 13).

210. "Hollow Clay Tile or Iowa Silo", (Iowa sta. Bul. 161, pp. 3-20, Figs. 21.

211. "Frozen Silage for Cattle", (Ind. Sta. Bul. 153, pp. 3-67).

212. "Ensilage Methods, Bavaria", (Daily Cons, and Trade Rpts. (U.S.), 15(1912), No. 14, pp. 282-283).

213. "Investigations on the Changes in the Nutritive Value of Feeds by Fermentation in a Silo, and the Accompanying Loss in the Silo", (Landw. Vers. stat. 74, 1911, No. 3-5, pp. 263-342) (Abs. in Zentbl. Agri. Chem. 40(1911), No. 9, pp. 621-627) 
214. "Stack Silage", (Queensland Agri. Jour., 27(1911), No. 5, pp. 218-219).

215. "Silage and Silo Construction", (Agri. Ed. (Kan, Agri. Col. ), 2(1910), No. 4, pp. 72, Figs. 18).

216. "Soiling and Summer Silage", (Amer. Cult., 73(1911) No. 49, pp. 1-3, Fig. 1).

217. "Silage and Concrete, Size, etc.",(Wyo. Farmers' Bul. 1, 1911, No. 5, pp. 69-72, Figs. 21.

218. "Construction of Concrete and Clay pile silo", (Engin. and Contract, $37(1912)$, No. 10, pp. 256-257)

219. "Mexican Silos", (Hoard's Dairyman, 42(1911), No. 43, pp. 1321, Figs. 3).

220. "Concrete Silo", (A Hand Book) (Chicago and Pittsburg, lst. Ed. 1911, pp. 88, Figs. 74).

221. "Types of Silos", (Okla. Sta. Cir. 15, pp. 3-4, Fig. 16j.

222. "Article on Plastered Silos", (U. S. Dep't. of Agri. Farmers' Bul. 469, pp. 24, Figs. 9 ).

223. "Silage Analysis", (Wis. Sta. Cir. Information 30, pp. 98 )

224. "General Review of Silage Investigation", (R. Lab. Chim. Agr. Udine, Ric. Sper. e. Attiv, Spiegata, 3(1909-10), pp. 55-90). 
225. "Fnsilage of Fodder, Roots and Beet Pulps"--Use of Lactic Ferments, (Jour. Agri. Prat.; r. Ser. 20(1911), Nos. 42, pp. 488-490; 44, pp. 549550; Abs. in Internat. Inst. of Agri. (Rome) Bul. Bur. Agri. Intel. and Plant Diseases, 3(1912), No. 1, pp. 195-200).

226. "Silage Analysis", Ann. Rpt. Ont. Agri. Col, and Exp. Farm, 37 (1911), pp. 69-71).

227. "Silage Fermentations", (Conn. Storrs Sta. Bul. 70, pp. 40, Figs. 31 .

228. "Silage from Turnip Leaves", (Norsk. Landmandsblad, 31 (1912), No. 34, pp. 451-452).

229. "Notes on Silage in Porto Rico", (Porto Rico sta. Rpt. 1911, pp. 40-44).

230. "Silos and Silage", (Washington Sta. Popular Bul, 46, pp. 4$)$.

231. "Corn Silage and Roots for Steers", (S. D. Sta. Bul. 137, pp. 354-367, Figs. 11).

232. "The Use of Silage", (Bul. Office of Gourt. Gen. Algeria, 1911, No. 15, Sup. pp. 251-315, Figs. $14)$.

233. "Cement silo Construction", (Cement and Fng. News, 24, 1912, No. 4, pp. 123-125) also (Ag. Ed. (Kan. Agri. Col), 4(1912), No. 6, pp. 79, Figs. 29).

234. "Cement stucco Silos", (South. Agr. 42,(1912), No. 13, pp. 10-11). 
235. "Soilage vs. Silage for Dairy Cows",(Wis. Sta. Bul. 218).

236. "The Silo for Missouri Farmers",(Missouri Sta. Bul. 103, pp. 293-3051.

237. "Silage Analysis", (Ann..Rpt. Dep't. Agri. and Stock, (Queensland), 1911-12, pp. 74-77).

238. "Cotton Seed Meal and Silage vs. Cotton Seed Meal and Hulls for Fattening Cattle", (Texas Sta. Bul. 153, pp. 3-14).

239. "Value of Corn Silage for Beef Production", (Nebr. Sta. Bul. 132, pp. 52, Figs. 61 .

240. "Silage for Steers", (Penn. Sta. Bul. 118, pp. 3-20, Figs. 8) also (s. c. Sta. Bul. 169, pp. $3-16)$.

241. "Crops of Alaska for Silage", (Alaska stas. Rpt. 1911, pp. 47-53, 59-61).

242. "Cost of Producing Silage in Alabama", (Ala. Col. sta. Circ. 18, pp. 97-1281.

243. "Notes on Silage", (Miss. Sta. Bul. 158, pp. 4-7). 244. "The Action of Monocalcium Phosphate on Fermentation in Silage", (Atti. R. Accad. Iincei, Rend. c1. Sci. Fis. Mat. e, Nat. 5, ser., 21,(1912), II. No. 1, pp. 108-112).

245. "Concrete Silo Construction", (Wis. Sta. Bul. 214. pp. 3-31, Figs. 18). 
246. "The Volatile Alphatic Acids of Corn Silage", (Jour. Amer. Chem. Soc.,35(1913), No. 1, pp. 90-93) also (Iowa. Sta. Kes. Bul. No. 7, pp. $5-321$.

247. Volatile Fatty Acids and Alcohols in Corn Silage", (Jour. Amer. Chern. Soc., 34(1912), No. 11, pp. 1619-1625).

248. "The Silo and Its Construction", (N. D. Sta. Bul. 98, kp. 27, Figs. 11).

249. "Silage Analysis", (Canada Expt. Farms Rpt. 1912, pp. 146-147, 148-155) also (Wis. Sta. Circ. Inform. 42, pp. 110$)$.

250. "Sorghum Crops for Silage", (Kan. Sta. Circ.28, pp. 6)

251. "Corn Silage for Lambs", (Canada Expt. Farms. Rpts. 1912, pp. 380-408); for sheep, IN. Y. Dep't. Agri. Bul. 35, 1912, pp. 1056-1070). 252. "Corn Silage for Fattening Year-old steers", (Mo. Sta. Bul. 112, pp. 259-275, Figs. 5).

253. "Soiling and surmer Silage", (Mass. Bd. of Agri. Rpt. 1911, pp. 52-64).

254. "Mock or Dry Corn Silage", (Vt. Sta. Bul. 170, pp. 126,127 ).

255. "Modern Silage Methods", (Salem Ohio, 1913, rev., pp. 251, Figs. 371 . 
256. "Lactic Acid in Corn Silage", (Iowa Sta. Res. Bul. 10, $\mathrm{pp} .365-3781$.

257. "The Making and Feeding of Silage",(U. S. Dep't. Agri. Farmers' Bul. 556, pp. 24).

258. "Brief Notes on Modern Silage Construction"(Agri. Jour. Union, So. Africa, 5(1913), No. 5, pp. 699-7051.

259. "Silo Construction", (Hoara's Dairyman, 45(1913) No. 20, pp. 707-710, 712-714, 716-720,730, Figs. 41 ).

260. "Silos, Silage, and Silage Crops for Hawaii", (Hawaii Sta. Press. Bul. 40, pp. 30, Figs. 4). 261. "Stack System of Making Silage", (Jour. Agri. (New Zeal. ), 6(1913), No. 6, pp. 609-615).

262. "Report on Silage Tests", (Ann. Rpt. Nebr. Corr Improvers' Assoc. 3(1912), pp. 33-38). 263. "Comparison of Different Kinds of Silos", (Amer. Thresherman, 16(1913), No. 2, pp. 82-83). 264. "The Construction of Silos with stone and Brick", (Agri. Jour. Union So. Africa, 5, (1913), No. 4, pi. 335-545).

265. "Stare Silo Construction", (Dep't. Agri. Va. Dairy and Food Div. Bul. 24,(1913), pp. 26). 266. "Silo Construction in Nebraska", (Nebr. Sta. Bul. 138, pp. 961 . 
267. "Silage Analysis", (Ann. Rpt. Dep't. of Agri, and Stock (queensland), 1912-13, pp. 72, 73).

268. "Changes in Silage During Storage", (Rev. Econ. Internat. 10(1913), II No. 2, pp. 444-4591.

269. "Cost of Producing Silage Crops", (N. J. Stas. Rpt. 1912, pp. 173-193).

270. "Acidity in Silage and Method of Determination\%, (Jour. Amer. Chem. Soc. 35 (1913) No. 4, pp. 476-483).

271. "Feeding Silage", (Ann. Rpt. Ont. Com Growers' Assoc., 1911, pp. 341 .

272. "Soiling Crops vs. Silage for Dairy Cows in Summer", (wis. Sta. Bul. 235,(1914), pp. 3-16).

273. "Combined Silo and Water Tunk", (Cement Era, 11 (1913), No. 11, pp. 34, 35).

274. "Burned Clay Block Silos", (Brick and Clay Rec. 43, (1913), No. 8, pp. 780-788).

275. "Constructing a silo Roof of Concrete", (Builaing Age, 35(1913), No. 8, pp. 367-368).

276. "Ensilage and the Production of Milk and Beef During Winter Months", a Hendbook, (Dublin and London, 1913, pp. 53 ).

277. "Silo Facts from Missouri Farmers", (Mo. Bd. of Agri. Mo. Bul. Il(1913), No. 9, pp. 108 ).

278. "Silo and Silage Catechism", (s. C. Sta. Circ. 12, pp. 3-16). 
279. "Concrete Block Silos", (Jour. Dep't. Agri. Victoria, 11(1913), No. 9, pp. 570-573).

280. "Modern Silo Construction", (Iowa Sta. Bul. I4l, pp. 159-229).

281. "Pit Silo for Western Kansas", (Agri. Ed. (Kan. Agri. Col. ), 5(1913), No. 14, pp. 12, Figs. 2).

282. "Silo Construction and Service", (st. Paul, Minn. 1913, pp. 100, Figs. 31 ).

283. "Corn Silage and Mill Products for Steers", (S.D. Sta. Bul. 148(1914), pp. 332-343, Figs. 5).

284. "Analysis and Digestibility of Different Silage", (Jahresber. Landw. Kammer stettin, Prov. Pommern, 1912, pp. 37-42).

285. "Silage Crops for Oklahoma", (Okla. Sta. Circ. 34(1914), pp. 3-15, Fig. 1).

286. "Feeding Corn Silage to Farm Animals"(Iowa Sta. Circ. 6(1913), pp. 6).

287. "Silage for Ewes", (Mo. Sta. Bul. 117(1914), pp. 418-420).

288. "Clover and Corn Silage for Dairy Cows", (Mont. sta. Bul. 94(1913), pp. 33-54, Figs. 3 ).

289. "Silage for Fattening Cattle", (Penn. Dep't. Agri. Bul. 235, pp. 250, P1s. 33).

290. "Handling Silage", (Nebr. Sta. Bul. 145(1914), pp. 5-25, Figs. 19l. 
291. "Making and Feeding Silage", (U. S. Dep't. Agri. Farmers' Bul. 578, (1914), pp. 24, Figs. 6). 292. "Silos and Ensilage", (La. Sta. Bul. 143, (1914), pp. 20, Figs. 151 .

293. "Silo Building", (Ky. Sta. Ext. Circ. 18(1914), pp. 24, Figs. 8 ).

294. "The Effects of the Finsilage Process on the Soluability of Flots", (Jour. Indus, and Engin. Chem. 6(1914), No. 3, pp. 222-223; also No. 7 , pp. 605; also, No. 8, pp. 6951.

295. "The Effect of Ensilage Fermentation and Animal Digestion on the Soluability of Phosphoric Acid in Phosphate Rock", (Jour. Indus, and Fingin. Chem. 6(1914), No. 6, pp. 487-488)

296. "Silage vs. Cotton Seed Meal for Beef Cattle", (Tenn. Sta. Bul. 104(1914), pp. 77-107, Figs. 4). 297. "Forms for Concrete Silos", (Abs, in Concrete and Construct. Engin. 9(1914), No. 5, pp. 339-344)

298. "Concrete Silos", (Chicago, Pittsburg and Minneapolis, 1914, pp. 104, Figs. 76J.

299. "Four Types of Silos", (Okla. Sta. Circ. 33 (1914), pp. 16, Figs. 14).

300. "Homemade Silos", (U. S. Dep't. Agri. Farmers' Bul. 589, (1914), pp. 47, Figs. 37 ).

301. "Construoting and Filling Silos", (N. C. Sta. Circ. I(1913), pp. 8, Figs. 6). 
302. "The Tenneree Wooden-Hoop Silo", (Tenn. Sta. Bul. 105(1914), pp. 109-119, Figs. 5 ).

303. "How to Build a Gurler silo", (Mo. Sta. Circ. 67, (1914), pp. 247-257, Figs. 10).

304. "Silage Analysis", (Canada Exp. Farm Rpts. 1913, pp. 223-24l) also (N. D. Sta. Spec. Bul. 3(1914), No. 9, pp. 140-146).

395. "Bacteriological Researches on Forage Conservation in the silo", (Ann. 1st. Agri. (Milan), 5(19011904), pp. 97-100; 6(1904-1905), pp. 105-122, P1. 1; 7(1905-6), pp. 47-57; 8(1906-7), pp. 49-68; $9(1907-9)$, pp. 85-92; 10(1909-11), pp. 95-112; $11(1911-13)$, pp. 165-175).

306. "Cost of Raising S1lage Crops", (Canada Exp. Farms Bul. 75(1914), pp. 43) also (N. J. Sta. Rpts. 1913, pp. 391-417).

307. "Digestion and Metabolism of Steors when Placed on a Continuous Ration of silage", (Ga. Sta. Bul. 109(1914), pp. 145-158, Figs. 8).

308. "Fffect of silage Acida on Concrete", (Concrete Cement Age, 5(1914), No. 3, pp. 125).

309. "Steam Power vo. Electricity for Filling Silos", (Elect. World, 64(1914), No. 19, pp. 914, Figs. 3). 
310. "Silage for Horses and Mules", (Mo. Sta. Circ. 72(1914), pp. 29-32, Fig. 1) al so "For Feeding Ewes", (Mo. Sta. Bul. 120(1914), pp. 31-57).

311. "Value of Silage in a Winter Ration for the Breeding Flock", (N. H. Sta. Circ. 16(1914), pp. 3-16).

312. "Chemical Changes During Silage Formation", (Iowa Sta. Res. Bul. 16(1914), pp. 3-32; Jour.Amer. Chem. Soc. 36(1914), No. 11, pp. 2401-2413).

313. "Shock Corn for Silage", (Mo. Sta. Circ. 71(1914), pp. 25-28, Hig. 1).

314. "Silos and Silage", (Ga. Sta. Bul. 110(1914), pp. 163-190).

315. "Building a Pit Silo", (S. D. Sta. Bul. 154(1914), pp. 83-96).

316. "Ensilage Experiments with Lactic Acid Culture", (BI. Zuckerrubenbaw; 21(1914), Nos. 11, pp. 168-173; 13, pp. 201-202).

317. "A New Process of Preparing Potatoes for Acid Fnsilage with Pure Culture of Lactic Bacteria", (ztschr. Spiritusindus, 37(1914), No. 8, pp. 103. Fig. 1; Abs. in Internat. Inst. Agri. (Rome); Mo. Bul. Agri. Intel. and Plant Diseases, 5(1914), No. 5, pp. 693-694, Fig. 1).

316. "Inoculation of Ensiled Roots with Germ Culture", (ztschr. Ver. Dent. Zuckerindus; No. 703, (1914), II, pp. 668-671). 
319. "Silage Making and Feeding", (Colo. Sta. Bul. 200(1914), pp. 22-32, Fig. 1).

320. "Modern Silage Methods", (Salem, Ohio, The Silver Mfg. Co. 1914 ).

321. "The Finsiling of Beet Tops and Potatoes with Lactic Bacteria", (Landw. Uchnschs.Sachsen, 16 (1914), No. $26, \mathrm{pp} .231-232$; No. 12, pp. 106-107).

322. "Fnsiling Potatoes", (ztschr. Landw. Kammer Schlesien, 18(1914), Nos. 38, pp, 1485-1486; 39 pp. 1505-1506).

323. "Occurence of Methyl Alcohol in Corn Silage", (Jour. Amer. Chem. Soc. $36(1914)$, No. 10, pp. 2114-2118).

324. "Silage Spoiling in Motal Silog", (Okla. Sta. Bul. 101 (1914), pp. 83, Figs. 87).

325. "Corn Silage and Cotton Seed Hulls for Fattening Beef Cattle", (Bul. N. C. Dep't. of Agri. 25(1914), No. 8, pp. 5-28, Figs. 17).

326. "Corm Silage as Compared with Hulls for Fattening steers", (Miss. Sta. Bul. 167(1914), pp. 3-8).

327. "Worth and Uses of Silos and Silage", (quart.Rpt. Kans. Bd. Agri. 33(1914), No. 129, pp, 110-380). 328. "Construction of Vitrified Silos", (N. J. Sta. Rpt. (1913), pp. 334-344).

329. "Building Instructions for Concrete Silos", (Colo. sta. Bul. 200(1914), pp. 32-49) also"Pit silos", (Bul. 200, pp. 49-55). 
330. "The Missouri Silo", (Mo. Bd. of Agri. Mo. Bul. 12(1914), No. 8, pp. 39 ).

331. "Silos and Silage", (Ala. Sta. Circ. 26(1914), pp. 87-94, Figs. 31 .

332. "Silo Construction", (Ga. Sta. Bul. 110(1914), pp. 165-176, Figs. 81.

333. "Analysis of Gas from Silo", (Exp. Sta. Rec. Vol. $32(1915), \mathrm{pp} .679)$.

334. "Silo and Silage in Colorado", Colo. Sta. Bul. 200(1914), pp. 3-21, Figs. 8).

335. "The Wooden Hoop Silo", (West Va. Sta. Circ. 8(1914), pp. 4, Figs. 2).

336. "Silage Analysis": (Conn. State Sta. Rpt. 1914, Pt. 4, pp. 199-226).

337. "Ensiling Potatoes with a Lactic Acid Culture", (Illus. Landw. Ztg. 34(1914), No. 86, pp-737-738).

338. "Wheat Silage", (Wash. Sta. Popular Bul. 88(1915), pp. 4, Fig. 1 ).

339. "Corn Silage and Alfalfa Hay for Beef Production", (Nebr. Sta. Bul. 151(1915), pp. 43, Figs. 16), also (Ind. Sta. Bul. 178(1914), pp. 343-384).

340. "Bnsiling Feed Materials with the Aid of a Lactic Acid Bacteria Culture", (Jahresber, Ver. Angew. Bat., 11(1913), No. 2, pp. 142-167). 
341. "Studies on the Preparation of Silage", (Bol. Min. Agri. Indus. e Com. (Rome), Ser. C, 12(1913), No. 8-12, pp. 87-103; Abs. in Internat. Agri. (Rome), Mo. Bul. Agri. Intel. and Plant Diseases, 5(1914), No. 12, pp. 1625-1626).

342. "Silage and Grain for Steers", (S.D. Sta. Bul. 160(1915), pp. 197-223, Figs. 10).

343. "Silage Feeding", (Okla. Sta. Circ. 36(1914), pp. $2-8)$.

344. "The Silo and Its Use", (Mo. Sta. Bul. 133(1915), pp. 3-19, Figs. 5)

345. "Concrete Silos", (Assoc. Amer. Portland Cement Mfg. Bul. 21, rev. (1915), pp. 64, Figs. 36).

346. "Methods of Costs in Constructing a Combined Concrete silo and Water Tank", (Concrete Cement Age, 6(1915), No. 3, pp. 162-164, and No. 6, pp. 301-302).

347. "Filling Silos", (Kans. Sta. Circ. 53(1915), pp. 8, Figs. 3).

348. "The Associative Digestibility of Corn Silage, Cotton seed Meal and Starch in a Steer's Ration", (Ga. Sta. Bul. 115(1915), pp. 269-295, Figs. 7)

349. "Construction of Silos", (W. Va. Bul. 129, pp. 187195, P1s. 2). 
350. "Cooperative Silo Building", (Country Gentleman, 76, (1911), No. 3027, pp. 110).

351. "Silo Construction", (Jour. Dep't. Agri. Victoria, 9(1911), No. 7, pp. 492-503; 8, pp. 566-576).

352. "Gurler Silo", (Mo. Sta. Circ. 48, pp. 107-114) and "Concrete Silo", Cir. 49, pp. 115-122).

353. "The Iowa Silo", (Iowa Sta. Bul. 117, pp. 196-266).

354. "Practical Silo Construction", (N.Y. 1911, pp. 69).

355. "Cost of Filling a Silo", (U. S. Dep't. of Agri. Farmers' Bul. 292, pp. 15, Figs. 3).

356. "Filling a silo and the cost of silage", (Hoard's Dairyman, 42(1911), No. 28, pp. 858).

357. "Reinforced Brick Silo", (U. S. Dep't. of Agri. Farmers' Bul. 457, pp. 24, Fig. 1).

358. "How to build a stave Silo", (U. S. Dep't. of Agri. Bureau of Animal Industry, Circ. 136, pp. 18, Figs. 18$)$.

359. "The Kind of Wood for a Silo", (Breeder's Gazette, 59, 1911, No. pp. 1002 ).

360. "Experiments of Ensilage", (Rothamstead Exp. Sta. or Memoirs, Vol. 4 ).

361. "Silage Investigations", (Mo. Exp. Sta. Res. Bul. No. 22 ). 


\section{ACKNOWLEDGEIENT}

The writer wishes to acknowledge his indebtedness to C. H. Eckels, Professor of Dairy Husbandry, University of Missouri, for his helpful suggestions in the preparation of this thesis. 


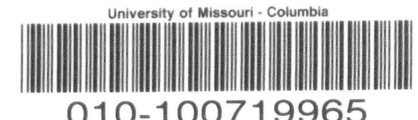

\subsection{M7I \\ $X D 251$}

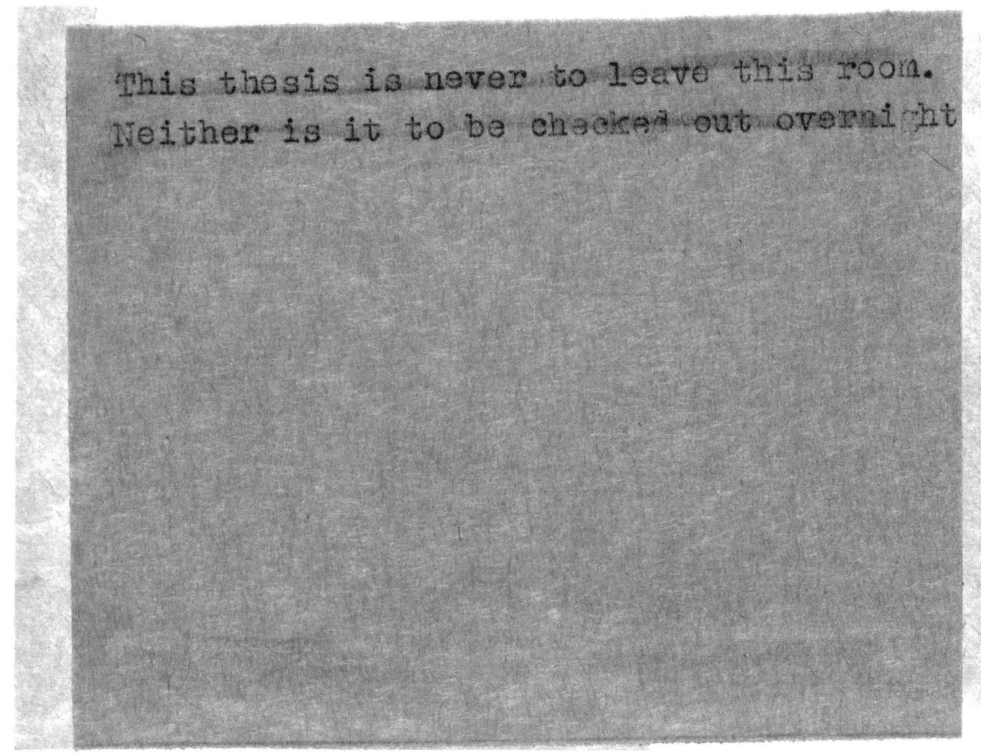


MU Libraries

Darne111916.txt

University of Missouri--Columbia

MU Theses and Dissertations (Pre-1920)

Local identifier

Capture information

Date captured

Scanner manufacturer

Scanner mode1

Scanning system software

optical resolution

Color settings

File types

Source information

Format

Content type

Source ID

Notes
Darne 111916

2016-04-25

Zeutsche1

OS 15000

Omniscan v.12.4 SR4 (1947) 64-bit

$600 \mathrm{dp} i$

grayscale, 8 bit

tiff

Book

Text [with image]

010-100719965

Pages typed and single-sided.

Title page has signature and perforated property stamp.

Photograph is pasted in on plate 1

Two blank pages at end not scanned.

Inside back cover has stamp, barcode, and cal1 number

Tiff compressed with LZW before conversion to pdf Adobe Photoshop CS5

$600 \mathrm{dp} i$

Grayscale

pdf

Grayscale pages cropped, canvassed, and brightened Image scanned in grayscale and not brightened

B 1 ank pages removed. 